\title{
A Study of China's Explosive Growth in the Plug-in Electric Vehicle Market
}

Approved for public release. Distribution is unlimited.

\section{Shiqi Ou \\ Zhenhong Lin \\ Zhixin Wu \\ Jihu Zheng \\ Renzhi Lyu \\ Steven Przesmitzki \\ Xin $\mathrm{He}$}

January 2017 


\title{
DOCUMENT AVAILABILITY
}

Reports produced after January 1, 1996, are generally available free via US Department of Energy (DOE) SciTech Connect.

Website http://www.osti.gov/scitech/

Reports produced before January 1, 1996, may be purchased by members of the public from the following source:

\author{
National Technical Information Service \\ 5285 Port Royal Road \\ Springfield, VA 22161 \\ Telephone 703-605-6000 (1-800-553-6847) \\ TDD 703-487-4639 \\ Fax 703-605-6900 \\ E-mail info@ntis.gov \\ Website http://www.ntis.gov/help/ordermethods.aspx
}

Reports are available to DOE employees, DOE contractors, Energy Technology Data Exchange representatives, and International Nuclear Information System representatives from the following source:

Office of Scientific and Technical Information

PO Box 62

Oak Ridge, TN 37831

Telephone 865-576-8401

Fax 865-576-5728

E-mail reports@osti.gov

Website http://www.osti.gov/contact.html

This report was prepared as an account of work sponsored by an agency of the United States Government. Neither the United States Government nor any agency thereof, nor any of their employees, makes any warranty, express or implied, or assumes any legal liability or responsibility for the accuracy, completeness, or usefulness of any information, apparatus, product, or process disclosed, or represents that its use would not infringe privately owned rights. Reference herein to any specific commercial product, process, or service by trade name, trademark, manufacturer, or otherwise, does not necessarily constitute or imply its endorsement, recommendation, or favoring by the United States Government or any agency thereof. The views and opinions of authors expressed herein do not necessarily state or reflect those of the United States Government or any agency thereof. 
Energy and Transportation Science Division

\title{
A Study of China's Explosive Growth in the Plug-in Electric Vehicle Market
}

\author{
Shiqi Ou \\ Oak Ridge National Laboratory \\ National Transportation Research Center \\ 2360 Cherahala Boulevard \\ Knoxville, TN 37932 USA \\ Zhenhong Lin* \\ Oak Ridge National Laboratory \\ National Transportation Research Center \\ 2360 Cherahala Boulevard \\ Knoxville, TN 37932 USA
}

\section{Zhixin Wu}

China Automotive Technology and Research Center

Dongli District, Tianjin 300300, China

\section{Jihu Zheng}

China Automotive Technology and Research Center

Dongli District, Tianjin 300300, China

\section{Renzhi Lyu}

China Automotive Technology and Research Center

Dongli District, Tianjin 300300, China

\section{Steven Przesmitzki}

Aramco Services Company

46535 Peary Ct, Novi, MI 48377 USA

Xin He

Aramco Services Company

46535 Peary Ct, Novi, MI 48377 USA

Date Published: January 2017

Prepared by

OAK RIDGE NATIONAL LABORATORY

Oak Ridge, TN 37831-6283

managed by

UT-BATTELLE, LLC

for the

US DEPARTMENT OF ENERGY

under contract DE-AC05-00OR22725 



\section{CONTENTS}

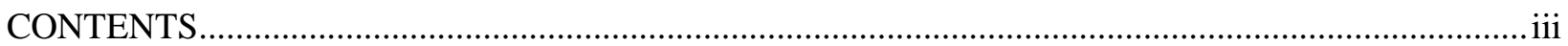

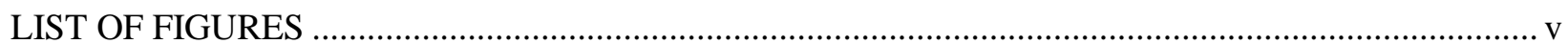

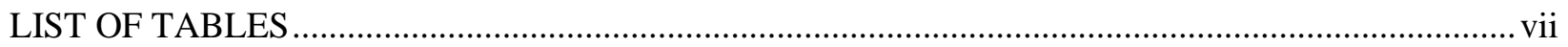

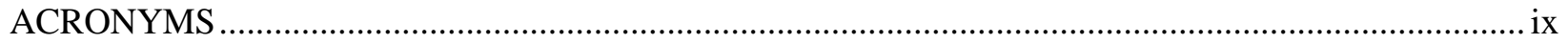

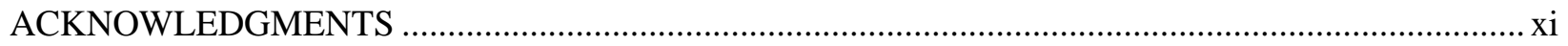

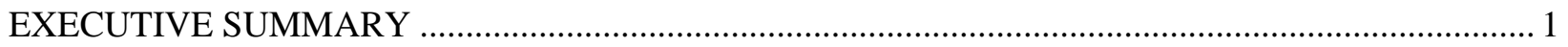

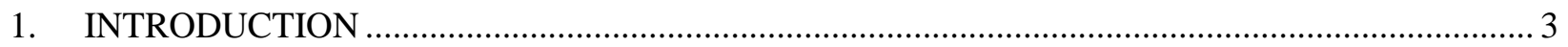

2. CHINA'S PLUG-IN ELECTRIC VEHICLE MARKET …..................................................... 5

2.1 PLUG-IN ELECTRIC VEHICLE CLASSIFICATIONS IN CHINA …............................. 5

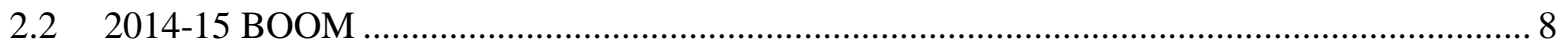

2.3 FEATURES OF PLUG-IN ELECTRIC VEHICLE SALES …........................................ 12

2.4 MARKET COMPETITION AND INDUSTRY ORGANIZATION …................................. 14

2.5 PLUG-IN ELECTRIC VEHICLE MARKET COMPARISON OF CHINA AND THE

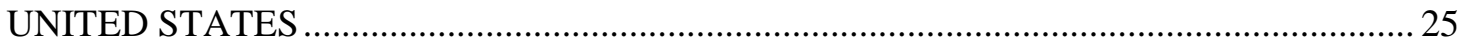

2.6 MICRO EVS: MOST WELCOMED PLUG-IN ELECTRIC VEHICLES ...........................29

2.7 MULTINATIONAL INVESTMENTS IN CHINA'S PLUG-IN ELECTRIC VEHICLE

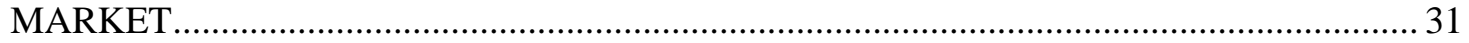

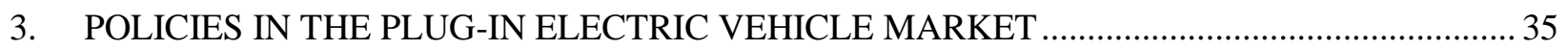

3.1 POLICIES OF THE CENTRAL GOVERNMENT IN 2012-2015 …............................... 35

3.1.1 Government Subsidies in Light-Duty PEVs (passenger plug-in electric cars) ............. 37

3.1.2 Government Subsidies in Heavy-Duty PEVs (plug-in electric buses).......................... 38

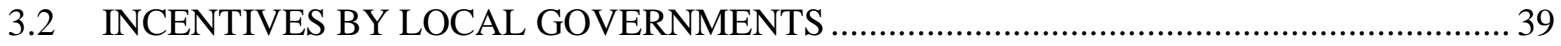

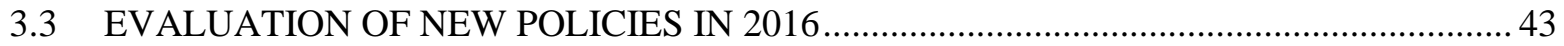

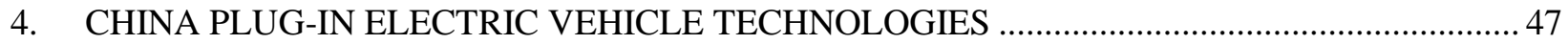

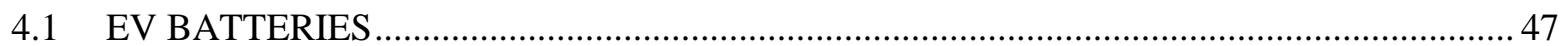

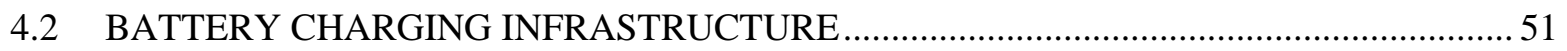

4.2.1 Comparison of Public EV Charging Outlets .......................................................... 51

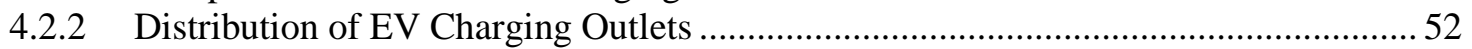

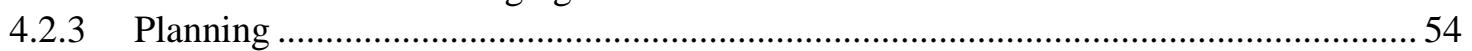

4.3 OTHER ELECTRIFIED VEHICLE TECHNOLOGIES .................................................. 55

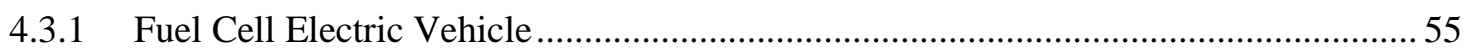

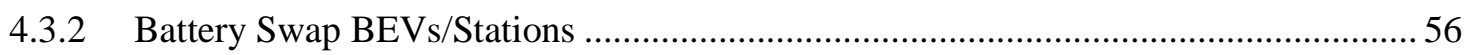

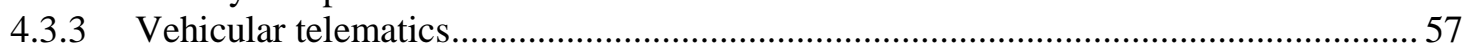

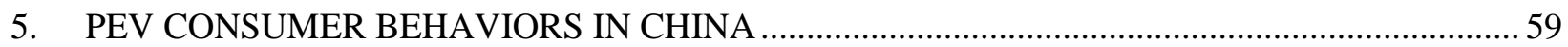

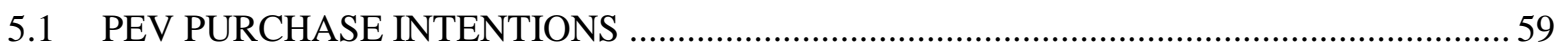

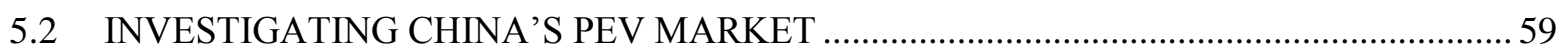

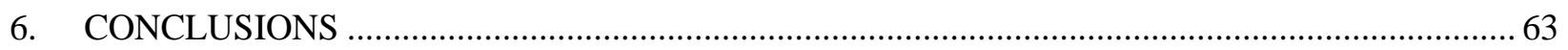

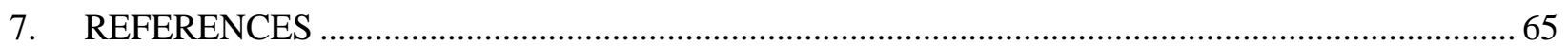

Appendix A. APPENDIX A. MAJOR NATIONAL POLICIES OR EVENTS IN PEV INDUSTRY,

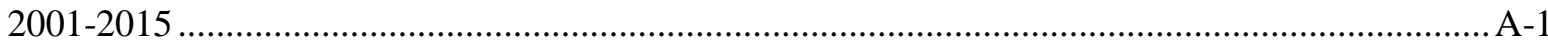




\section{LIST OF FIGURES}

Fig. 1. Plug-in electric vehicle productions in China, 2009-2015 ....................................................... 1

Fig. 2. Plug-in electric vehicle production and market share in China, 2009-2016 ................................. 5

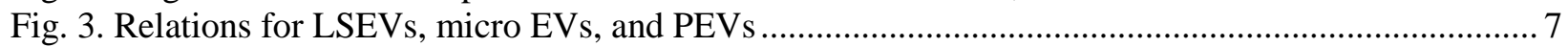

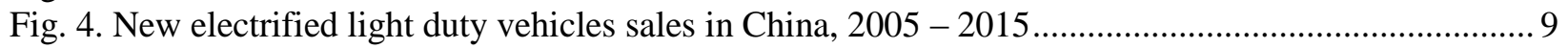

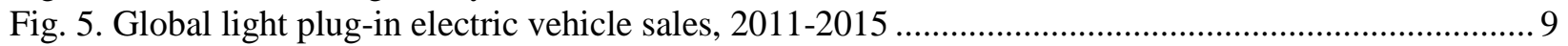

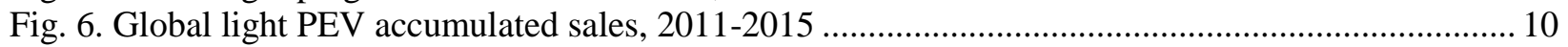

Fig. 7. Distribution of vehicle types in the Chinese BEV sales market for 2014 and 2015.................... 11

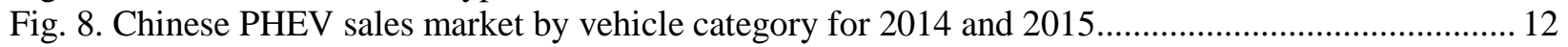

Fig. 9. New Plug-in Electric Vehicle Monthly Sales in China, 2013 - 2015 (2)..................................... 13

Fig. 10. Total vehicle monthly sales in China, 2011 - 2015 (2) ............................................................ 13

Fig. 11. a) New light PEV market share by models, 2015; b) new PEV market share by models, 2015 15

Fig. 12. Sales and prices for 10 best-selling PEVs (basic model) in China, 2015 ................................ 16

Fig. 13. Price range distribution of private purchase PEVs in China, 2015 (2) ...................................... 17

Fig. 14. a) China new vehicle market share by manufacturer, 2015; b) China new PEV market

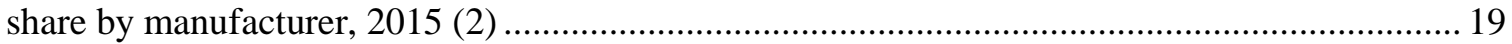

Fig. 15. Twenty largest PEV manufacturers by sales in China's market, 2015 (2) ............................... 20

Fig. 16. a) Model units of the domestic passenger PEVs by technology type in 2016-2020; b) model units of the domestic passenger PEVs by vehicle size in 2016-2020 (2)......................... 21

Fig. 17. The headquarter locations of primary automakers (top 15 by sales in 2015) ............................. 24

Fig. 18. Headquarter locations of primary PEV makers (Top 15 by sales in 2015) ................................ 24

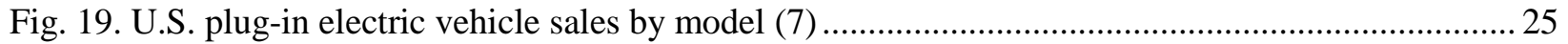

Fig. 20. a) Sales \& prices for ten best-selling PEV models in the U.S. market, 2015 (7); b) U.S.

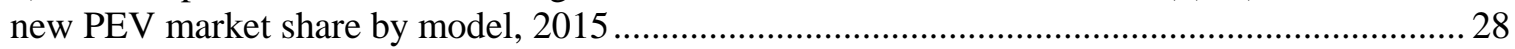

Fig. 21. a) U.S. new PEV market share by manufacturer, 2015 (7); b) U.S. new passenger car

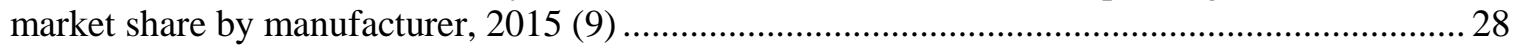

Fig. 22. Passenger plug-in electric vehicles sales by classifications, 2014 and 2015 (2) ........................ 29

Fig. 23. LSEV production from twenty major LSEV makers in Shandong province, 2011-2014 (10) 31

Fig. 24. a) Model units of the imported passenger PEVs by technology type in 2016-2020; b) model units of the imported passenger PEVs by vehicle size in 2016-2020 (2)........................... 33

Fig. 25. Prices for ten best-selling PEVs (basic model) in China, 2015, (2) ......................................... 38

Fig. 26. PEV sales and government goals in major cities and provinces, 2013-2015 (2)...................... 41

Fig. 27. City types distribution of sold out PEVs to private consumers in China (2); .......................... 42

Fig. 28. Comparison with GDP per capita and the government PEV sales goal accomplished

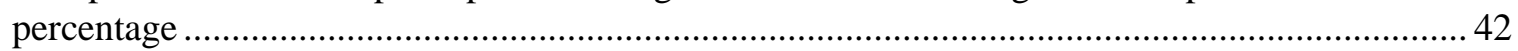

Fig. 29. CAFE targets (MPG) for passenger vehicles, 2010-2025 (2)(13) ............................................ 45

Fig. 30. Largest global EV battery manufacturers by sales and market share, 2014-2015 ..................... 48

Fig. 31. a) China's PEV industry investment (billion CNY), Jan 2014-Jun 2015; b) China's EV battery (GWh) production, 2010-2015 (2).

Fig. 32. a) Chinese EV battery suppliers by ranked by production (GWh) in China, 2012-2015

(2); b) EV battery suppliers market shares by number of PEVs installed in China, 2015 ............ 49

Fig. 33. Installation of EV batteries by type (GWh) in China's PEV market, 2010-2015 .......................50

Fig. 34. Numbers of non-home charging outlets in China, U.S., and Japan (2)(7)............................... 51

Fig. 35. Non-home charging ratio in China, the U.S., and Japan ......................................................52

Fig. 36. Number of PEVs and charging outlets in China, 2011-2015 (2) ............................................5 52

Fig. 37. Distribution characteristics of charging outlets in China, 2015 ...............................................53

Fig. 38. Number of EV charging outlets in major cities in China, 2015 ................................................5 53 
Fig. 39. Plans for constructing a) charging stations and b) charging outlets in China by 2020 (2) ........... 55

Fig. 40. Chinese consumer demands in vehicular telematics system.................................................... 57 


\section{LIST OF TABLES}

Table 1. Vehicle classifications in Chinese vehicle market ............................................................... 6

Table 2. Ten best-selling PEV models in Chinese market, 2015 (2) ...................................................... 15

Table 3. Ten best-selling plug-in electric vehicle models in the U.S., 2015 (7) ................................... 26

Table 4. Primary Government Guidelines in the PEV Industry......................................................... 35

Table 5. Central government subsidies for electrified passenger cars, 2013-2015 '................................ 37

Table 6. Central government subsidies for electrified buses, 2013-2015 '............................................ 39

Table 7. Central government subsidies for electrified passenger cars, 2016-2020 (Partial)..................... 43

Table 8. Specific energy density goals of EV batteries in major countries (2) ........................................47 


\section{ACRONYMS}

\begin{tabular}{|c|c|}
\hline AFV & Alternative Fuel Vehicle \\
\hline BAIC & Beijing Automotive Industry Holding Co., Ltd. \\
\hline BEV & Battery Electric Vehicle \\
\hline BSS & Battery Swap Service \\
\hline CAFC & Cooperate Average Fuel Consumption \\
\hline CAFE & Cooperate Average Fuel Economy \\
\hline CATARC & China Automotive Technology and Research Center \\
\hline CNY & Chinese Yuan \\
\hline DC & Direct Current \\
\hline EPA & Environmental Protection Agency \\
\hline EREV & Extended Range Electric Vehicle \\
\hline EV & Electric Vehicle \\
\hline FCEV & Fuel Cell Electric Vehicle \\
\hline GDP & Gross Domestic Product \\
\hline GHG & Greenhouse Gas \\
\hline GM & General Motor \\
\hline HEV & Hybrid Electric Vehicle \\
\hline $\mathrm{HOV}$ & High Occupancy Vehicle \\
\hline iCET & Innovation Center for Energy and Transportation \\
\hline IT & Information Technology \\
\hline LFP & Lithium Ferro Phosphate Battery \\
\hline LHV & Low Heat Value \\
\hline LSEV & Low Speed Electric Vehicle \\
\hline MA3T & Modeling the Market Acceptance of Advanced Automotive Technologies \\
\hline MIIT & Ministry of Industry and Information Technology, P.R. China \\
\hline $\mathrm{mph}$ & Miles per hour \\
\hline MPV & Multi-purpose Vehicle \\
\hline MPG & Miles per Gallon \\
\hline MSRP & Manufacturer's Suggested Retail Price \\
\hline NCM & Lithium Nickel Cobalt Manganese Battery \\
\hline NEA & National Energy Administration, P.R. China \\
\hline NEV & New Energy Vehicle \\
\hline OEM & Original Equipment Manufacturer \\
\hline ORNL & Oak Ridge National Laboratory \\
\hline PEV & Plug-in Electric Vehicle \\
\hline PHEV & Plug-in Hybrid Electric Vehicle \\
\hline Q1 & First Quarter \\
\hline R\&D & Research \& Development \\
\hline SAIC & Shanghai Automotive Industry Holding Co., Ltd. \\
\hline SGCC & State Grid Corporation of China \\
\hline SUV & Sports Utility Vehicle \\
\hline U.S. & United States \\
\hline USD & US Dollar \\
\hline VC & Venture Capital \\
\hline VW & Volkswagen \\
\hline ZEV & Zero Emission Vehicle \\
\hline
\end{tabular}




\section{ACKNOWLEDGMENTS}

The authors would like to thank Aramco Service Company for the generous financial support for this study. The authors are solely responsible for content expressed. 


\section{EXECUTIVE SUMMARY}

The year 2015 marks a turning point in China's plug-in electric vehicle (PEV) or new energy vehicle $(\mathrm{NEV})^{*}$ industry, with an explosive growth in both productions and sales, following the gloomy period of 2009-2012. The PEV production in 2015 reached a record level of nearly 380,000 units, a $352 \%$ increase from 2014, making China the largest PEV market in the world. For the potential implications on energy and the environment, it is worth studying the driving forces of China's PEV market and understanding its future trajectory and dynamics.

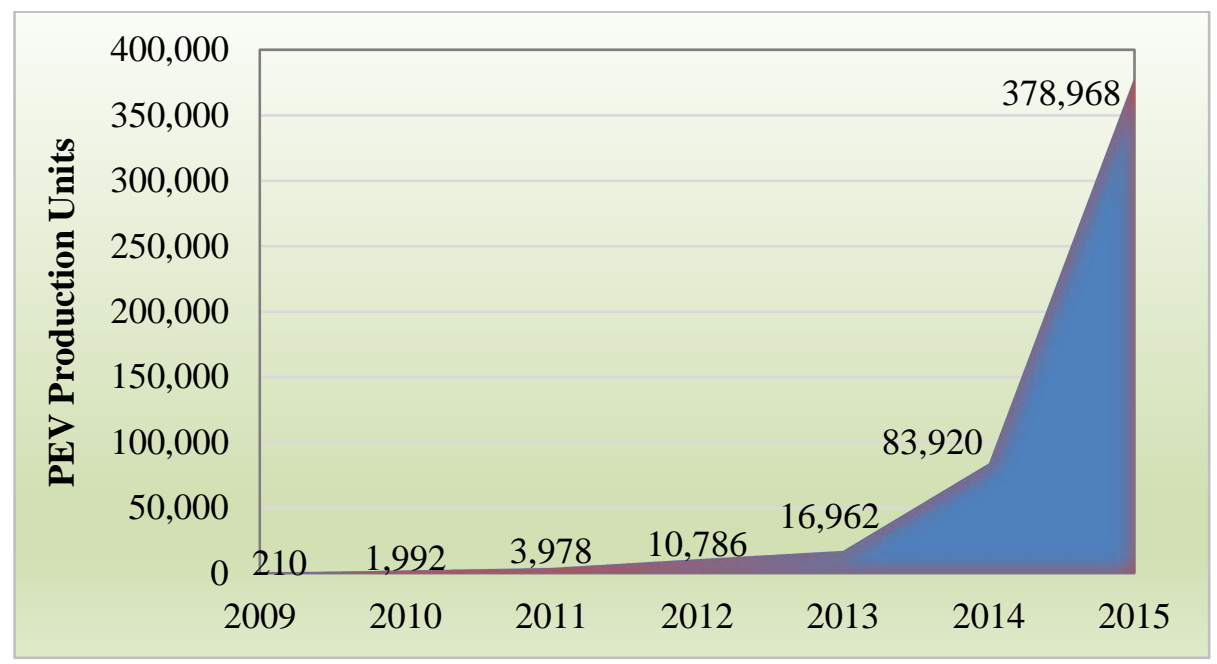

Fig. 1. Plug-in electric vehicle productions in China, 2009-2015

The key findings of this report are listed in the following.

- Though controversial, the government monetary incentives have played a significant role to impel China to be the largest light PEV (191,100 units) market in the world.

- Chinese vehicle buyers appear more price sensitive on PEVs. Inexpensive low-cost micro electric vehicles are the most popular vehicle model in China's PEV market (38.9\% of the PEV market in 2015). In contrast, the premium or luxury vehicles are more popular in the gasoline vehicle segment. In fact, China is expected to be the largest premium car market in 2016.

- The PEV sales growth is primarily possible because of the young domestic private-owned auto manufacturers, which are mostly located in south China. Top-tier conventional vehicle automakers in China appear to be less proactive in the PEV market, based on market shares. This is in clear contrast to the U.S. market, where major automakers are generally the primary players in the PEV market.

- The PEVs produced by the domestic automakers are concentrated in the low-end market segment, while the high-end vehicle segment is dominated by the foreign brands. At present, the substantial market growth and government subsidies afford the domestic entrants to quickly gain profits in the low-end segment.

\footnotetext{
${ }^{*} \mathrm{NEVs}$ in China include battery electric vehicles (BEVs/EVs), plug-in hybrid electric vehicles (PHEVs), extended range electric vehicles (EREVs), and fuel cell electric vehicles (FCEVs). Very few fuel cell electric vehicles (FCEV) are currently commercialized in China, so NEVs are regarded as plug-in electric vehicles (PEVs), a concept widely used in the United States and other countries. In this report, PEV is in terms of the new energy vehicle (NEV) unless explicitly indicated otherwise.
} 
- The PEV consumers in China are very sensitive to the vehicle price, thus prefer the PEVs with cheaper prices after government subsidies, and care less about the driving quality and comfort. In contrast, most PEV consumers in the United States (U.S.) have higher incomes, view the PEVs as a high-status symbol, and care less about the vehicle prices, and therefore welcome the premium PEVs more in the U.S.

- The PEV financial subsidies by the Chinese government are divided into three stages based on the strategic directions and policies. In 2009-2012, government incentives concentrated on the public fleet vehicles, while excluding the individual consumers from the subsidies in most cities. In 20132015, comprehensive central/local government incentives were extended to all vehicle purchasers including the individual buyers in most cities, which was conducive to the phenomenal growth of the PEV sales. For years 2016 to 2020, monetary incentives are being phased out and will be substituted by other non-monetary incentives (such as the standards for Chinese Cooperate Average Fuel Consumption and New Energy Vehicle Credits) for the sustainable development of the PEV market. The PEV subsidy fraud has drawn attention by the central government, which prompts the government to be more prudent about monetary incentives.

- With the advantage of high acceptance in the PEV market and integrated EV charging infrastructure, the region with better economic development brings a more aggressive PEV roll-out plan to the municipalities who are more willing to solve the local urban pollution while keeping the automotive market in sustainable growth.

- On the one hand, the local automakers are offered abundant subsidies from the Chinese government to those who intend to help the Chinese automotive industry seize the industrial upgrading opportunity to transform its manufacturing sector, and they have taken most shares of the PEV market. On the other hand, facing the trade barriers, the foreign automakers have dominated the premium PEV sales in China, although their total market shares in the PEV market are much less than the domestic automakers.

- In diverse selectable alternative fuel vehicle technologies, China has put its focus on the PEV technologies for the technological modernization in the automotive industry; the research and development in fuel cell vehicle technologies in China is less competitive compared with other countries such as Japan and the U.S.

- With the demand of batteries from the PEV automakers, the Chinese EV battery industry is aggressively expanding. It has risks in excessive production capacity, and faces the challenges from the competitors from Japan and South Korea. 


\section{INTRODUCTION}

Rapid motorization in China is believed to have contributed to many social and environmental problems (congestion, urban pollution, energy and greenhouse gases (GHG)), to which plug-in electric vehicles (PEVs) are viewed as a long-term solution, especially for air pollution in highly congested urban areas (1). The China central government started to promote the PEVs in 2001 with research and development (R\&D) investments in the National High Tech R\&D Program (863 major scientific and technological projects) in the government's Tenth Five-Year Plan (2001-2005). In 2006, the new energy vehicle (NEV) promotion strategic plan was explicitly included into government Eleventh Five-Year Plan (2006-2010). In 2009, the “Ten Cities - Thousand Vehicles Demonstration Program” (十城千辆工程) was launched by the central government with local governments investments as well. Since then, the institutional environment for the PEV industry has been increasingly favorable, evidenced by frequent high-level official statements, major policy implementations, massive governmental and industrial investments, and generous purchase and adoption incentives, all summarized in the Appendix A. As a result, after slow market penetration in the first several years (2009 -2012), the PEV market in China began to have explosive growth after year 2013. In 2015, China became the world's largest light PEV market at an annual sales record of 191,000 units, followed by Western Europe with 184,500 units, then by the U.S. with 115,262 units*.

With the phenomenal growth of the PEV sales in China, several questions are of interests: what are the features of the Chinese PEV market and technologies compared with other major vehicle markets around the world, especially the U.S.? How to understand the Chinese consumer behavior toward PEVs? Has the PEV sales increase been driven entirely by the Chinese government? How will the plug-in electric vehicle policy circumstance in China evolve and how will the PEV demand in China respond? And last but not the least, what can we learn from the China's plug-in electric vehicle experiences to inform transportation energy policies both in China and other countries?

This report uses probably the most up-to-date information to describe the PEV market in China and attempts to contribute to a better understanding of the driving forces, barriers and prospects. The first chapter covers key market information, including key sales statistics in 2015 and comparisons of the bestselling PEV models and investment activities. This chapter depicts a full picture of the PEV industry in China and discusses the features of China's PEV market. The second chapter describes the Chinese government's major policies/incentives in recent years and the relations between economic developments and PEV sales. The influence of new policies/incentives on the prospective of the PEV market in the next few years is also discussed in this chapter. The third chapter focuses on the development of vehicle technologies in China, including electric vehicle (EV) batteries, charging infrastructure and related technologies such as the battery swapping stations and FCEVs in China, and the technological comparisons with other major countries. The next chapter reviews the literature that described the Chinese consumer behaviors and preferences in PEV purchasing and discussed their methodologies and conclusions. The last chapter gives the conclusions and the future studies in the Chinese PEV market.

\footnotetext{
* Source: http://energy.gov/eere/vehicles/fact-918-march-28-2016-global-plug-light-vehicle-sales-increased-about-80-2015 Data compiled by Argonne National Laboratory, Argonne, IL, February 2016.
} 
This report is a result of collaboration between the Oak Ridge National Laboratory (ORNL) and the China Automotive Technology and Research Center (CATARC). Most Chinese PEV market statistics are provided by CATARC and some are from the public information by the China Association of Automobile Manufacturers or the National Bureau of Statistics. For comparison purposes, U.S. automotive industry statistics from the Alternative Fuels Data Center of the U.S. Department of Energy are also analyzed in this report. All other reference information (research/technical publications, government legislations and announcements, news journals, industrial presentations or reports) has been listed in the footnotes and references. The dollar values mentioned in this report use 2015 prices. The 2015 yearly average currency exchange rate of \$1.0 U.S. Dollar (USD) = ¥ 6.489 Chinese Yuan (CNY) was used in the report*.

* Source from the U.S. Internal Revenue Service "Yearly average currency exchange rates", https://www.irs.gov/individuals/international-taxpayers/yearly-average-currency-exchange-rates (visited in September 2016) 


\section{CHINA'S PLUG-IN ELECTRIC VEHICLE MARKET}

China's PEV market had an explosive growth in year 2014, and even accelerated in year 2015. According to the statistics by the Automotive Data Center of CATARC*, the PEV sales and production in 2015 reached a record high of 343,675 and 378,968 respectively, about 4.5 times of the 2014 level (Fig. 2) ${ }^{\dagger}$. The PEV fleets on the road have reached 496,816 units from year 2009 to 2015 (2). The PEV sales share in the vehicle market has increased from $0.26 \%$ in 2014 to $1.40 \%$ in 2015, shown in Fig. 2. The explosive growth of the China PEV market has potential implications on energy, environment and trade, and thus calls for a better understanding of the underlying forces.

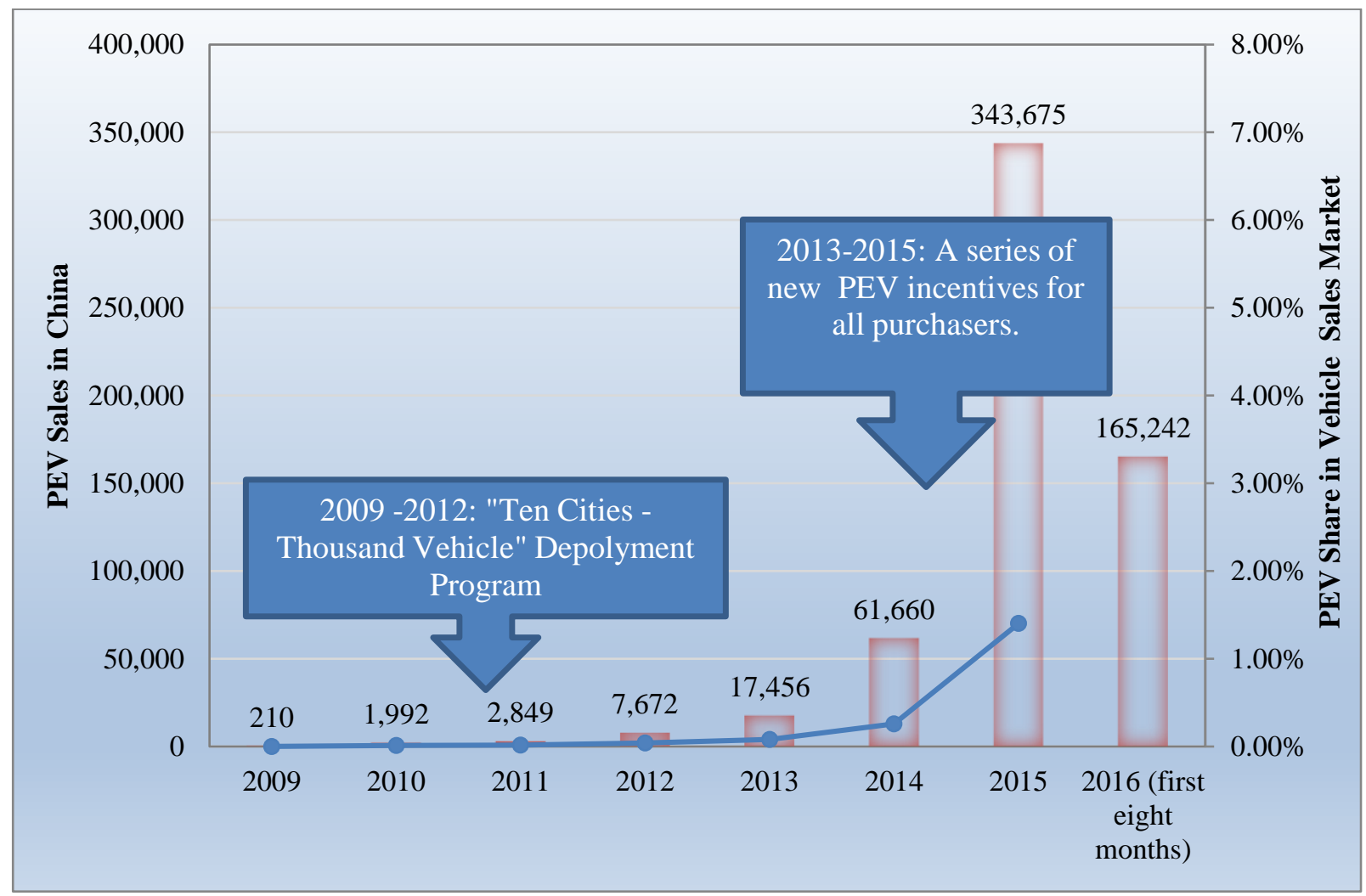

Fig. 2. Plug-in electric vehicle production and market share in China, 2009-2016

\subsection{PLUG-IN ELECTRIC VEHICLE CLASSIFICATIONS IN CHINA}

By definition, PEVs, a widely-used concept in the U.S., include battery electric vehicles (BEVs) and plug-in hybrid electric vehicles ([PHEVs], the extended ranged EVs are regarded as PHEVs in this report). The more popular concept used in China is NEV, which include PEVs and fuel cell electric vehicles (FCEVs). No FCEVs have been commercialized in China yet, making NEV currently equivalent to PEV. For communication convenience, the concept of PEVs is used throughout the report.

The Chinese PEV market should be analyzed in the Chinese vehicle classification system, which is complicated and very different from the United States. The official classification standard in the Chinese

\footnotetext{
* The statistics by CATARC are based on the vehicle registration of the local government Vehicle Administration Office.

$\dagger$ These statistical data exclude the imported PEVs.
} 
automotive industry is the Chinese national standard - GB/T3730.1-2001*, which classifies passenger vehicles into 11 models (such as sedan, convertible saloon, hatchback etc.) based on the vehicle purpose, doors, body style and seats, and yet, is rarely used by the industry and researchers for the positioning of a vehicle in the market place. The Chinese automotive industry has generally accepted the terminologies in the Europe market segmentation ${ }^{\dagger}$ for passenger cars, which defines the classes of passenger cars with English letters: A00, A0, A, B, C, D, E, F etc. (3) Nevertheless, the Chinese automotive industry has no concordant criteria for the passenger car classifications. The OEMs (Original Equipment Manufacturers) in China classify their car models based on various criteria, such as wheelbases, engine sizes, vehicle weights, car interior volumes, or vehicle market positions. Therefore, the passenger car classification in China is ambiguous without unified standards. In this report, the vehicle model classes are supplied by CATARC who has its own method to differentiate car segments. There are three criteria used by CATARC: wheel bases, engine displacement, and vehicle interior volumes.

According to the classifications by the 40 CFR 600.315-82 classes of comparable automobiles by the U.S. Environmental Protection Agency (EPA) ${ }^{\ddagger}$, and in general terms the American passenger vehicle market, the vehicles (especially the sedans) are segmented into Minicompact, Subcompact, Compact, Mid-size, Large-size. In order to associate the ambiguous Chinese common classification system with the U.S. EPA classifications, this report investigated and compared the classes of the top selling vehicle models in both Chinese and U.S. markets. For example, one of the most popular cars, the Toyota Camry, is classified by EPA as a mid-size car in the U.S. ${ }^{\S}$, and is generally treated as Class B in the Chinese automotive industry"*, thus it is deemed that the Class B is equal to the "Mid-size car." Although the comparison is not totally compatible, this offers the outsiders a method to visualize the Chinese vehicle classifications. Table 1 summarizes the major vehicle classes used in this report.

Table 1. Vehicle classifications in Chinese vehicle market

\begin{tabular}{|c|c|c|c|c|}
\hline \multicolumn{3}{|c|}{ Class } & Name & \multirow{2}{*}{$\begin{array}{c}\text { Example } \\
\text { Smart }\end{array}$} \\
\hline \multirow{7}{*}{ Passenger Vehicle } & \multirow{5}{*}{ Sedan/Car } & $\mathrm{A} 00$ & Minicompact & \\
\hline & & A0 & Subcompact & Honda fit \\
\hline & & A & Compact & Toyota Corolla \\
\hline & & B & Mid-size & Toyota Camry \\
\hline & & $\mathrm{C}$ & Large-size car & Audi A8 L \\
\hline & \multicolumn{2}{|c|}{ SUV } & Sports Utility Vehicle & - \\
\hline & \multicolumn{2}{|c|}{ MPV } & Multi-Purpose Vehicle & - \\
\hline \multirow{3}{*}{ Commercial vehicle } & \multicolumn{2}{|c|}{ Bus } & - & - \\
\hline & \multicolumn{2}{|c|}{ Truck } & - & - \\
\hline & \multicolumn{2}{|c|}{ Special vehicle ${ }^{\mathrm{a}}$} & - & - \\
\hline
\end{tabular}

\footnotetext{
${ }^{*}$ Source by http://www.camra.org.cn/fuwu/standard/GB-T\%203730.1-2001.pdf. (in Chinese)

$\dagger$ Source by http://ec.europa.eu/competition/mergers/cases/decisions/m1406_en.pdf. (in Chinese)

* Source by https://www.gpo.gov/fdsys/pkg/CFR-1996-title40-vol16/pdf/CFR-1996-title40-vol16-sec600-315.pdf. (in Chinese)

$\S 2017$ Camry Product Information. http://toyotanews.pressroom.toyota.com/releases/2017-toyota-camry-product-specs.htm

${ }^{* * *}$ Vehicle Classifications. Baidu Baike. http://baike.baidu.com/view/556684.htm (in Chinese)
} 
This report covers only the officially recognized PEVs, that is, those models listed in the Announcement of Vehicle Manufacturing Enterprises and Vehicle Products (车辆生产企业及产品公告) (hereinafter referred to as the Announcement) and therefore those models are included in the PEV statistics by CATARC. Noticeably, imported vehicles are excluded by the Announcement, thus the imported PEVs are not counted into PEV statistics by CATARC. Nevertheless, the imported PEV sales in China will be discussed separately.

Some PEV models included in the Announcement are eligible for government subsidies if they were approved for inclusion in the Catalogue of Recommended Models for the New Energy Automobile Popularization and Application (新能源汽车推广应用推荐车型目录) ${ }^{*}$ (hereinafter referred to as the New Subsidy Catalogue). Some PEV models in the Subsidy Catalogue are exempted from the purchase tax if these models are listed in the Catalogue of the Models of New Energy Vehicles Exempt from Vehicle Purchase Tax (免征车辆购置税的新能源汽车车型目录) ' (hereinafter referred to as the Purchase Tax Catalogue). The relationship of these government policies is shown in Fig. 3.

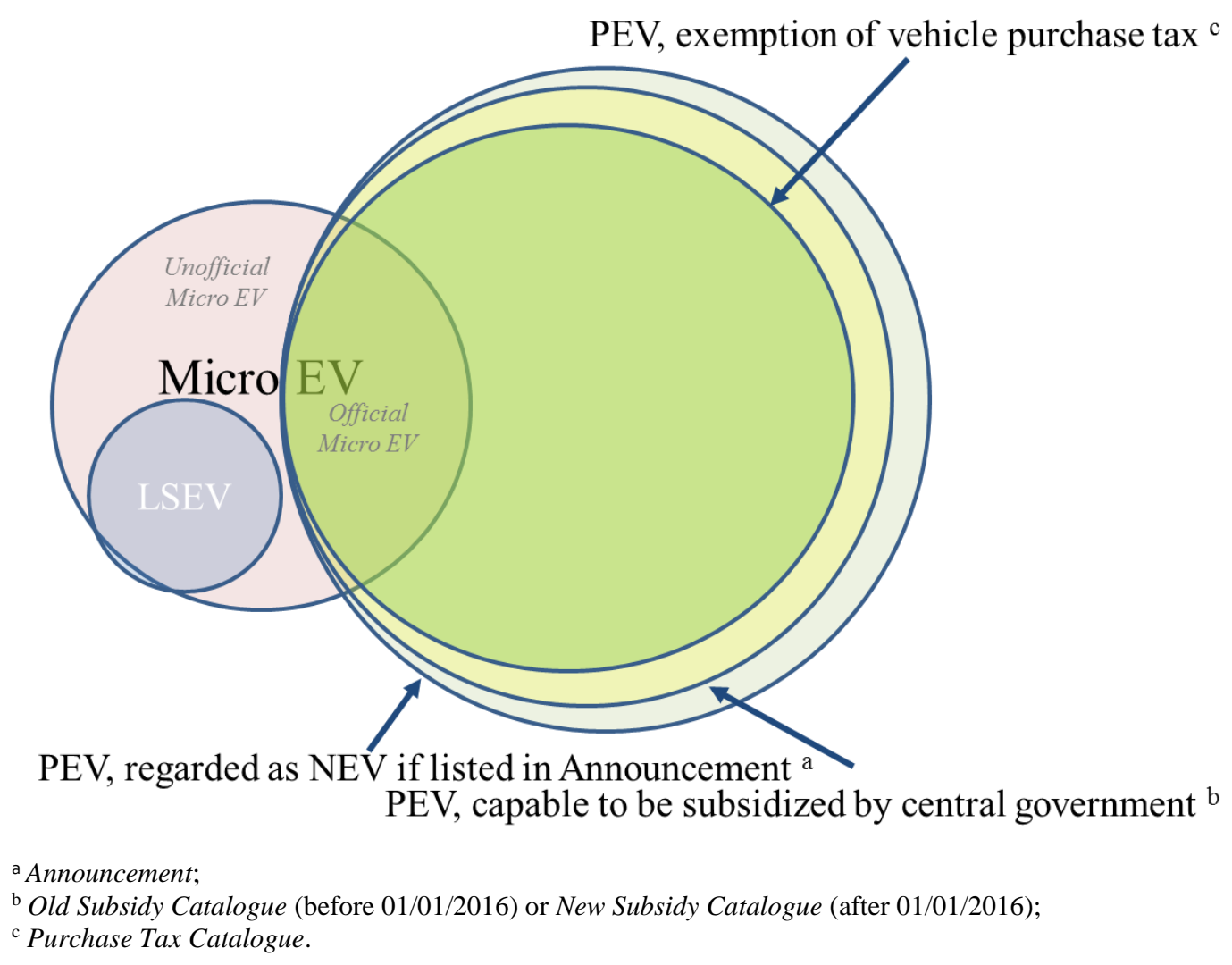

Fig. 3. Relations for LSEVs, micro EVs, and PEVs

\footnotetext{
* This New Subsidy Catalogue replaces the old version known as the Catalogue of Recommended Models for the Energy Conservation and New Energy Automobile Popularization and Application (节能与新能源汽车推荐车型目录) (Old Subsidy Catalogue) on January 1, 2016. Source by http://www.gzjt.gov.cn/gzit/web/Service/DowLoad.aspx?DowID=2678 (in Chinese)

$\dagger$ The Purchase Tax Catalogue also includes a few imported car models, such as the BMW i3 which was available since September 2015.
} 
Importantly, a large volume of low speed electric vehicles (LSEVs) or micro EVs have been sold in China in recent years. No LSEVs are in the Announcement and thus are not included in CATARC's PEV statistics. Although there are no national standards to define the LSEVs, the highest speed of the LSEVs is supposed to be no higher than $80 \mathrm{~km} / \mathrm{h}(50 \mathrm{mph})$ according to the Old Subsidy Catalogue, or higher than $100 \mathrm{~km} / \mathrm{h}(62 \mathrm{mph})$ according to the New Subsidy Catalogue. Some micro EVs are excluded by the Announcement or Subsidy Catalogue due to inconformity with the government NEV requirements, and therefore deemed as the unofficial EVs. It is worth noting that most unofficial EVs and LSEVs are micro cars and are also called unofficial micro EVs. These unofficial EVs are not included in the PEV sales data by the CATARC, but will be discussed later in this report because of their influence to the PEV industrial patterns.

\section{$2.2 \quad 2014-15$ BOOM}

The electrified vehicles (including both PEVs and hybrid electric vehicles (HEV)) have more than ten years' history in the Chinese sales market. As early as 2005, Toyota built its HEV, the Prius, in the joint venture plant in Changchun, China. The light duty PEVs were sold out in 2009 when the "Ten Cities Thousand Vehicles Demonstration Program” (十城千辆工程) was launched by the central government. However, the sales of PEVs did not start to break out until 2013 when the Chinese government dedicated more fiscal support nationally in the PEV market that targeted subsidies expansion to all buyers. Before 2013, only a few cities had incentives available for the individual buyers for private use.

BEVs dominated the light duty electrified vehicle market segment after year 2013. In 2015, more than 140,000 units of the BEVs were sold and became the most popular model in the light-duty electrified vehicle market segment, followed by the PHEVs, shown in Fig. 4. It is notable that the domestic BEVs/PHEVs which are eligible for the government subsidies, account for the majority of the China's electrified vehicle market. On the other hand, the imported electrified vehicle models dominate the HEV market segment which no longer qualifies for government subsidies as of 2013. As opposed to the other thriving electrified vehicle technologies, the development of the FCEVs relatively lagged behind. Only ten units of FCEVs were produced for demonstration in 2015. The PEV market segment in China leans on the transition of emergent phase to the growth phase, which is characterized by potential widespread adoption of the PEV technology, growth of competitor numbers, and improved established industrial standards. The current stage of the PEV market segment in China is regarded as a nascent growth phase in this report. 


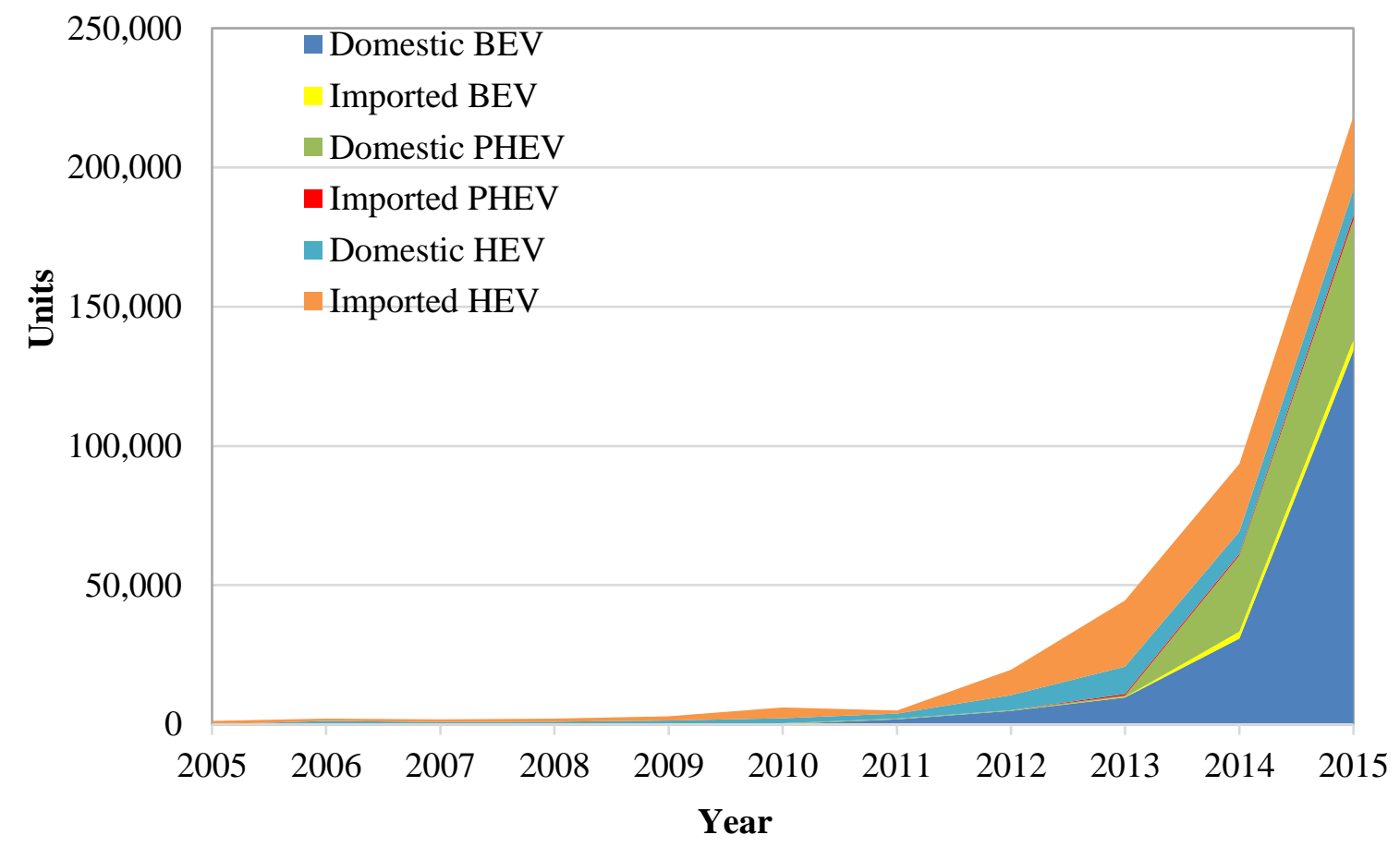

Fig. 4. New electrified light duty vehicles (BEVs, PHEVs, \& HEVs) sales in China, 2005 - 2015

In the light-duty PEV market, because of the explosive growth after 2013, China became the world's largest market in 2015, followed by Western Europe. New light PEV sales in China are compared with the markets in other major countries and regions from 2011 to 2015 in Fig. 5. In China, the light PEV sales in 2015 account for $72.1 \%$ of the total sold light PEVs during 2011 to 2015. The U.S. light PEV sales in 2015 has a slight decrease compared with 2014.

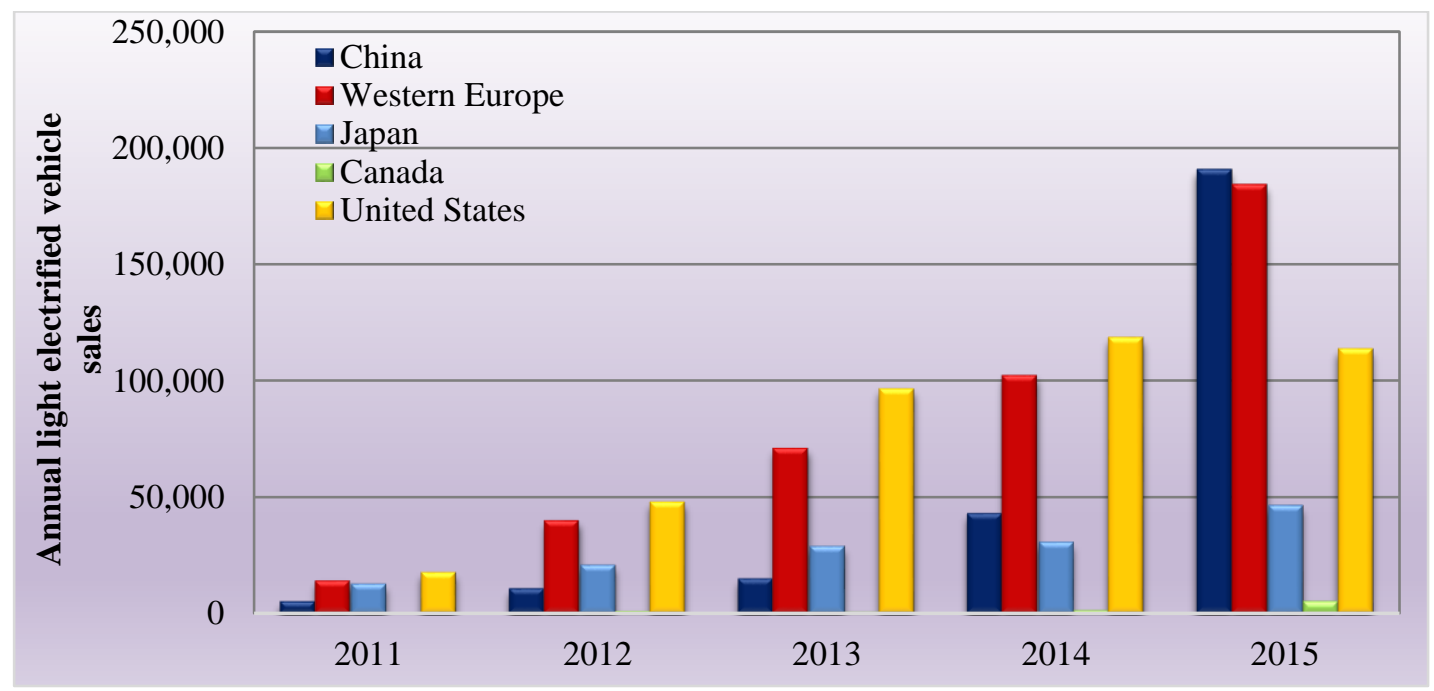

Fig. 5. Global light plug-in electric vehicle (BEVs \& PHEVs) sales, 2011-2015*

* Source by http://energy.gov/eere/vehicles/fact-918-march-28-2016-global-plug-light-vehicle-sales-increased-about-80-2015, while Chinese 2014-2015 data are corrected based on CATARC official database, U.S. 2011-2015 data are based on the Alternative Fuels Data Center of U.S. Department of Energy http://www.afdc.energy.gov/data//10567. 
Western Europe accounts for the largest light PEV fleets accumulated from 2011 to 2015, shown in Fig. 6. Though the light PEV market in the U.S. is slightly smaller, the number of units of its light PEV fleet are nearly one-third of the world.

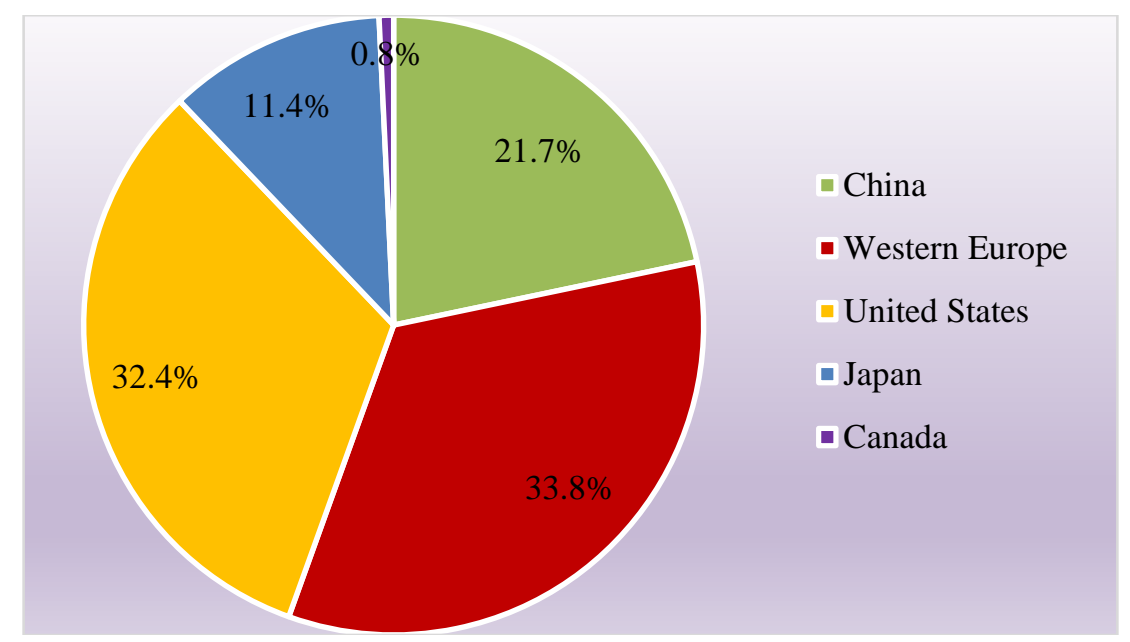

Fig. 6. Global light PEV accumulated sales, 2011-2015*

With the prosperity of the PEV market and attractiveness of government incentives, a number of PEV models have been introduced into the market by the automakers. By the end of 2015, 3,409 PEV models had been certificated by the Ministry of Industry and Information Technology (MIIT) of P.R. China and included into the Old Subsidy Catalogue before it was repealed. Meanwhile, with stricter criteria, the New Subsidy Catalogue was decreed in January 2016. The new catalogue requests all automakers to re-submit applications for their PEV models even if these models had satisfied the requirements in the Old Subsidy Catalogue. The PEV models whose names are not in the New Subsidy Catalogue will not be eligible to obtain the government fiscal support, which contributes to an inferior market position of these vehicle models in the price competition. By February 2016, 713 PEV models have been listed into the New Subsidy Catalogue. Of those listed, 596 models (84 \%) are buses and 117 models (16\%) are passenger cars.

Fig. 7 shows the distribution of vehicle-type categories for BEV sales in 2014 and 2015, respectively. In 2015, more than 133,000 units of light-duty BEVs were sold in 2015. The vehicle types of light BEVs have expanded from sedan cars to include Sports Utility Vehicles (SUVs), and Multi-Purpose Vehicles (MPVs). With the increasing demands of the Chinese middle class, and abolishment of one-child policy in China, the passenger vehicles with larger interior volumes are expected to become more attractive in the Chinese vehicle market ${ }^{\dagger}$. In 2015, $39.5 \%$ of new passenger cars sales were SUV or MPV. Therefore, the automakers started producing plug-in electric SUV or MPV models, most of which are PHEVs and a few are BEVs.

\footnotetext{
${ }^{*}$ Source by http://energy.gov/eere/vehicles/fact-918-march-28-2016-global-plug-light-vehicle-sales-increased-about-80-2015, while Chinese 2014-2015 data are corrected based on CATARC official database, U.S. 2011-2015 data are based on the Alternative Fuels Data Center of U.S. Department of Energy http://www.afdc.energy.gov/data//10567.

$\dagger$ Kongho Chua. Bloomberg News 2016. "China Auto Sales Growth Accelerates on Rising SUV Demand" http://www.bloomberg.com/news/articles/2016-07-08/china-auto-sales-grow-at-faster-pace-on-suv-electric-car-demand.
} 
The sales of the heavy-duty BEV (including buses, trucks, and special vehicles) sales are also impressive with nearly 127,000 units sold in 2015. During the second stage of the national PEV incentives in 20092013, more than $80 \%$ of PEVs sold were public fleet vehicles (mostly buses) motivated by the "Ten cities - Thousands Vehicles" Program (4). Given the fact that China has a dense population and high utilization rate of public transportation, the government PEV incentives is favorable to the deployment of public buses and sanitation vehicles*. Although cars dominated the BEV market in 2015, and the market share of the heavy-duty BEVs expanded from $19.8 \%$ in 2014 to $48.7 \%$ in 2015., Sales of electric buses in 2015 increased 15 times over 2014, which motivated the increased demands for EV batteries at the same time.

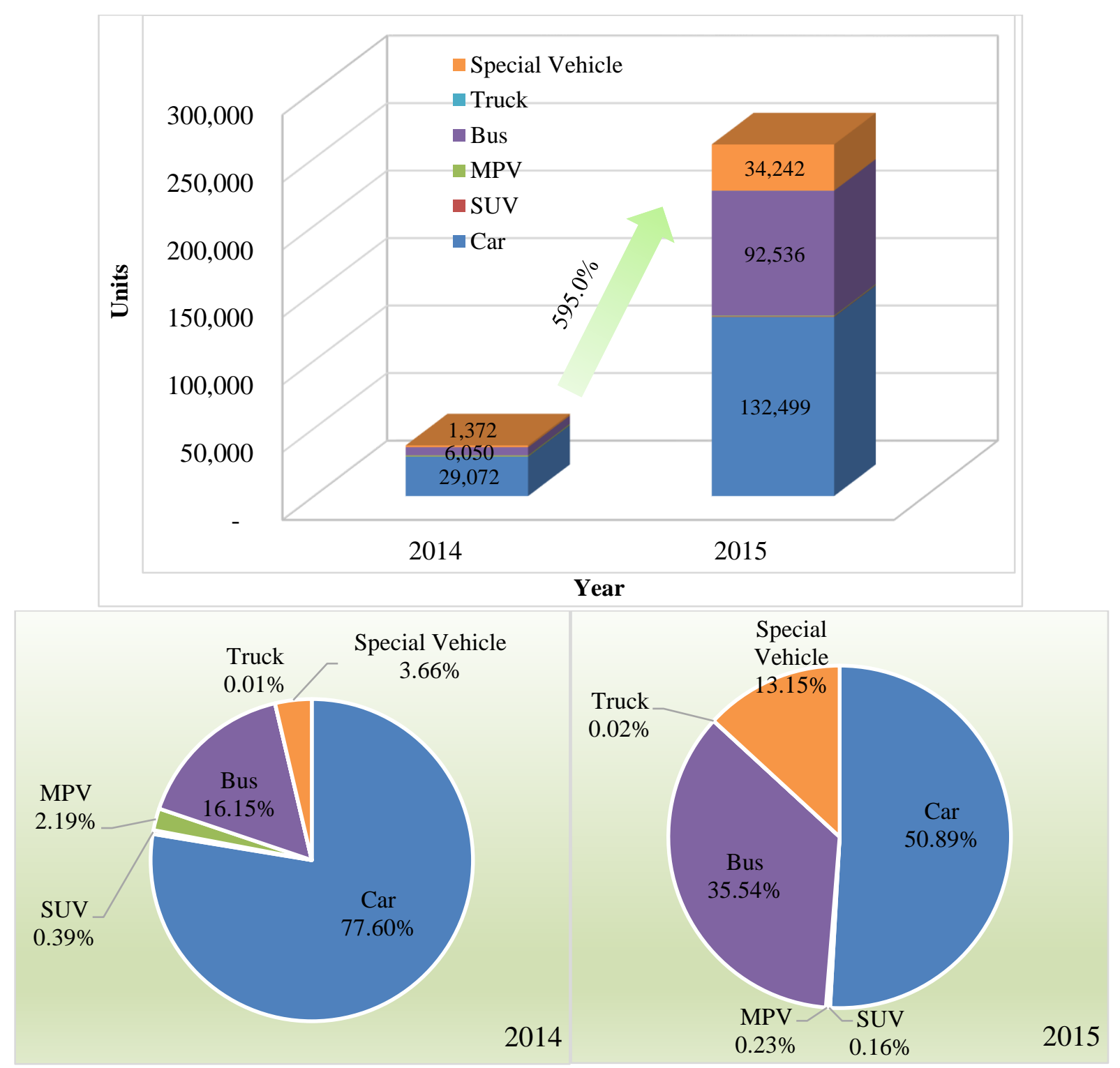

Fig. 7. Distribution of vehicle types in the Chinese BEV sales market for 2014 and 2015

\footnotetext{
* Jie Ma. Bloomberg, 2016. "China Electric Car Boom Driven by State Buying, Bernstein Says", http://www.bloomberg.com/news/articles/2016-03-01/china-electric-car-boom-driven-by-state-buying-bernstein-says.
} 
Multiple PHEV categories in 2014 and 2015 are compared in Fig. 8. In 2015, the light-duty PHEV sales are about 57,000 units, which include cars and SUVs. The heavy-duty PHEV market share dropped from $45.8 \%$ in 2014 to $30.9 \%$ in 2015. In the light-duty PHEV, SUVs were first sold in China in 2015 and represent $17.2 \%$ of the PHEV market. Although the sales of plug-in hybrid electric buses doubled in 2015 compared with 2014, the passenger vehicles are still the dominant segment in the PHEV market.

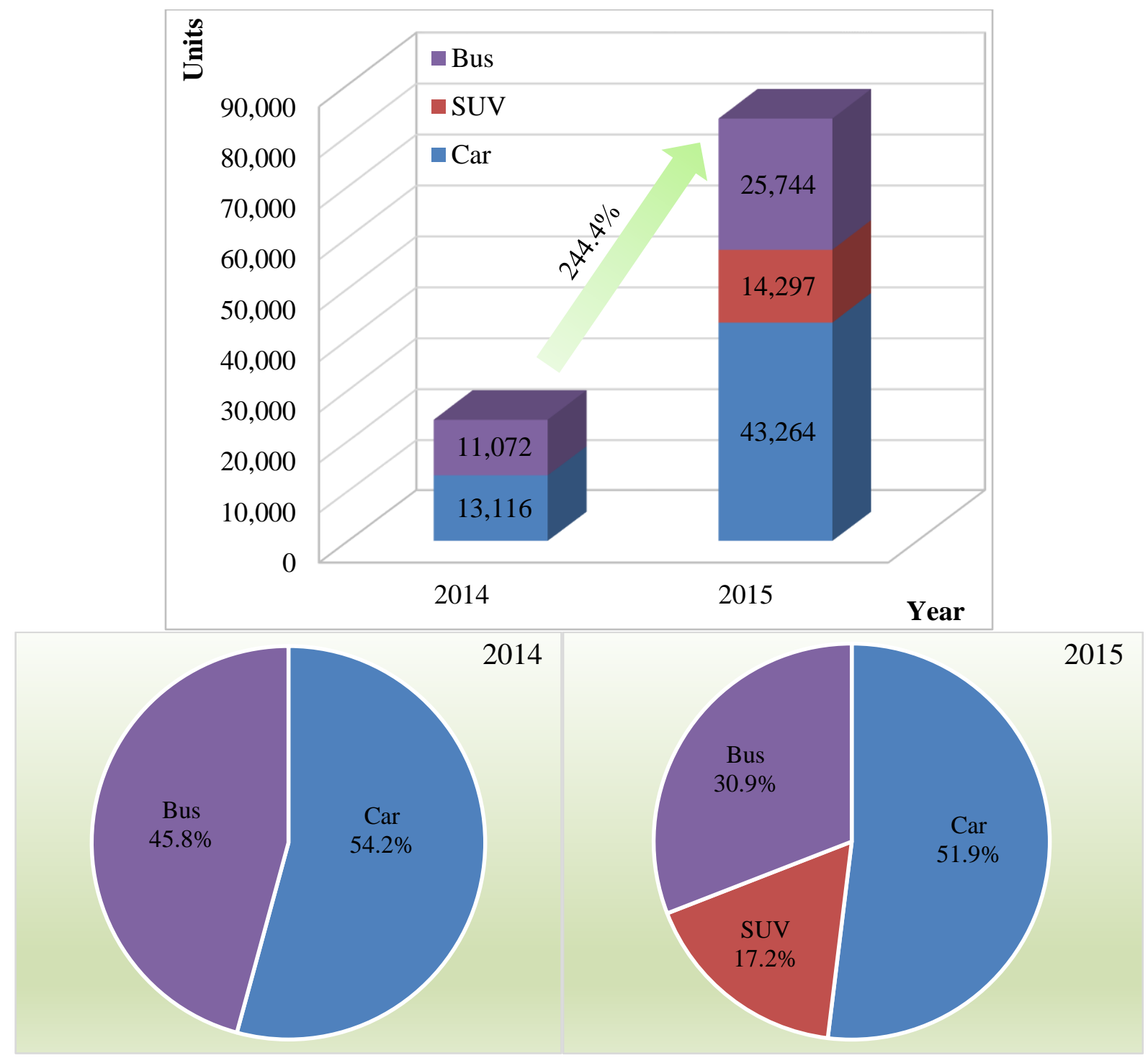

Fig. 8. Chinese PHEV sales market by vehicle category for 2014 and 2015

\subsection{FEATURES OF PLUG-IN ELECTRIC VEHICLE SALES}

The sales characteristics of the PEV market and the conventional vehicle market in China are compared in this section. Fig. 9 gives the PEV monthly sales for January 2013 to December 2015. The PEV sales in 2015 have an obvious growth in 2015 compared to the sales in 2013 and 2014. Particularly, the sales growth in the fourth quarter (Q4) of 2015 are impressive. 


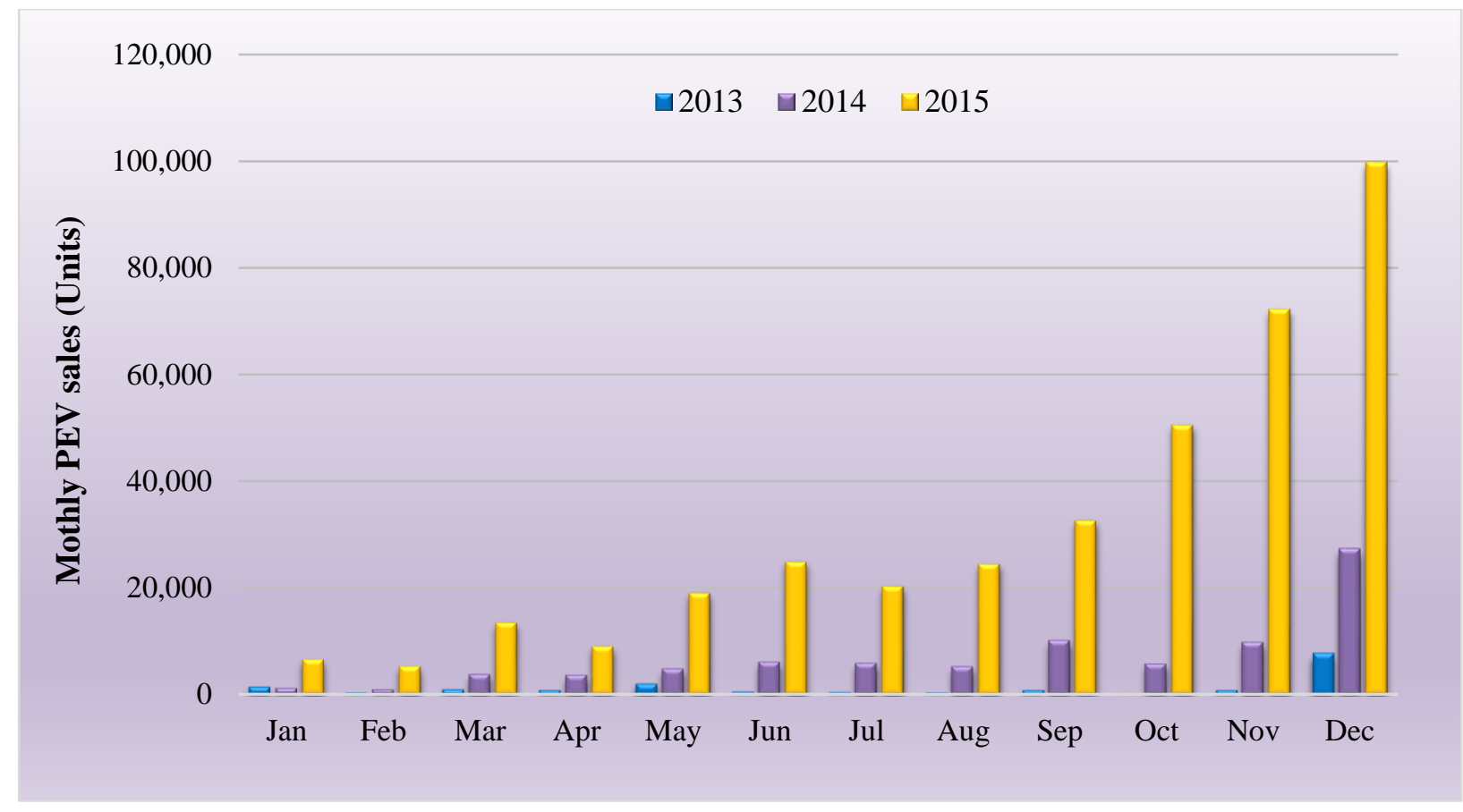

Fig. 9. New Plug-in Electric Vehicle Monthly Sales in China, 2013 - 2015 (2)

Fig. 10 presents all new vehicle monthly sales in China since 2011 to 2015 . It is normal that the vehicle sales in the Q4 is always larger than the sales in the other three quarters yearly.

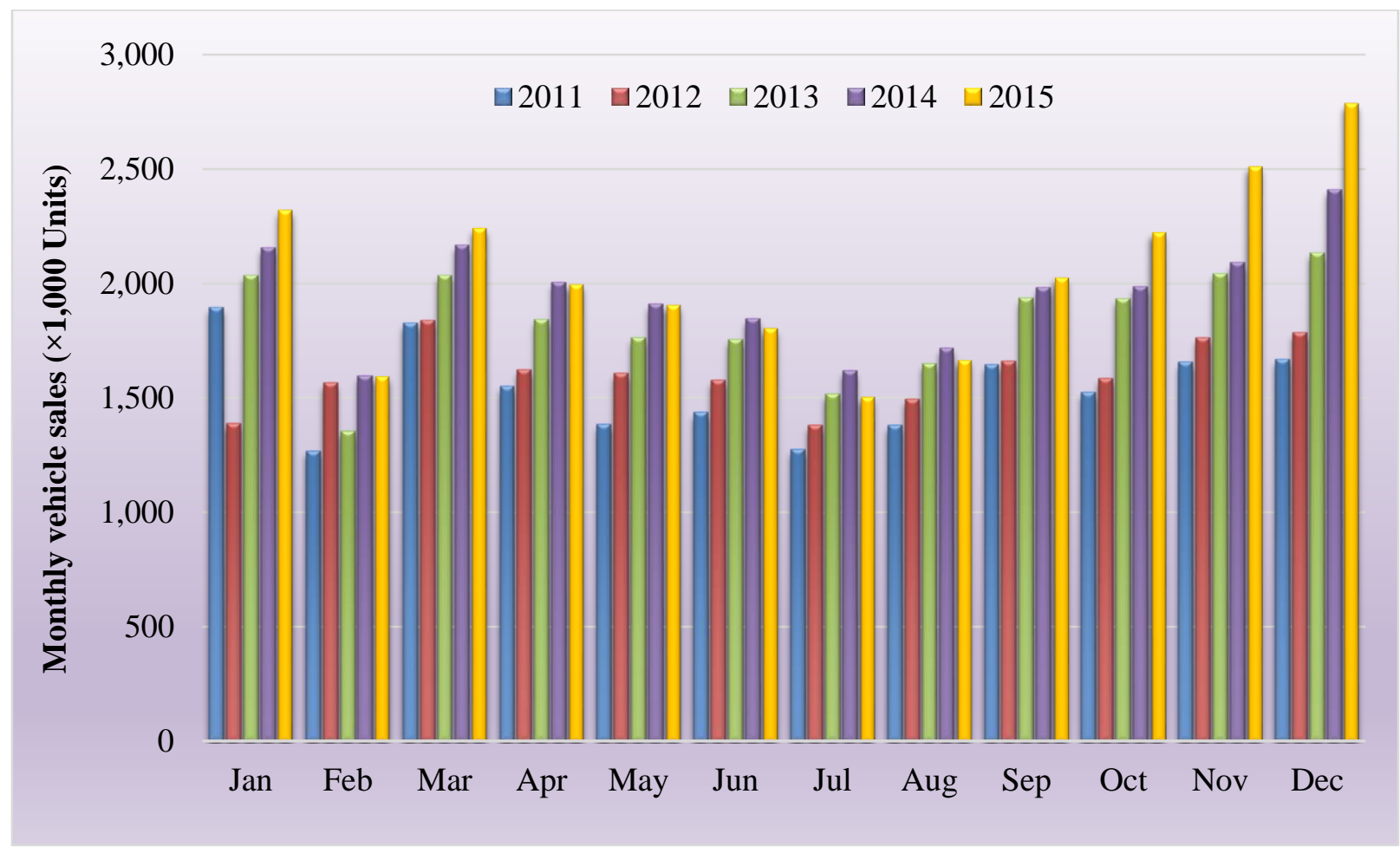

Fig. 10. Total vehicle monthly sales in China, 2011 - 2015 (2) 
In general, the pattern of PEV monthly sales appears to be consistent with that of the conventional vehicles, but the year-end sales surge is more stark for PEVs in 2015. Fig. 9 gives the PEV monthly sales in the most recent 3 years and Fig. 10 gives all vehicle monthly sales in China for the most recent 5 years. In the month of February, often a holiday month in China, is the sales downturn month for the market segments of both conventional vehicles and PEVs in China. The only exception is in the year 2012 when the lowest monthly sales volume was in January, which is because the Chinese New Year date (January 23) was much earlier than it is in other years. The summer months (June to August) is the season with the worse vehicle sales volumes, and is more evident in the conventional vehicle market; fortunately, the sales volumes revive in the Q3. The average monthly sales for both PEVs and all vehicles in the Q4 are larger than the average monthly sales in the other three quarters of the same year. This is because starting from the Q3 in every year, the dealerships in China carry out various discount promotions to stimulate their vehicle sales, which is regarded as the Golden September \& Silver October ${ }^{*}$, and the automotive manufacturers have pressure to fulfil the fiscal year sales plan before the end of a year (5). In addition, the vigorous market demands also impact the sales growth in the Q4 when the Chinese consumers need vehicles to prepare for coming holidays.

At the same time, the prosperous vehicle market is inseparable from the vehicle incentives, though the vehicle sales are affected by consumer behaviors, provider's market strategies, and economics development etc. In the conventional vehicle market, the incentive where the purchase tax was cut in half for the <1.6 L (vehicle engine displacement) cars was enacted in August 2015, which may have influenced all new vehicles sales growth in 2015 Q4 since the data show that more <1.6 L cars were sold. In the PEV market, the PEV sales especially, the commercial vehicles are greatly influenced by the government procurement, and the orders from governments are usually in the second half of a year, which is an important factor to the growth of the PEV sales in the Q3 and Q4. The uncertainty of 2016 PEV incentives and subsidies might drive the unusual explosive increase of PEV production and sales in 2015. Fear that the government subsidies would be withdrawn from the PEV market and stricter PEV standards would be carried out by government in 2016, some automakers tried to sell as many PEVs as possible to obtain the subsidies should they be no longer subsidized in 2016. Considering that the government subsidy policies and regulations become more elaborate and industrial standards are stricter in following years, the growth rate of the PEV sales would be relatively stable and gentle if the PEV market is majorly policy-driven instead of market-driven.

\subsection{MARKET COMPETITION AND INDUSTRY ORGANIZATION}

The compact cars (Class A) or smaller classes are one of the most popular PEVs in China (2). Table 2 gives the ten best-selling PEVs in China in 2015. It shows that all of these best-selling vehicle models belong to Class A or smaller. As can be seen in Fig. 11, the total share of these ten best-selling PEVs reached $78.13 \%$ in the light-duty PEV market, and reached $43.46 \%$ in all PEV market.

\footnotetext{
* Helen Hao. Gasgoo 2015. "Chinese auto market recovery immersed in impediments despite favorable season approaching." http://autonews.gasgoo.com/china-news/chinese-auto-market-recovery-immersed-in-impedimen-150831.shtml (visited in April, 2016)
} 
Table 2. Ten best-selling PEV models in Chinese market, 2015 (2)

\begin{tabular}{|c|c|c|c|c|c|}
\hline Rank & Model & OEM & Powertrain & Class & $\begin{array}{c}\text { Electric } \\
\text { Range }(\mathbf{k m})\end{array}$ \\
\hline 1 & Qin & BYD & PHEV & A & 70 \\
\hline 2 & Zhidou & Geely & $\mathrm{BEV}$ & $\mathrm{A} 00$ & 180 \\
\hline 3 & EV 200 & Beijing Auto (BAIC) & BEV & $\mathrm{A} 0$ & 245 \\
\hline 4 & Yun-100 & Zotye & $\mathrm{BEV}$ & $\mathrm{A} 00$ & 150 \\
\hline 5 & Tang & BYD & PHEV & A & 60 \\
\hline 6 & $\mathrm{~K} 10^{a}$ & Kandi & $\mathrm{BEV}$ & A00 & 150 \\
\hline 7 & Roewe E550 & Shanghai Auto (SAIC) & PHEV & A & 60 \\
\hline 8 & Panda K1 ${ }^{a}$ & Kandi & $\mathrm{BEV}$ & A00 & 150 \\
\hline 9 & $\mathrm{iEV}$ & JAC & $\mathrm{BEV}$ & $\mathrm{A} 0$ & 160 \\
\hline 10 & Zhidou 301 & Zotye & $\mathrm{BEV}$ & $\mathrm{A} 00$ & 85 \\
\hline
\end{tabular}

${ }^{a}$ In 2015, Kandi Auto did not have the qualification certificate for PEV production, thus Kandi K10 and Kandi Panda K11 are made by Geely who collaborates with Kandi Auto in PEV market.
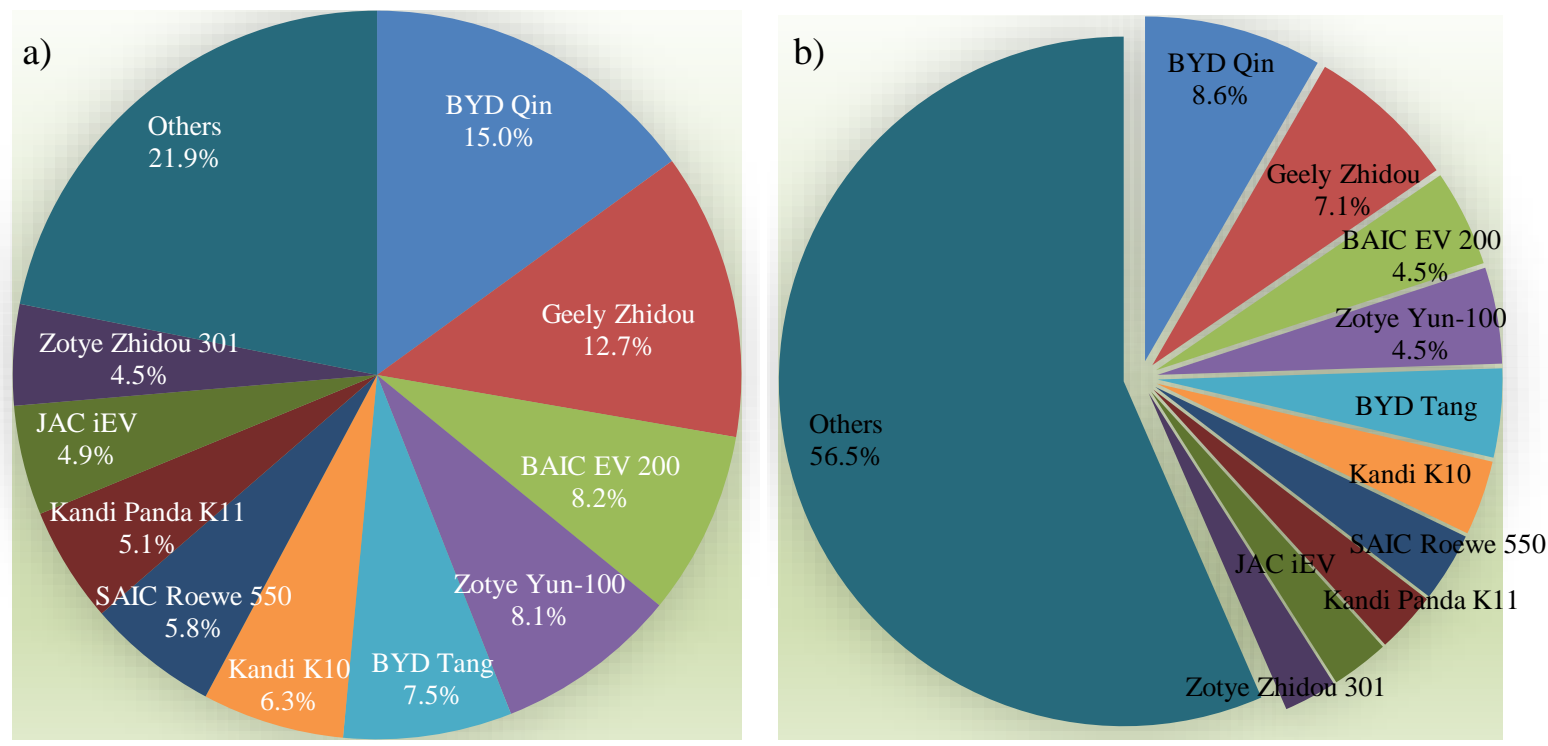

Fig. 11. a) New light PEV market share by models, 2015; b) new PEV market share by models, 2015

The MSRPs (manufacturer's suggested retail prices) of the best-selling PEVs are higher than the average MSRP of conventional cars in the same class. Fig. 12 shows the sales and MSRP (basic car model) for the 10 best-selling PEV models. Based on the data from the China Association of Automobile Manufacturers, the average MSPR for an A0/A00 (Subcompact/Micro) car is $¥ 44,000 \sim ~ ¥ 46,300 \mathrm{CNY}$ (\$6,781 $\$ 7,135$ USD)*. The average MSRP of the Class A0/A00 PEVs is 164,114 CNY (\$25,291 USD) which is still much higher than the average price of a conventional car. Fig. 13 presents the price distribution of the

\footnotetext{
* China Association of Automobile Manufacturers. 2016. "The prices of China brand cars are 45\% lower than the foreign brand cars in the same class (同级别车均价较合资低 $45 \%$ 自主成本困局待解)”.

http://www.caam.org.cn/hangye/20160608/1005193405.html (in Chinese) (visited in April, 2016)
} 
PEVs sold to private consumers, which shows that the PEVs with MSRPs (before subsidies) less than $¥ 250,000 \mathrm{CNY}$ (\$38,500 USD) are more appealing to the private consumers in China. With the subsidies from government, the actual price to the PEV buyers is much lower than the MSPR, nevertheless the actual price to consumers can be $40 \%$ of the original MSRPs.

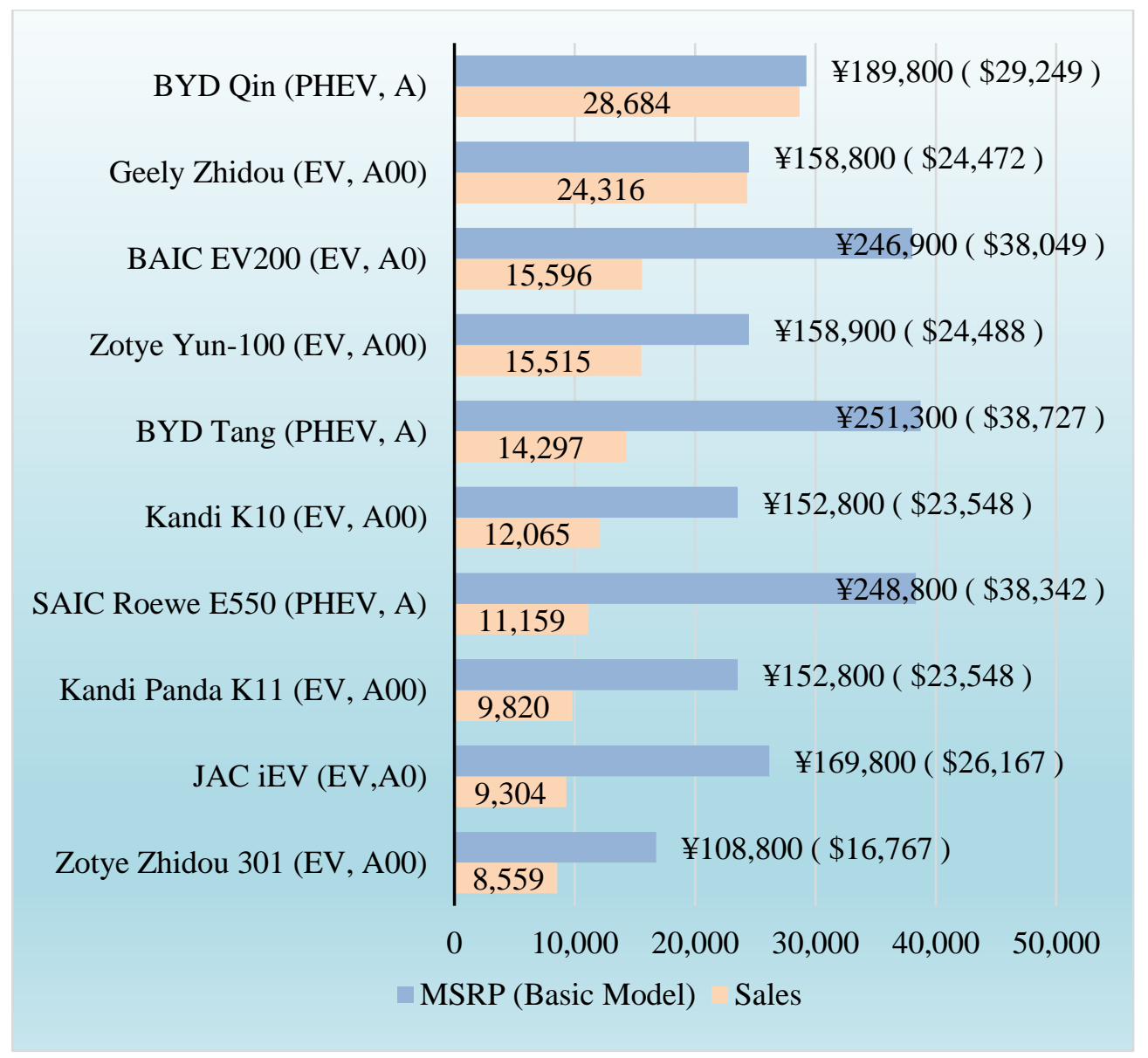

Fig. 12. Sales Volumes and prices for 10 best-selling PEVs (basic model) in China, 2015 ${ }^{* \dagger}$

\footnotetext{
* Source by D1EV Website, “Electric Vehicles Information Database (车型大全)”, http://www.d1ev.com/salecar (in Chinese) (visited in April, 2016)

†Shi Chen. A0EV, 2016. “The Best-selling Electric Vehicles in Year 2015 (2015 年电动汽车销量前 10 排行出炉)”, http://www.aooev.com/html/201601/59439.html (in Chinese) (visited in April, 2016)
} 


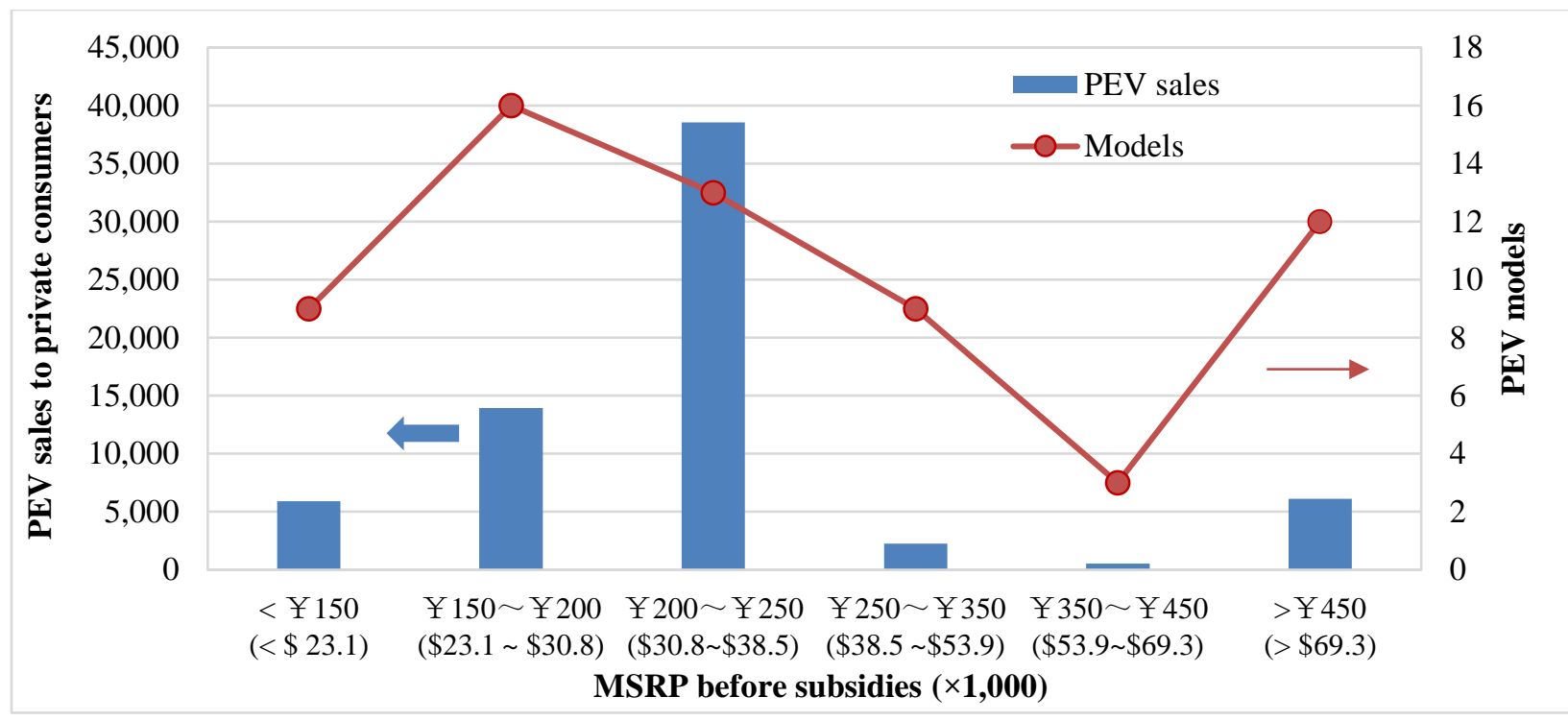

Fig. 13. Price range distribution of private purchase PEVs in China, 2015 (2)

China's PEV market is in a highly competitive, low concentrated, and early growth stage. The policy of "market access in exchange for technologies" in the Chinese automotive industry has been deemed as an unsuccessful tactic in technologically transferring (4).China's policy makers regard for the electrified mobility revolution as a great opportunity to leapfrog foreign competitors, and motivating the technology upgrade of numerous domestic enterprises in the economic transition period, which then propels the investments flow into the PEV industry. Some characteristics of the PEV market are manifested by Fig. 14 and Fig. 15.

First, the PEV market is fragmented. Fig. 14 presents the market shares by automakers for both conventional vehicles and PEVs. Commonly, the multinational automakers or capitals operate joint ventures with a specific Chinese domestic enterprise (mainly state-owned auto manufacturer) to produce vehicles (6), thus the names of the multinational auto firms who have plants in China are not shown in Fig. 15 a). In the conventional vehicle market, the five largest automakers by sales already have $72.6 \%$ of the market share. However, the PEV market concentration is relatively smaller - the five largest PEV automakers based on sales only take $45.6 \%$ share of the market. Based on the statistics from the Ministry of Finance, 169 units of domestic manufacturers have PEV products*, however only two OEMs, BYD and Geely, have shares over $10 \%$ in the PEV market, respectively, shown in Fig. 14 b). At the same time, numerous PEV models have been brought into the market by these hundreds of PEV automakers. More than 3,409 PEV models were certified and listed into the Old Subsidy Catalogue before it was repealed at the end of 2015. On the other hand, only 14 OEMs sold over 1,000 units of PEVs in 2015, shown in Fig. 15. Three out of 169 PEV OEMs have more than $5 \%$ market share, respectively. Therefore, it is not surprising that some OEMs only sold dozens of PEVs or have no PEV models sold at all. The fragmentation of the PEV industry results and difficulties in mass production for PEVs heavily increases the PEV manufacturing marginal cost and lack of OEM's competitiveness.

\footnotetext{
* Yue Zhang. Ministry of Finance of PRC 2016. "Why the government should not keep subsidizing the New Energy Vehicles (财 政为何不能长久补贴新能源汽车? )", http://www.mof.gov.cn/zhengwuxinxi/caizhengxinwen/201603/t20160302_1828176.html (in Chinese) (visited in Sept, 2016)
} 
Second, many entrants in the PEV market rarely have experience in vehicle manufacturing. Generally, the entrants are typically grouped into certain types: The entrepreneurs with abundant venture capital (VC); and the manufacturers who used to be in the upstream product chain in automotive industries or neighbor industries such as low-speed or neighborhood vehicles who were pressing to upgrade their products. With the plentiful VCs, many entrepreneurs are participating in the car manufacturing PEV industry. These entrepreneurs often have had rich management experience and networking in the conventional vehicle industry, and left their original positions to bet on the PEV market as the right horse in their startup business. For example, NextEV (蔚来汽车), established in 2015, is a startup firm which has obtained $\$ 500$ million USD from VCs, and promises to build a Chinese electric super car with innovative features in 2018, just like what Tesla did". In principle, the Chinese government will not approve any new conventional vehicle manufacturers to be built in $\mathrm{China}^{\dagger}$. For the entrants who transformed from the upstream chain or low end manufacturing industries, the only window in the automotive industry opened for them is PEV projects. For many of the entrants, because of the lack of efficient strategies (such as viable technologies, assembly experience and quality control), their business strategy is to sale low-cost, low-performance as many as possible PEVs to cannibalize the market share and obtain the government subsidies.

Additionally, the facts that the technological barriers and high sunk costs stymie the entrants into the conventional vehicle market which is an industry with monopoly rents dominated by a few state-owned OEMs with their foreign partners in China. The conventional vehicle industry has a high minimum efficiency scale, where the strict industrial standards, large scale distribution, and various technological requirements entail professional labor training with completed R\&D system and sustainable investments. The incumbents who have had large economies of scale and integrated distribution channels also deter the other investors in the conventional vehicles. It is a bet worth making for private enterprises or VCs to penetrate the PEV supply chain which is an emerging market segment in China, especially with the support from the government promising incentives and policies. For example, in order to seize the opportunity to enter the market, Kandi Auto, a private-owned automaker, has started producing PEVs by collaborating with another certificated automaker (Geely) before it got the government certificates for its PEV products. (Kandi's products and sales are counted into Geely's in 2015). Two popular BEV car models, Kandi K10 and Kandi Panda K11, gave Kandi Auto $11.4 \%$ share in the light-duty PEV market in 2015.

Third, the traditional domestic state-owned automakers who dominate the conventional vehicle market are less proactive in the PEV market. Shown in Fig. 14, the names of these incumbents in the conventional vehicle market segment are replaced by the names of the domestic private-owned enterprises or small state-owned automakers. In Fig. 15, 7 out of 20 largest OEMs by PEV sales are domestic private-owned automakers, many of which have foreign shareholders

\footnotetext{
*Huang Peng. Tencent Auto Voice. 2015 . “How is NextEV heading to the future? (蔚来汽车如何驶向未来?)” http://auto.qq.com/original/cheshidian/autovoice081.html (in Chinese)

† The State Council Information Office. 2016. “China unveils measures to promote private investment (政府核准投资项目“再瘦 身”释放市场活力)” http://www.scio.gov.cn/32344/32345/33969/35257/35264/Document/1493927/1493927.htm (in Chinese) $\$$ This study defines the companies controlled over $51 \%$ stocks with the management directly by domestic private as domestic private-owned companies, or by state as state-owned companies; This study defines the companies with foreign capital investment and with foreign management board members as foreign joint-ventures.
} 
The incumbent auto makers are more precautious and have less willingness to distract the profitable business from their joint ventures in conventional vehicles which are in high demand. In fact, most stateowned auto firms have had strategic plans or R\&D investments in the PEVs; however, they are reluctant to cannibalize their existing products i.e., conventional vehicles after trading off between short-term and long-term competencies. For example, the FAW Automotive, one of China's largest state-owned OEMs by sales in conventional vehicle market, has poor performance in their PEV marketing although it has advantages marketing and manufacturing. Though FAW published its roll-out plan in the PEV industry in 2014 and showed ambition in this new battlefield, only one PEV was produced during the first seven months in 2015 according to the report by D1 EV*. Per the report, FAW has lagged behind other competitors at the starting line in PEV market competition. Meanwhile, another incumbent state-owned enterprise, BAIC (Beijing Auto), has taken the leading position in the PEV market with 16,648 units of PEV sales in 2015.

To obtain, maintain and defend the competitive position in the dynamic PEV market, the firms need to innovatively response to the changes (new technology, new business model, or customer demands).

Considering it is still a nascent growth ramp-up phase for the PEV market in China, the incumbent stateowned OEMs still have the competitive edge in the long term by relying on the advantages in the government financing, extensive capitals and expertise, assurance of after-sales service, and technological support from their multinational strategic alliances for their sustainable innovations. The new players, especially the private-owned PEV OEMs with low innovation investment and low-end products, would face the challenges from policies, changes of consumer preferences, and fierce market competition at the later growth phase of the PEV market. Some pioneering competitors will whiter away, and the PEV market segment will enter a mature phase when only a few large and efficient firms remain. According to the published market planning by the domestic OEMs, Fig. 16 summarizes the domestic PEV passenger vehicle models which are planning to be launched into market in 2016 to 2020. It shows that most PEV models are concentrated into the BEV models with Class A or smaller size.

a)

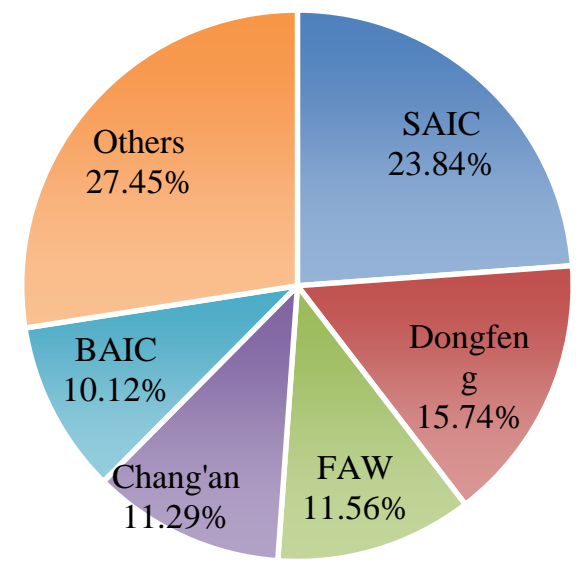

b)

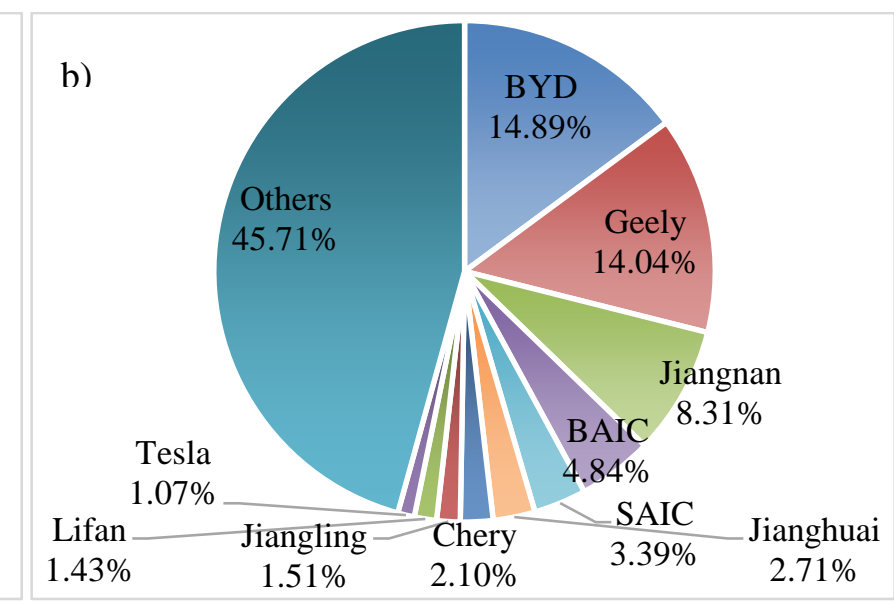

Fig. 14. a) China new vehicle market share by manufacturer, $2015^{\dagger}$; b) China new PEV market share by manufacturer, 2015 (2)

\footnotetext{
*Yanjiao Li, D1EV(第一电动网) 2015. “Ranking list of Laggards in China's NEV industry: FAW is the Tailender (中国新能源 汽车差生排行榜: 一汽最差劲)”. http://www.d1ev.com/39841.html (in Chinese) (visited in April, 2016)

$\dagger$ Source by http://www.miit.gov.cn/n1146312/n1146904/n1648362/n1648363/c4622444/content.html (in Chinese)
} 


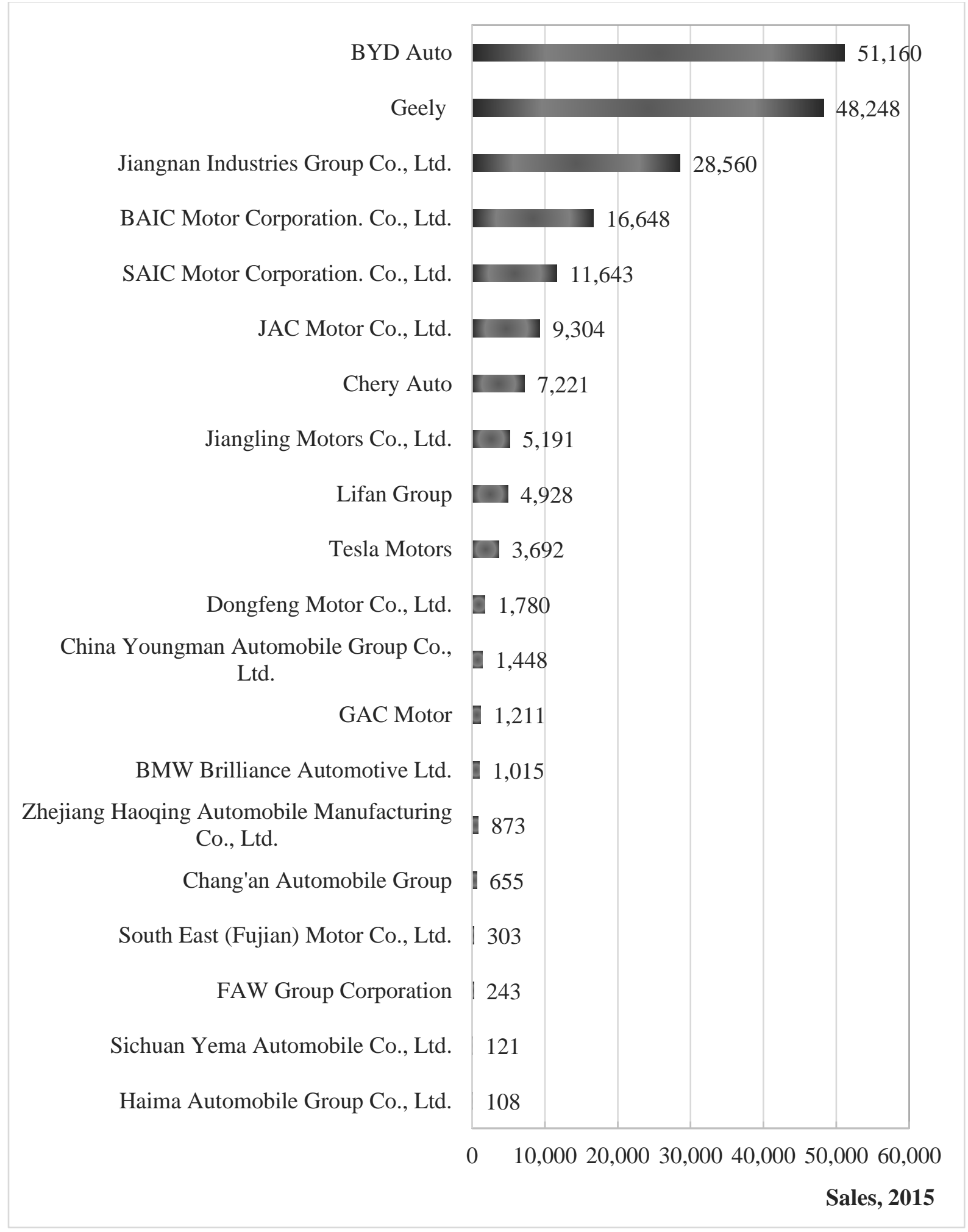

Fig. 15. Twenty largest PEV manufacturers by sales in China's market, 2015 (2) 


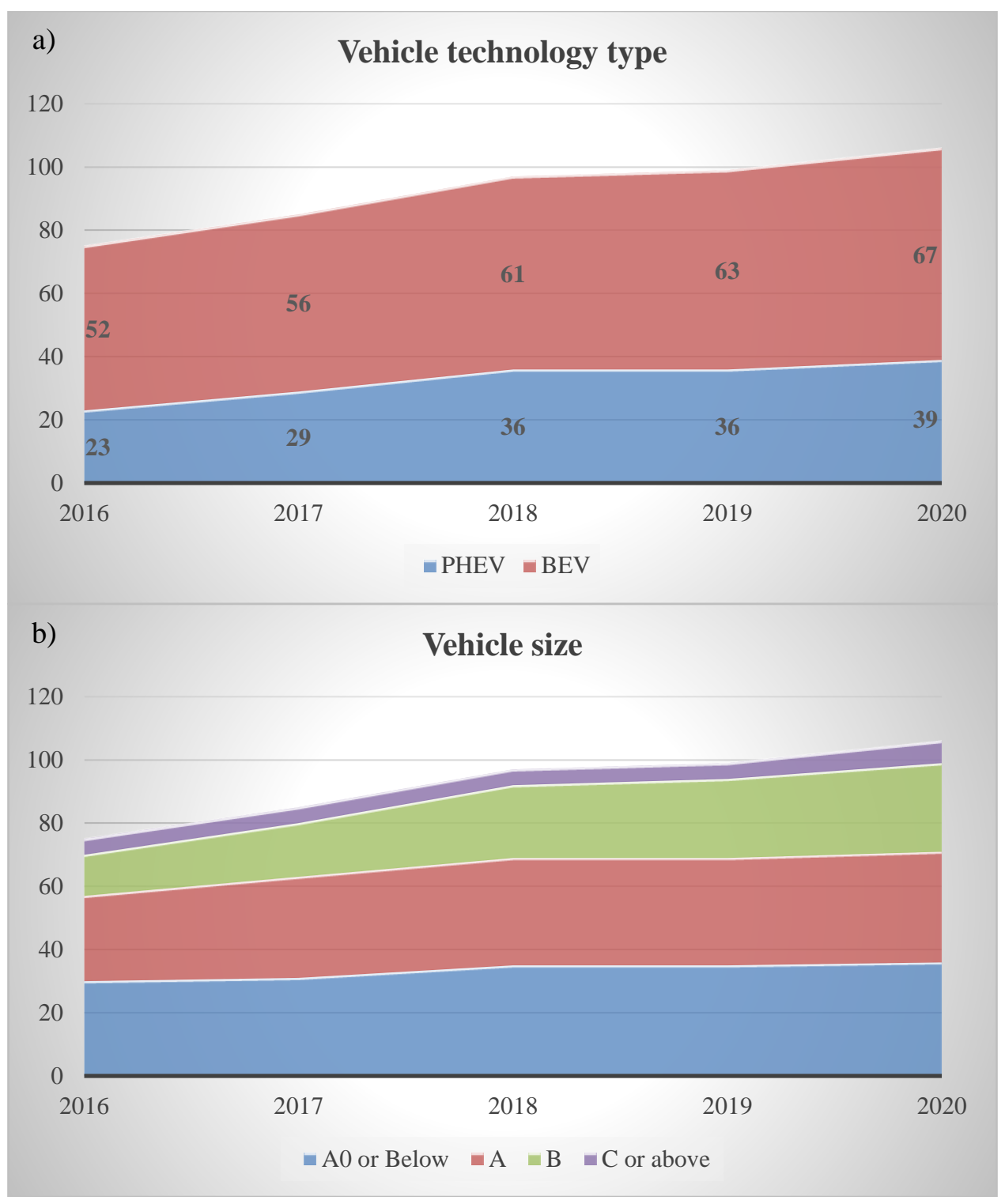

Fig. 16. a) Model units of the domestic passenger PEVs by technology type in 2016-2020; b) model units of the domestic passenger PEVs by vehicle size in 2016-2020 (2)

The PEV market offers a great platform for the small private-owned automakers in technological transition and gaining the first-mover advantage in market (significant occupant of the PEV market sales). In 2015, all three of the largest PEV enterprises who account for $37.24 \%$ of PEV sales are domestic private-owned, and their total sales volumes exceed the sum of the sales by the other remaining 17 automakers. Shown in Table 2, the domestic private-owned OEMs have seven car models (BYD Qin, Geely Zhidou, Kandi Panda EV, BYD Tang, Zotye Yun-100, Kandi K10 and Zhidou 301) in the 10 bestselling PEVs. Kandi Auto and Zotye Auto, who both own the best-selling PEV models in 2015, provide two good examples for the domestic private-owned manufacturers who expect to upgrade technologies and production chains by entering the PEV market. These two domestic manufacturing firms primitively accumulated capital in neighborhood vehicles and low speed vehicles, and related components; neither of them had rich experience in the conventional automotive manufacturing before they strategically started investing into PEVs in 2008. To break even quickly and expand the shares in the market, Micro (A00) 
and Subcompact (A0) low-end cars with simplified and low-performance configurations are the primary products for these emerging private-owned PEV manufacturers.

BYD, as a domestic private-owned automaker, has become the largest automaker with more than $16 \%$ shares in Chinese PEV market in 2015. Except for contributing two PHEV models (BYD Qin, BYD Tang) in the best-selling PEVs ranking in 2015, BYD Auto has had various PEV products including plugin electric buses and passenger plug-in electric cars from Class A0, A, B to C. Unlike many inexperienced private-owned PEV makers, BYD owned a series of conventional automotive product lines and has accumulated experience in both automotive marketing and R\&D since 2003. By integrating its technology advantages in batteries and conventional vehicles (BYD has operated its business in both battery and conventional vehicle manufacturing for years), BYD's PEV products have won a good reputation. After years of focusing on its homeland, BYD has been expanding its PEV business in the overseas market slowly but steadily with its electric buses. In 2015, BYD won U.S.'s largest electric bus order-800 heavyduty electric buses for Washington State Department of Transportation*. In the same year, by collaborating with the British bus maker Alexander Dennis Limited (ADL), BYD supplied London with 51 electric buses which is the first large-scale electric bus fleet in Europe ${ }^{\dagger}$. In 2015, the units of PEVs sales by BYD reached 55,084, which makes the BYD one of the largest PEV manufacturers in the world (2).

The substantial growth of the numbers of the domestic private-owned automakers brought about the explosive growth of PEV sales in 2015. Moreover, the government monetary incentives catalyzed the sales growth. Comparing with the incumbent automotive manufacturers, the young inexperienced privateowned PEV makers are sensitive to the manufacturing costs, and vulnerable to the market and policies. On the one hand, the domestic manufacturers are investing to upgrade their plants for vehicle manufacturing and flooding the PEV industry chain with the essential support from both central and local governments. On the other hand, because these enterprises worried about the discontinuation of the government policy, some domestic private-owned PEV makers are myopic in their business model, aiming at the low-cost low-end vehicle market which has been a brutal battle field and balkanized by too many domestic competitors. The fierce competition and the generous monetary incentives lured some enterprises to use deceptive tactics (falsify the PEV production and sales numbers, produce unqualified PEVs etc.) for government subsidies

What's interesting to note, is that in terms of geographical distribution of the primary PEV manufacturers in China, the headquarters of many PEV OEMs are more concentrated in south China (Yangtze River Area \& Pearl River Delta). Fig. 17 shows the top 15 automakers in 2015 in four regions: Pearl river delta, Yangtze river region, Circum-Bohai Sea, and the Northeast Region. Fig. 18 shows the top 15 automakers in PEVs in 2015, which shows that these PEV OEMs are more located in south China.

\footnotetext{
* BYD Motors Inc. PRNewswire 2015. "BYD Motors Wins America's Largest Electric Bus Order”. http://www.prnewswire.com/news-releases/byd-motors-wins-americas-largest-electric-bus-order-300138125.html

$\dagger$ Xinhua 2015. "BYD to supply 51 electric buses for London". http://www.chinadailyasia.com/business/201507/29/content_15297298.html (visited in April, 2016)

\# Press office of Ministry of Finance, 2016. "Notification of the Inspection of the Subsidies for the New Energy Vehicle Population (新能源汽车推广应用补助资金专项检查的通报)”. http://www.mof.gov.cn/zhengwuxinxi/bulinggonggao/tongzhitonggao/201609/t20160908_2413434.htm (in Chinese)
} 
When choosing a location for a business, various factors should be considered such as the residents and provincial government's support, logistics, distribution channels, and local economic development, and so forth. The geographical distribution of China's PEV manufacturing plants imply that more unique factors should be taken into consideration.

- South China houses an integrated automotive production chain. The Yangtze river region and Pearl river delta are two regions in conventional vehicle manufacturing with well-developed industrial support facilities (equipment, $R \& D$, distribution etc.) and integrated upstream suppliers. In the conventional vehicle segment, both the leading incumbents (such as SAIC [上汽], Dongfeng [东风], and Chang'an [长安]), and other contenders (such as Geely [吉利汽车], GAC [广汽], and BYD [比 亚迪]) are located in south China. It is easier for these enterprises to layout their product transition to the PEVs locally.

- Generally, with better financial situations, the southern provincial governments can provide a series of stable monetary incentives to the PEV industry. In recent years, China is experiencing an economic transition where the GDP growth is sliding down, and the situation is especially more serious in the northeastern provinces which hardly fiscally support the local firms in the PEV market.

- South China houses a lot of well-developed metropolises (such as Yangtze River Delta, Pearl River Delta, and metropolitan areas along the Yangtze River) with dense population and integrated infrastructure, which supplies sustainable demand and development space for the PEVs. Undeniably, the trade barriers (regional protectionism) result in a better competitive position for the local automakers. It is the same for Beijing, where the municipality refuses to subsidize the PHEVs predominantly produced by OEMs outside of Beijing. Incidentally, BAIC, as the only state-owned auto firm located in Beijing and produces BEVs only, which has been blamed as a regional protectionism*.

- The domestic private capitals are proactive and in the early development stage of the PEV industry, and these domestic private capitals raised funding mainly in south China. Notably, all the large private-owned PEV automakers based on sales are in the south, especially in the Yangtze River Delta including Shanghai and Zhejiang province where Geely (吉利汽车), Kandi Auto (康迪汽车), Youngman Auto (青年汽车), and Haoqing Auto (豪情汽车) are all private-owned enterprises. Zhejiang, a province famous for its vital individual and private economy sector which contributed $63 \%$ of provincial GDP by the end of $2014^{\dagger}$, carve out a friendly institutional environment for the private capitals to astutely seize the opportunities in the vehicle industry revolution.

\footnotetext{
* Zhi Wu etc. Xinhuan 2016. "The Tech/non-tech Barriers and Regional Protectionism Deter the Development of PEV Market. (设置技术或非技术壁垒 地方保护迟滞新能源车推广)” http://news.xinhuanet.com/auto/2016-01/14/c 128627305.htm † G20 official website 2016. "About Zhejiang - Economic \& Development”. http://www.g20.org/English/Zhejiang/201511/t20151103_1138.html (visited in September 2016)
} 


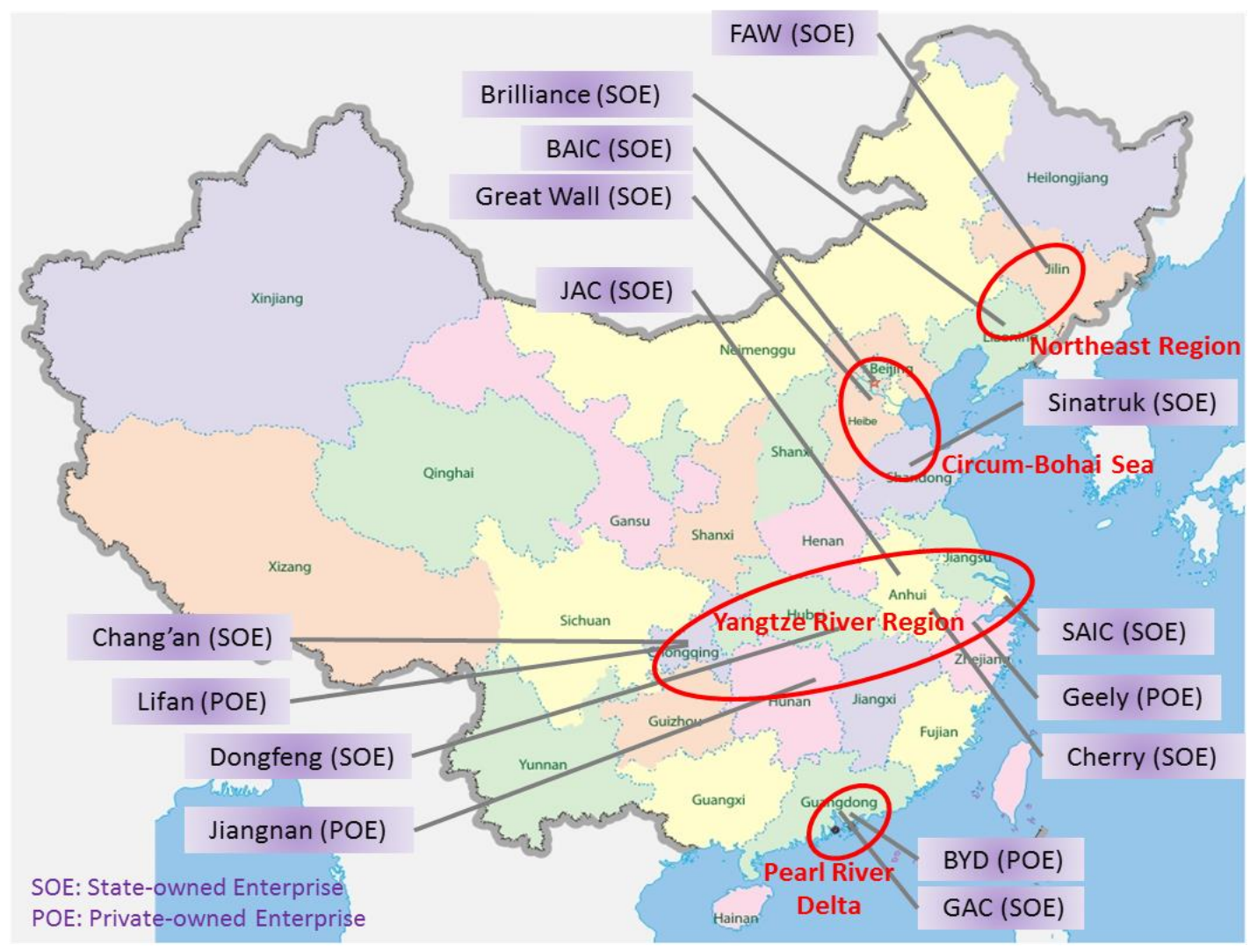

Fig. 17. The headquarter locations of primary automakers (top 15 by sales in 2015)

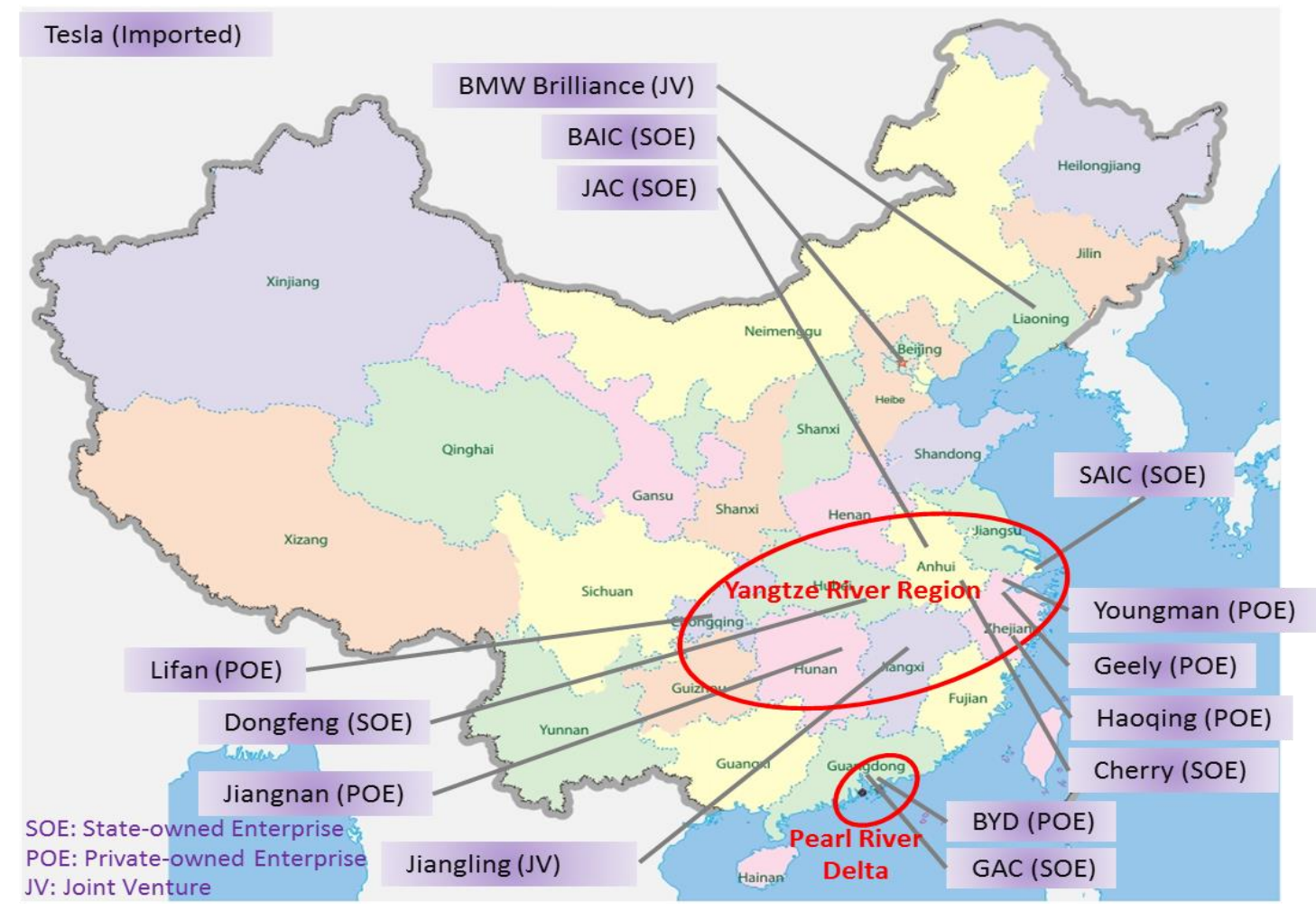

Fig. 18. Headquarter locations of primary PEV makers (Top 15 by sales in 2015) 


\subsection{PLUG-IN ELECTRIC VEHICLE MARKET COMPARISON OF CHINA AND THE UNITED STATES}

To help the readers understand the features of China's PEV market, China's PEV market is compared with the market in the U.S. The U.S. is one of the first countries to develop and popularize the alternative fuel vehicles (AFVs) ${ }^{*}$. The AFV is a dedicated, flexible fuel, or dual-fuel vehicle designed to operate on at least one alternative fuel (7). The U.S. has already formed a relatively mature market for these diverse AFVs including various PEVs.

According to the Alternative Fuels Data Center in the U.S. Department of Energy, nearly 114,000 units consisting of 28 PEV models were sold in the U.S. in 2015, including 71,044 BEVs and 42,825 PHEVs, as seen in Fig. 19 (7). Comparing with the PEV sales in 2014, the PEV sales dropped $4.13 \%$, which might be due to the depressed international oil prices during this year. Different from the small market segment in HEV sales in China, the HEVs have been an essential segment in the U.S. market, and sold 384,404 units consisting of $163 \mathrm{HEV}$ models in 2015. Influenced by the low oil prices, HEV sales dropped $13.39 \%$ compared to 2014 (7).

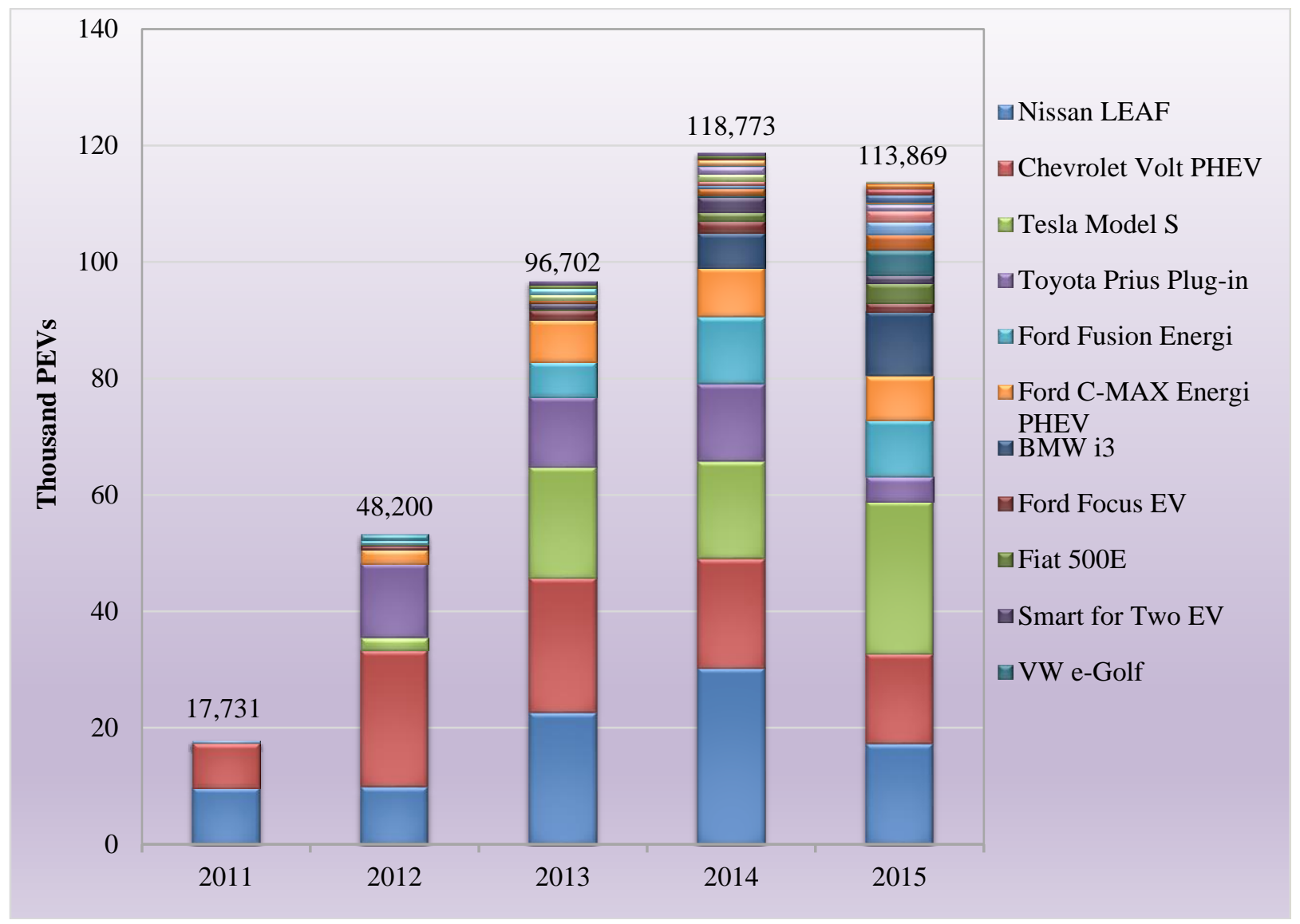

Fig. 19. U.S. plug-in electric vehicle sales by model (7)

\footnotetext{
* According to the U.S. Energy Policy Act of 1992, the alternative fuel ranges from biodiesel, natural gas, propane, electricity, hydrogen, E85, methanol, to coal-derived etc. (http://www.afdc.energy.gov/pdfs/2527.pdf)
} 
In 2015, 15 BEV models and 13 PHEV models from 14 OEMs were sold in the U.S. market (7). The ten best-selling PEV models in the U.S. are shown in Table 3. One is a large-size car (Tesla), two are midsize cars (Ford Fusion Energi and Toyota Prius Plug-in), and the other seven models are compact / subcompact cars. Different from Chinese buyers who prefer inexpensive small-size PEVs (all ten bestselling PEV models in China are cheap Class A or smaller size models), the preferences of the U.S. buyers are more diverse.

On the one hand, the compact (Class A) size PEVs with less electric driving range and cheaper price are the first choice for the both Chinese and U.S. buyers in the respective market. It indicates that the high PEV manufacturing cost and short driving range (insufficient specific energy density of battery) are still significant limitations to the promotion of the PEVs in both markets (8).

On the other hand, the luxury class is a substantial segment in the U.S. PEV market, where the units of luxury cars reached $32.7 \%$ of all light PEVs in 2015.The Tesla Model S became the most popular PEV model in the U.S. Analyzing the ten best-selling PEV models in Fig. 20, the vehicles purchased are segmented by diversified sizes (compact, middle, large size) with MSRP ranging from $\$ 25,120$ to $\$ 69,900$ USD (basic model MSRP before tax credits), and with median MSRP at \$32,375 USD. In general, the PEVs are viewed as a high-status symbol, and therefore after-subsidy high prices are acceptable to the consumers and luxury PEV models are embraced in U.S. market (9).

Table 3. Ten best-selling plug-in electric vehicle models in the U.S., 2015 (7)

\begin{tabular}{|r|r|r|r|r|}
\hline Rank & Model & Type & Class & Electric Range (mi) \\
\hline $\mathbf{1}$ & Tesla Model S & BEV & Large-size (Luxury) & 253 \\
\hline $\mathbf{2}$ & Nissan LEAF & BEV & Compact & 107 \\
\hline $\mathbf{3}$ & Chevrolet Volt PHEV & PHEV & Compact & 53 \\
\hline $\mathbf{4}$ & BMW i3 & BEV & Subcompact(Luxury) & 81 \\
\hline $\mathbf{5}$ & Ford Fusion Energi & PHEV & Mid-size & 21 \\
\hline $\mathbf{6}$ & Ford C-MAX Energi PHEV & PHEV & Compact & 21 \\
\hline $\mathbf{7}$ & VW e-Golf & BEV & Compact & 83 \\
\hline $\mathbf{8}$ & Toyota Prius Plug-in & PHEV & Mid-size & 11 \\
\hline $\mathbf{9}$ & Fiat 500E & BEV & Subcompact & 87 \\
\hline $\mathbf{1 0}$ & Chevrolet Spark & BEV & Subcompact & 82 \\
\hline
\end{tabular}

In China's ten best-selling PEV models in Fig. 12, the PEV market is less differentiated —all best-selling PEV models are compact or smaller size with the MSRP varying from $¥ 108,800 \mathrm{CNY}$ (\$16,767 USD) to $¥ 251,300 \mathrm{CNY}$ (\$38,727 USD) (basic model MSRP without subsidies), and with the median MSRP at $¥ 164,350 \mathrm{CNY}$ (\$25,327 USD). Compared to the U.S. consumers who are less burdened by the higher PEV price premium, the Chinese consumers are more sensitive to the PEV prices. In China, the government subsidies and strict restrictions to conventional vehicles in metropolises are non-negligible factors that gravitate the first-time Chinese vehicle consumers toward PEVs rather than conventional vehicles. At the same time, from the China's domestic PEV makers' perspective, as new players in this 
emerging market segment, most domestic PEV makers barely have the capabilities (advanced PEV technology, pioneering brands, marketing strategy, etc.) to promote the value propositions for their PEV models at the current phase. The premium segment in China's PEV market is dominated by the foreign brands such as Tesla or BMW.

Though less willingness to pay in the PEV market, Chinese car consumers' purchasing capability should not be ignored. China was already the second largest premium car market after the U.S. in 2015. The Mckinsey \& Company expected that China would overtake the U.S. as the largest premium car market as early as $2016^{*}$.

Unlike China's PEV market where the young private-owned automakers were the front-runners in 2015, the U.S. PEV market is dominated by the well-known multinational auto firms. As seen in Fig. 20 a) with the exception of the Tesla Model S, all other PEV models were sold by the traditional top-tier automakers in conventional vehicles. The PEV market in the U.S. is highly concentrated. Fig. 20 b) shows that the PEV market shares have achieved as high as $90 \%$ by 10 models from 7 automakers (Nissan, GM, Tesla, Toyota, Ford, BMW, and Fiat-Chrysler) who have ruled the conventional vehicle market and invested into the PEV technologies for years.

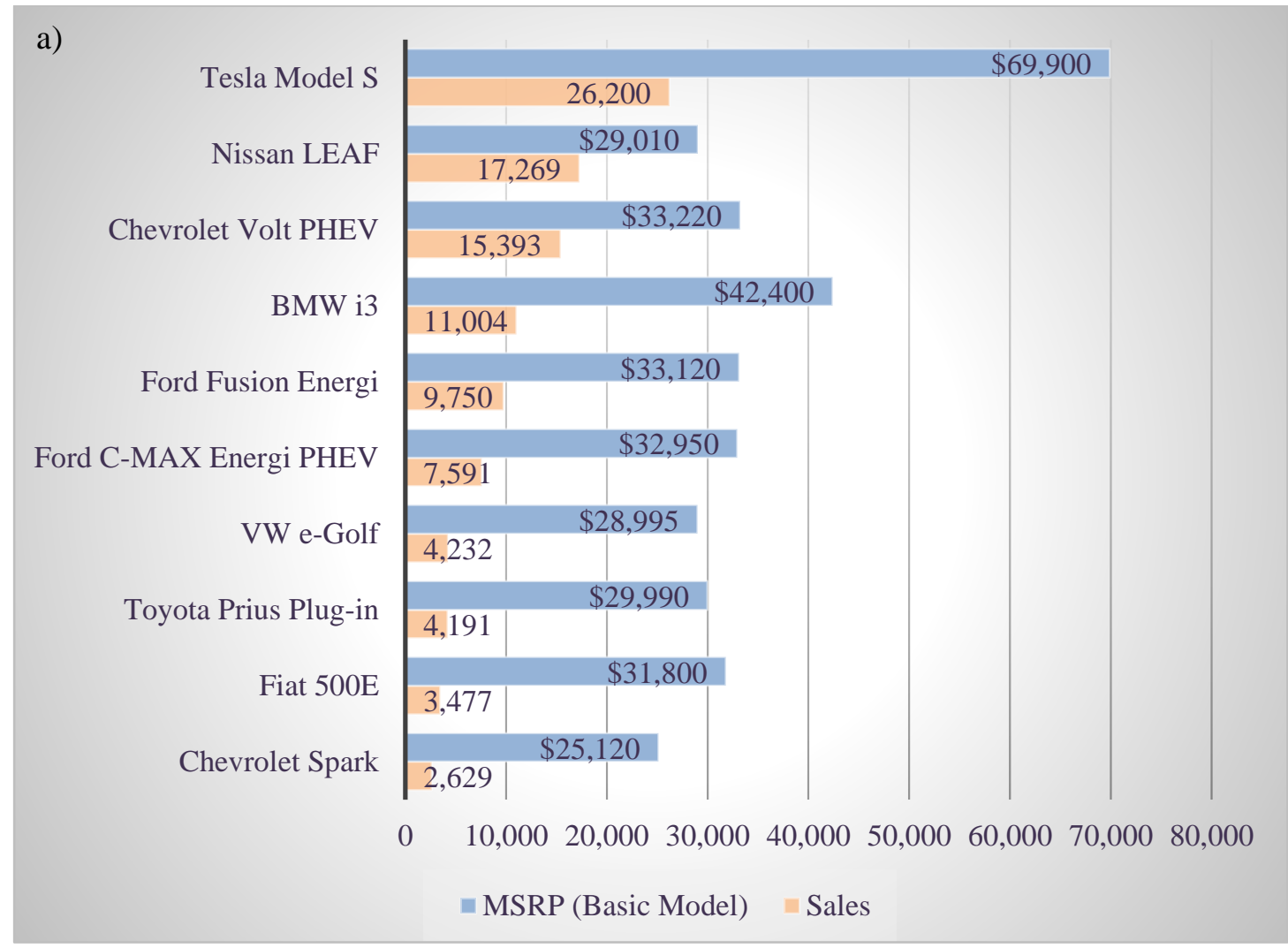

\footnotetext{
* Sha et al. Mckinsey\&Comapny 2016. Upward Mobility: The Future of China's Premium Car Market. http://www.mckinsey.com/ /media/mckinsey/global\%20themes/asia\%20pacific/getting\%20to\%20know\%20chinas \%20premium $\% 20 \mathrm{car} \% 20$ market/upward_mobility the_future_of_chinas_premium_car_market.ashx. Shanghai, China.
} 


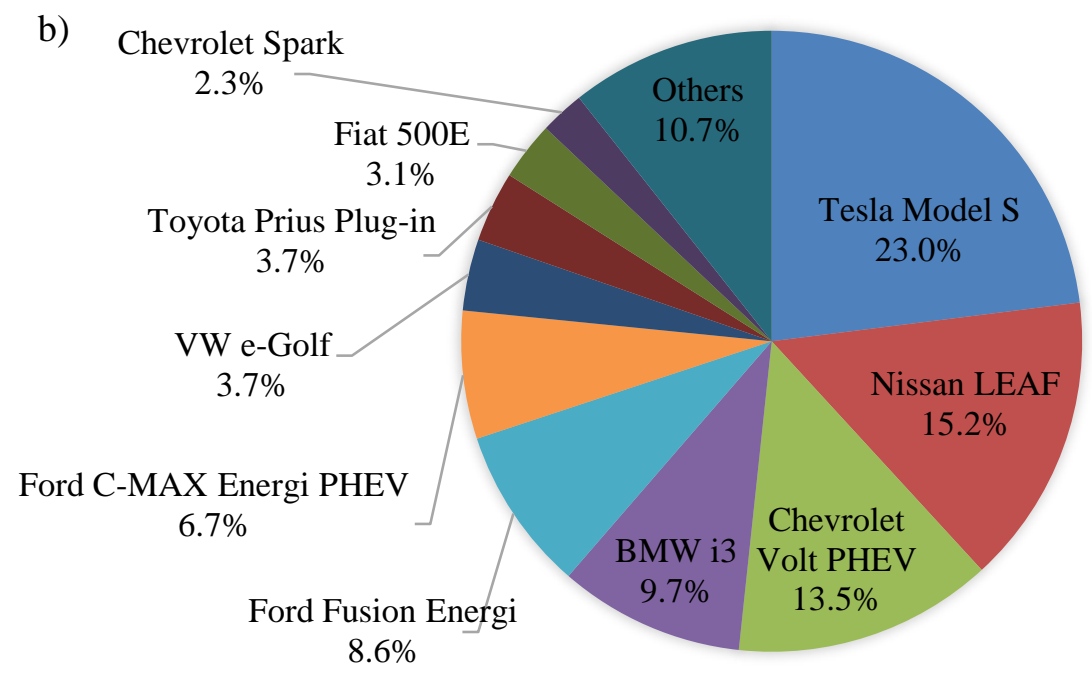

Fig. 20. a) Sales \& prices for ten best-selling PEV models in the U.S. market, 2015 * (7); b) U.S. new PEV market share by model, 2015

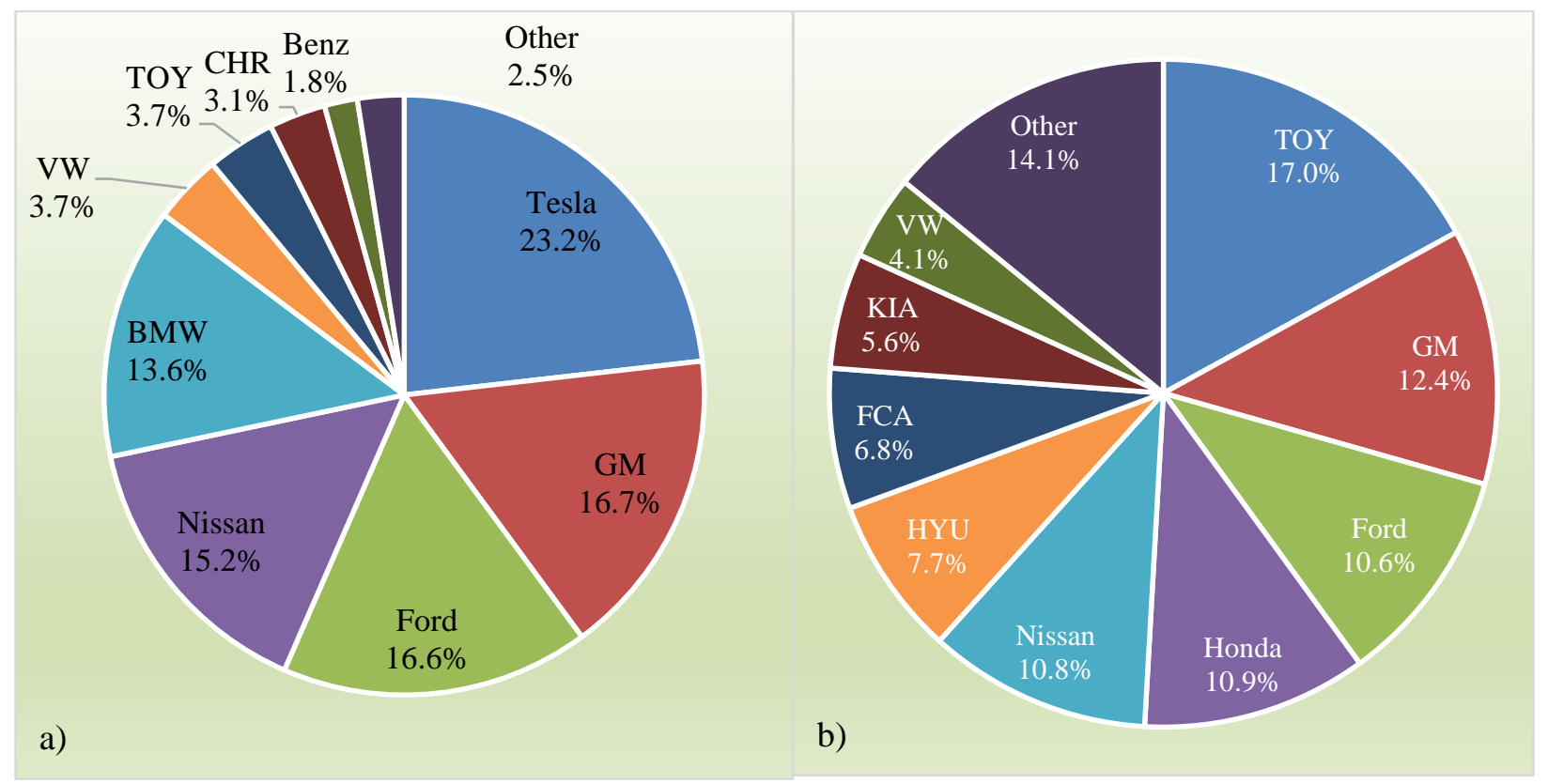

Fig. 21. a) U.S. new PEV market share by manufacturer, 2015 (7); b) U.S. new passenger car market share by manufacturer, 2015 (9)

Meanwhile, both American and Chinese domestic automakers have very good sales performance in respective PEV markets. In the U.S., the sales by domestic automakers (Tesla, GM, Ford, and Chrysler) took over $59.6 \%$ of the light PEV market are shown in Fig. 21. The overwhelming majority of PEVs in China were sold by the domestic automakers. However, the reasons for this similarity might be different. In the U.S, the federal incentives are equal to both domestic and imported PEVs, and the domestic and foreign automakers equally compete in the PEV market. In China, few imported PEVs obtain government subsidies. The PEVs by the domestic automakers have competitive advantages in price with subsidies and

* The MSRPs are for the 2015 basic models. 
become are more attractive to the Chinese PEV buyers who are sensitive to prices. Thus, multinational OEMs have to make their PEVs in their joint-venture plants in China to obtain the government subsidies. Though facing the trade barriers, the interests of the multinational automakers seem never damped, noting that most of them have had business plans in the glamorous Chinese market.

\subsection{MICRO EVS: MOST WELCOMED PLUG-IN ELECTRIC VEHICLES}

With the prosperity of the PEV market in China, the official micro EVs (A00) have become the bestselling PEV class in 2015. According to the CATARC, the sales of the Class A00 models have $33.7 \%$ of the PEV market, and $66.2 \%$ in the electric passenger car market in 2015 (2). Five models out of the 20 best-selling PEVs in 2015 are micro EVs (A00) (2). The explosive growth of the micro EVs sales contributes $51.9 \%$ of all the new plug-in electric passenger car sales growth, with the sales of micro EVs having increased $378 \%$ in 2015 compared with the sales in 2014 (see in Fig. 22). The Technical Specifications of the New Energy Vehicle by Central Government Subsidies (新能源汽车产品技术要求 )*, which was issued by the National Development and Reform Commission and the MIIT in April 2015, has given specific requirements to PEVs that are qualified for the subsidies in 2016-2020. This announcement raised specification demands on vehicle dynamics, weights, and energy economy. For instance, the maximum speed for a PEV is required to be higher than $100 \mathrm{~km} / \mathrm{h}(62 \mathrm{mph})$, and the electric range is required to be longer than $100 \mathrm{~km}$ (62 miles).

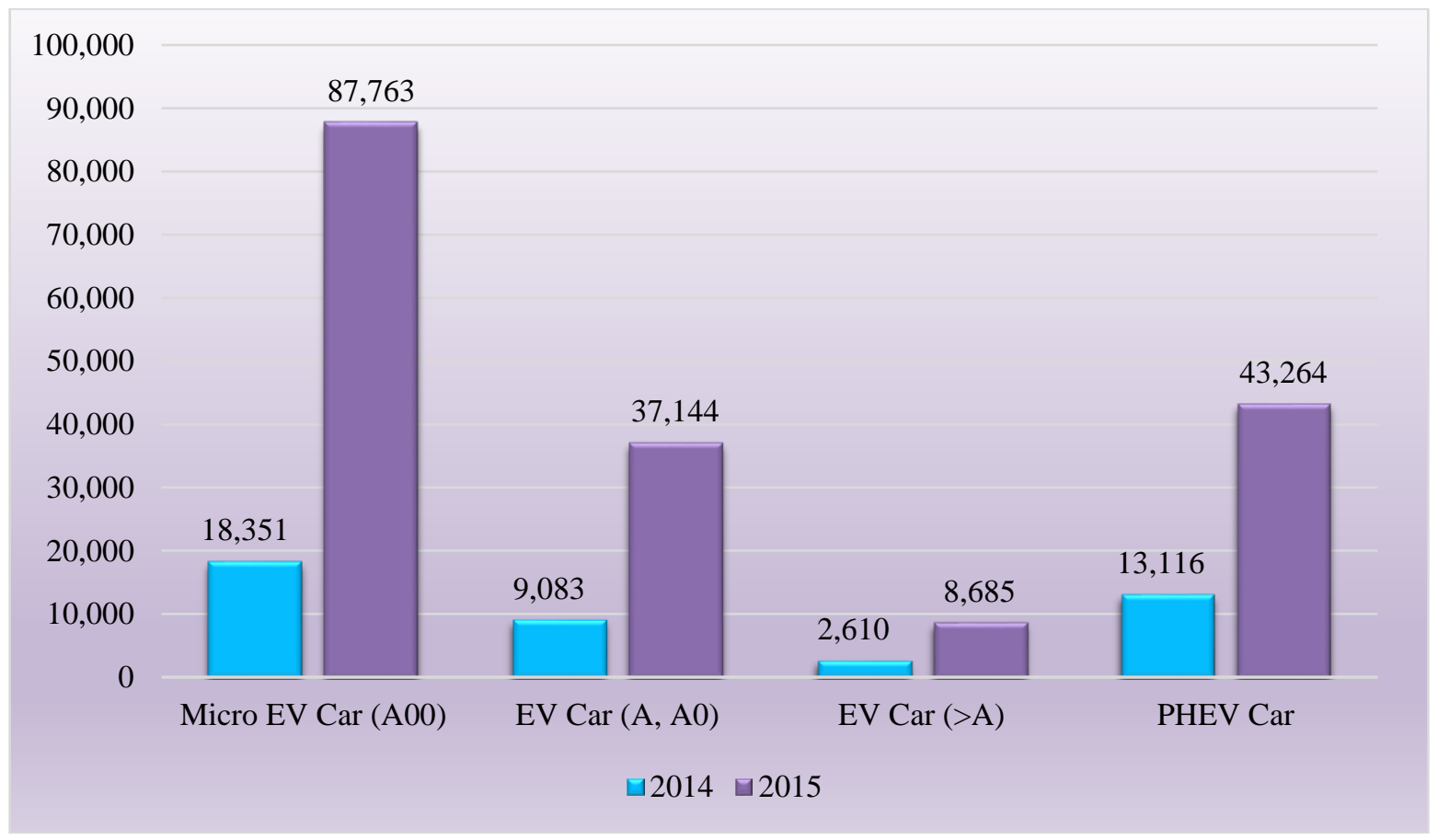

Fig. 22. Passenger plug-in electric vehicles sales by classifications, 2014 and 2015 (2)

\footnotetext{
* Source by http://www.miit.gov.cn/n1146290/n4388791/c4214459/content.html (in Chinese)
} 
Except for the official micro EVs, the units of the unofficial EVs that are not qualified under the government requirements are also tremendous in China. As it was mentioned in Section 1.1, LSEVs or unofficial micro EVs were not counted in PEV statistics by CATARC, yet they are highly accepted in suburb or rural areas in China, and cater to the low-income class who want to own their own cars as well. By 2015, there have been more than 100 LSEV makers in China. Per Fang \& Zhu's report on China LSEV market, the annual production capability of LSEVs reached 2 million units in 2014 (10).

It is still controversial to develop LSEVs, or unofficial micro EVs, in China. Since the LSEVs or unofficial micro EVs are positioned for the consumer group in the low-income class from rural and suburb areas, various inexpensive components are assembled in the LSEVs or unofficial micro EVs to reduce the manufacturing costs, such as: adopting high-polluted lead-acid batteries and low-cost small brushless DC (Direct Current) motors in the vehicle powertrains; simplifying vehicle safety and protection equipment; or reducing component specifications. The buyers rarely register for their unofficial micro EVs or have training before driving on the road, which brings public risks and administrative costs to the government. Some local governments categorize the LSEV or unofficial micro EVs into electric scooters or electric carts / neighborhood vehicles, and ban road use to these vehicles. These unofficial EVs are not able to obtain government subsidies. For example, in a southern Chinese city of Shenzhen, the e-bikes or other LSEVs which are claimed as "silent killers" have been banned by municipalities since 2011*. On the other hand, because of the market demands, 18 provinces in China have approved some unofficial micro EVs or LSEVs as passenger vehicles to meet the market demands as of May, $2015^{\dagger}$. Shandong is the largest province in terms of micro EV production in China (10). Based on the statistics of Shandong Economics and Information Technology Committee, 20 major LSEV makers produced around 215,000 LSEVs in year 2014 compared to only 68,400 units in year 2011 (see Fig. 23.)

Targeting the low-income consumers, the extremely cheap prices of these unofficial micro EVs are a decisive competitive advantage. The actual price of the unofficial micro EVs for buyers range from $¥$ $30,000 \mathrm{CNY}$ (\$4,623 USD) and 70,000 CNY (\$10,787 USD), which is very attractive to the Chinese consumers who cannot afford a conventional car (10). Though these unofficial micro EVs or LSEVs are not recognized by the government as official PEVs, their expanded market is changing the PEV industry. With less technical barriers, this low-margin and high-volume business is attractive to many manufacturing firms, especially private capitals looking to invest. What's more important, the wide popularity of these inexpensive micro EVs is certainly conducive to developing societal recognition and EV driving habits, and offering a cheap mobility mode to middle or lower income buyers from suburb/rural areas in China. According to a Sohu Auto investigation, $70 \%$ of respondents had good knowledge or basic knowledge on the LSEVs/micro EVs (10). The extensive cognitions of PEVs and PEV driving habits are necessary for the sustainable growth of the PEV market in the future.

Realizing the large capacity of LSEVs/micro EVs by the manufacturing firms, the Chinese government has started to regulate the development of this industry. Although the national standard for the LSEVs/micro EVs will not be out soon, the central government encourages the provincial industrial associations to build their own standards first, and the MIIT has planned a study on the national standard.

\footnotetext{
* Josh Chin. The Wall Street Journal. 2011. "Shenzhen Takes on China's 'Silent Killer'”. http://blogs.wsj.com/chinarealtime/2011/06/20/shenzhen-takes-on-chinas-silent-killer/ (visited in September, 2016)

$\dagger$ Hua Chuang Securities, “Summary: The Study for New Energy Vehicle Industry Chain (综述: 新能源汽车全产业链深度研 究)” http://nev.ofweek.com/2016-01/ART-71008-8420-29049413_2.html (in Chinese) (visited in April, 2016)
} 
Approved by the State Council in June 2015, the Provisions on the Administration of Newly Established Pure Electric Passenger Vehicle Enterprises (新建纯电动乘用车企业管理规定) ${ }^{*}$ supports

manufacturers who upgrade their production lines to be qualified EV makers. The manufacturers who used to produce LSEVs or e-bikes could seize the opportunity to produce competitive certified PEVs and obtain government subsidies as well. For example, Kandi used to be a private-owned manufacturer primarily building neighborhood vehicles, LSEVs, or rural vehicles. With the government incentives, Kandi has upgraded its production line and built more than 25,000 units of BEVs in 2015 (2).

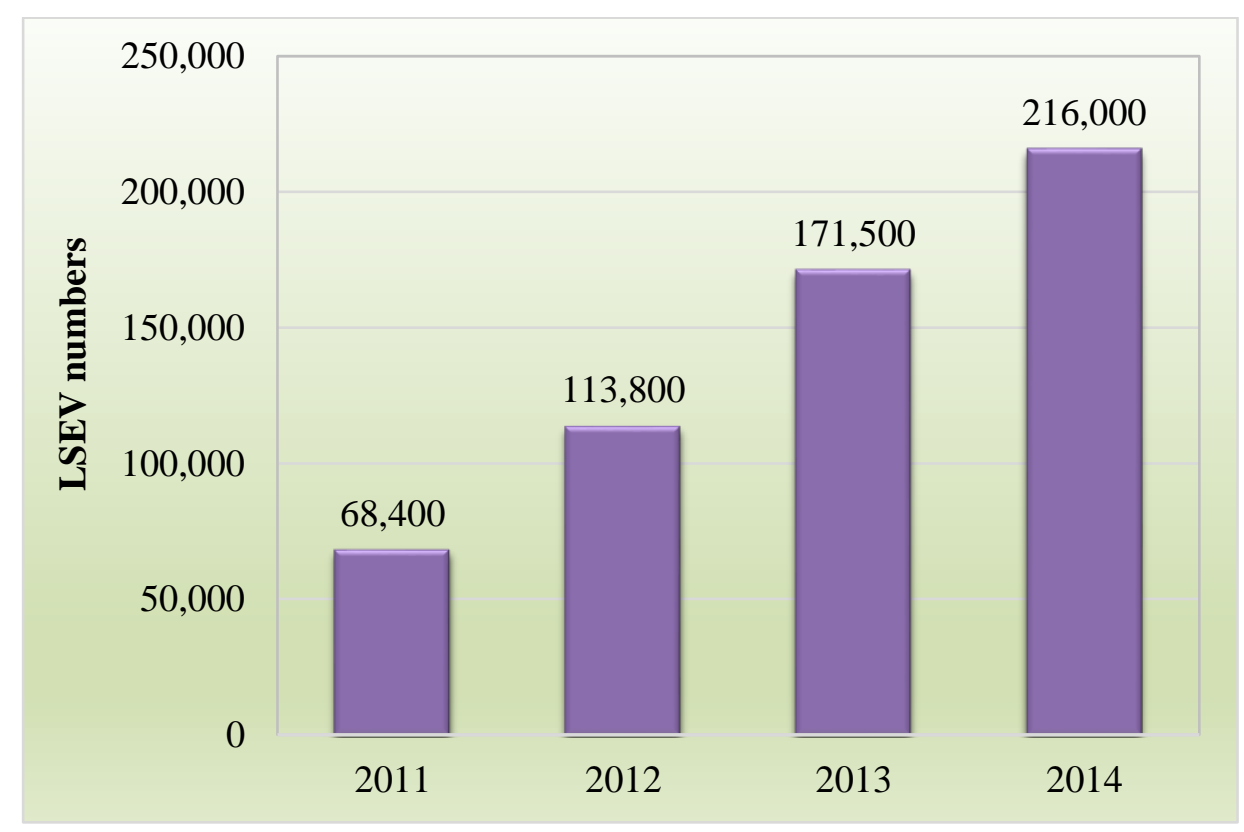

Fig. 23. LSEV production from twenty major LSEV makers in Shandong province, 2011-2014 (10)

\subsection{MULTINATIONAL INVESTMENTS IN CHINA'S PLUG-IN ELECTRIC VEHICLE MARKET}

The Chinese government issued the Catalogue of Industries for Guiding Foreign Investment (外商投资 产业指导目录) in 2011, which encourages the international capitals to join the PEV industry or related key components manufacturing-especially EV battery development ${ }^{\dagger}$.

Though the domestic OEMs dominated China's PEV market in 2015, the products by foreign automakers are highly competitive still. Lacking the design, quality control and EV battery technologies, the domestic firms remain in the low-end segment. The foreign brands monopolize the high-end class in the PEV market. For example, although the Tesla Model S is not qualified for Chinese government subsidies, they still sold 3,692 units and ranked 13th in the PEV sales in 2015. China has been viewed by Tesla as an

\footnotetext{
${ }^{*}$ Source by http://www.sdpc.gov.cn/zcfb/zcfbl/201506/W020150604631327281089.pdf (in Chinese)

$\dagger$ Hui Wu. Ccid Consulting, 2013. "The Strategy Study for the Foreign-owned Enterprises into China New Energy Vehicle Industry" (in Chinese), http://www.itdcw.com/archives/news/041U3412013.html (visited in July 2016)
} 
essential market which contributed $30 \% \sim 35 \%$ to Tesla's global sales*. Other premium brands such as BMW, Mercedes Benz, and Volvo cars also have PEV sales in China.

With the barriers to obtain government subsidies, the price competitiveness of imported PEVs is further weakened by the import tariff. However, the government fiscal subsidies will be gradually reduced and completely withdrawn after 2020, thus the price gap between domestic PEVs and imported PEVs will be closer. For the foreign automakers, their PEV products assembled in their joint venture plants in China will be eligible to obtain government subsidies. For example, Nissan is producing the BEV modelVenucia EV (the Chinese version of Nissan Leaf) in its joint venture in China. The Venucia EVs obtained the government subsidies and were sold 984 units in China in 2015 (2). Many first-tier multinational automakers have had plans to expand the PEV production domestically with the growing PEV acceptance of Chinese consumers. For example, in June 2015, the Volkswagen (VW) Group China and the SAIC Motors signed an agreement to invest $¥ 6.5$ billion CNY ( $\$ 1.00$ billion USD) into PEV production in Shanghai. The VW Group plans to invest ¥22 billion CNY ( $\$ 3.39$ billion USD) into the Chinese automotive market by 2019 which will be the largest investment in the Chinese automotive industry ${ }^{\dagger}$. General Motors plans to collaborate with the Pan Asia Technical Automotive Center and will release a PHEV model in China in 2018. Fig. 24 shows the statistics of the PEV models which are planned to be imported to the Chinese market by the foreign OEMs in 2016 to 2020. Compared with the domestic PEV models in Fig. 16, more than half of the imported PEVs adopt the PHEV as their technology type and most of the imported PEVs have vehicle size class B or above. The multinational automakers will more actively participate into the competition of China's PEV market, especially in the high-end PEV segment, in next few years.

\footnotetext{
* Source by Deloitte and the Ministry of Commerce of the People's Republic of China, 2014. "2014 China Automotive Industry Investment Promotion Report" (in Chinese). Beijing, China.

$\dagger 21$ th Century Economics, 2015. “VW Groups Started Its 6.5 Billion RMB Investment in China (大众在华启动 65 亿元投资)” (in Chinese), http://www.diandong.com/news/201512215167.shtml (visited in July 2016)

¥ Source: http://energy.gov/eere/vehicles/fact-918-march-28-2016-global-plug-light-vehicle-sales-increased-about-80-2015 Data compiled by Argonne National Laboratory, Argonne, IL, February 2016.
} 


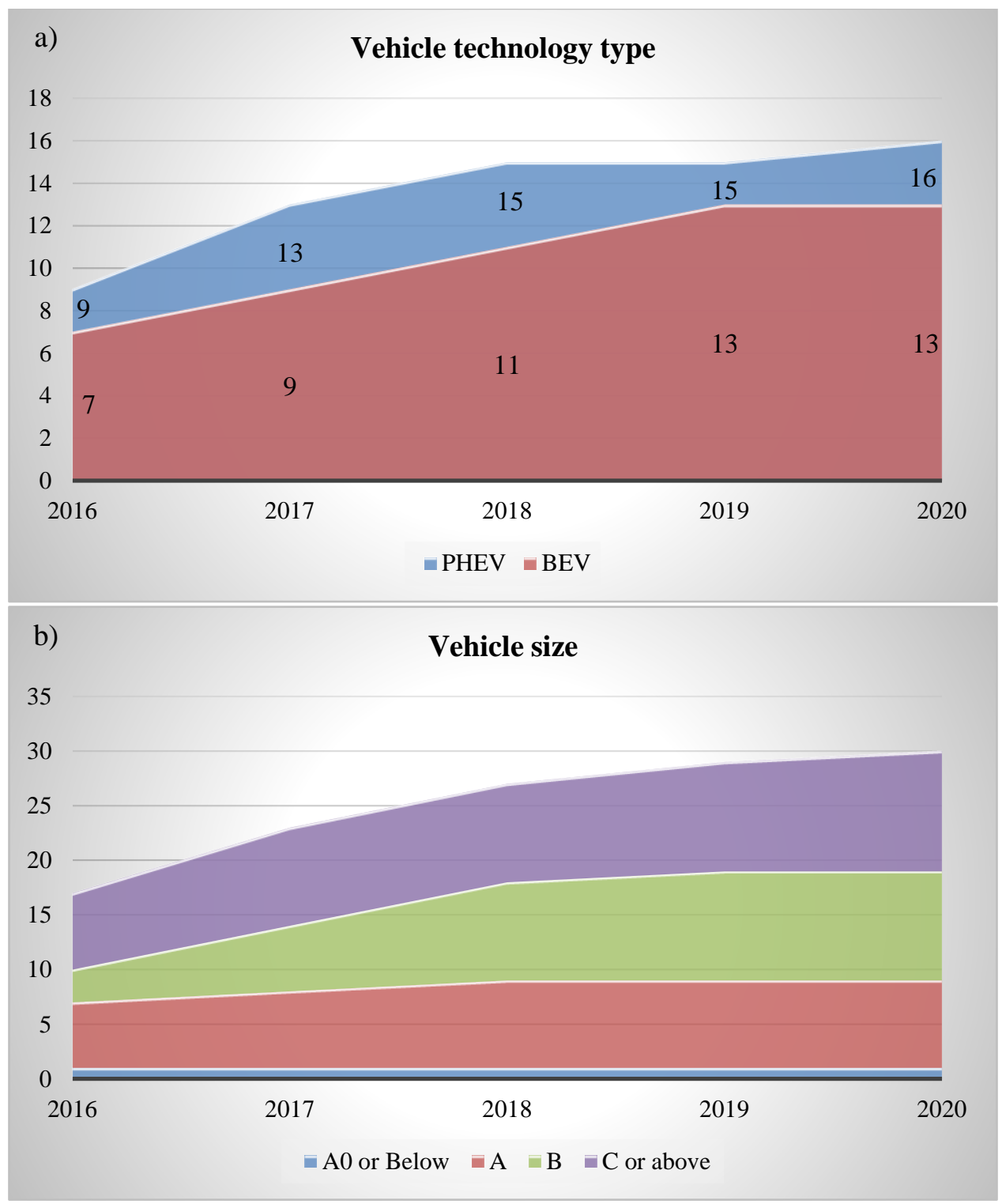

Fig. 24. a) Model units of the imported passenger PEVs by technology type in 2016-2020; b) model units of the imported passenger PEVs by vehicle size in 2016-2020 (2) 


\section{POLICIES IN THE PLUG-IN ELECTRIC VEHICLE MARKET}

\subsection{POLICIES OF THE CENTRAL GOVERNMENT IN 2012-2015}

China has used various incentives such as the R\&D grants/funding, lenient policies, and government procurement to push forward the PEV development. Specifically, the PEV has been regarded as the national strategic industry by the "Twelfth Five-year" Plan for the National Development of Strategic Emerging Industries by the State Council in 2012*. The society of China is experiencing economy reform through the growth of the domestic demands and the manufacturing sector deceleration. The government expects the domestic PEV industry to realize the indigenous innovation, technology advancement that will boost the domestic demands. Several guideline policies were carried out by the central government to motivate the development of the PEV industry. The primary guideline policies are shown in Table 4. More major national policies or events in the PEV industry are given in the Appendix A.

Table 4. Primary Government Guidelines in the PEV Industry

Government Guideline Document

Planning for the Development of the Energy-Saving and New Energy Automobile Industry (2012-2020) ${ }^{\dagger}$

Accelerating the Promotion and Application of New-energy Automobiles

Made in China 2025 §

Guiding Opinions on Accelerating the Construction of Electric Vehicle Charging Infrastructure **

\section{Date}

June 2012

July 2014

May 2015

September 2015

In general, the government PEV monetary incentives can be divided chronologically into three phases.

- 2009 - 2012: The government carried out the "Ten Cities - Thousand Vehicles" demonstration program (十城千辆工程) which encouraged the sale of thousands of PEVs in ten cities each year through monetary incentives and government procurement. Most of the PEVs procured in this program were used as public fleet vehicles (such as public bus transits, taxis, government vehicles, sanitation vehicles or poster services). The private consumers were not eligible for the government subsidies in most cities until 6 cities extended the subsidies to both public and private buyers in the latter phase of this program. Notably, the HEVs also qualified to obtain the government subsidies which was $¥ 3,000 \mathrm{CNY}$ (\$462 USD) in this phase. By the end of the program in 2012, the number of PEV units sold were far from meeting its first stated target of a half million units by 2011 (4).

- 2013 - 2015: The central government extended incentives to all vehicle purchasers including public fleets and individual buyers. In 2013, the Ministry of Finance offered the new subsidies for the NEVs for the next 3 years to continue financially supporting the PEV industry after the "Ten Cities -

\footnotetext{
* Source by http://www.gov.cn/zwgk/2012-07/20/content 2187770.htm (in Chinese)

$\dagger$ Source by http://www.ycdpc.gov.cn/ywgl/gyfz/201204/W020120508580846293516.pdf (in Chinese)

* Source by http://www.gov.cn/zhengce/content/2014-07/21/content_8936.htm (in Chinese)

$\S$ Source by http://www.gov.cn/zhengce/content/2015-05/19/content 9784.htm (in Chinese)

*** Source by http://www.gov.cn/zhengce/content/2015-10/09/content_10214.htm (in Chinese)
} 
Thousand Vehicles" program* concluded. The other central ministries and provincial governments also carried out a series of incentives and policies for vehicles sales and OEMs to stimulate the growth of the PEV market, but HEVs were no longer eligible for any incentives from the government. The Purchase Tax Catalogue was issued in 2014 which exempted all the PEVs from the vehicle purchase tax. The industrial standards for EV charging and infrastructures were issued as well. During this period, vast private capitals were attracted by the incentives and flooded into the PEV industry.

- 2016 -2020: The government issued a financial subsidies plan in 2015 with plans for the subsidies to be phased out over time; and will carry out non-monetary incentives for the PEV industry sustainable development. The PEV subsidy fraud has drawn attention by the central government and motivates the government to be more prudential about offering monetary incentives. To regulate the qualified PEVs, the government repealed the old Subsidy Catalogue and required all automakers to re-submit their vehicle models for subsidies in 2016. At the same time, the non-monetary incentives such as the draft of the regulations for the CAFC (cooperate average fuel consumption) Credits and New Energy Vehicle Credits were published by the government, which will gradually replace the government subsidies ${ }^{\dagger}$.

It is believed that China's PEV sales in recent years have been driven by the government's policies and incentives (11). It was 2014 that the PEV market growth started to accelerate, when massive incentives were implemented. In February 2014, the State Council announced that some qualified PEV models are exempted from the vehicle purchase tax which typically ranges from $1.0 \%$ to $40 \%$ of a vehicle's MSRP:. In May 2014, the president of China, Jinping Xi, visited a PEV company in Shanghai and stressed that the development of PEVs will be the key for the Chinese automotive industry. In July 2014, the Chinese PEV models were listed in the directory for government vehicle purchase. In the same month, the subsidy policy for EV charging was issued. A national incentive for EV charging infrastructure was issued in November 2014. Also in November 2014, the consumption tax of petroleum products was increased, which drove up the gasoline/diesel prices. Therefore, in addition to analyzing the sales and production in the Chinese PEV market, it is necessary to explore the relationships between PEV sales and incentives in specific cases due to the significant influence of the policies.

In the meantime, the generous subsidies and regulation loopholes draw criticism about wasting money and create fraud by automakers. The public doubts that the unusual growth of the PEV production and sales in 2015 is unadulterated§. In early 2016, the government has launched investigations to verify the product qualities and sales units supplied by the automotive makers**.

\footnotetext{
* Source by http://www.gov.cn/zwgk/2013-09/17/content_2490108.htm (in Chinese)

† Source by http://www.miit.gov.cn/n1146295/n1652858/n1653100/n3767755/c5261365/content.html (in Chinese)

* Source by http://www.chinatax.gov.cn/n810341/n810765/n812171/n812695/c1191404/content.html (in Chinese)

$\S$ Bertel Schmitt. Forbes, 2016. "Large Number of Chinese EV Sales Fake, Investigators Say",

http://www.forbes.com/sites/bertelschmitt/2016/02/01/large-number-of-chinese-ev-sales-fake-investigators-say/\#5c0fb25f4dc3

${ }^{* *}$ Source by the Equipment Industry Division in the Ministry of Industry and Information Technology of P.R. China,

"Notification of the Verification for the New Energy Vehicle Development Work"

http://www.miit.gov.cn/n1146285/n1146352/n3054355/n3057585/n3057592/c4608474/content.html (in Chinese)
} 


\subsubsection{Government Subsidies in Light-Duty PEVs (passenger plug-in electric cars)}

The central government subsidies from 2013 to 2015 to the new energy passenger cars are shown in Table 5. The only technical specification for the subsidy evaluation criteria is the electric range which is dependent on the battery technologies. The authorities encouraged purchases from the government organizations, public transit systems, and public service institutes. Though the subsidy targets were for PEV buyers, the appropriation was directly allocated to the PEV OEMs, thus the actual price that the buyers paid for PEVs was reduced by the subsidies. This subsidy model mitigates the PEV consumer's financial burdens immediately and elevated the attractiveness of the PEVs. However, as required by the government, the total amount of the subsidies for a PEV should have been less than $60 \%$ of the PEV $\operatorname{MSRP}(10)$.

Table 5. Central government subsidies for electrified passenger cars, 2013-2015*,

\begin{tabular}{|c|c|c|c|c|}
\hline Type & $\begin{array}{l}\text { Electric } \\
\text { Range }\end{array}$ & 2013 & 2014 & 2015 \\
\hline $\begin{array}{l}\text { Plug-in Hybrid Electric Car (Includes } \\
\text { Extended Range EV) }\end{array}$ & $>50 \mathrm{Km}$ & $\begin{array}{l}Y 35,000 \\
(\$ 5,394)\end{array}$ & $\begin{array}{l}¥ 33,250 \\
(\$ 5,124)\end{array}$ & $\begin{array}{l}¥ 31,500 \\
(\$ 4,854)\end{array}$ \\
\hline \multirow{3}{*}{ Battery Electric Car } & $80-150 \mathrm{Km}$ & $\begin{array}{l}Y 35,000 \\
(\$ 5,394)\end{array}$ & $\begin{array}{l}Y 33,250 \\
(\$ 5,124)\end{array}$ & $\begin{array}{l}Y 31,500 \\
(\$ 4,854)\end{array}$ \\
\hline & $150-250 \mathrm{Km}$ & $\begin{array}{l}¥ 50,000 \\
(\$ 7,705)\end{array}$ & $\begin{array}{l}¥ 47,500 \\
(\$ 7,320)\end{array}$ & $\begin{array}{l}¥ 45,000 \\
(\$ 6,935)\end{array}$ \\
\hline & $>250 \mathrm{Km}$ & $\begin{array}{l}Y 60,000 \\
(\$ 9,246)\end{array}$ & $\begin{array}{l}Y 57,000 \\
(\$ 8,784)\end{array}$ & $\begin{array}{l}¥ 54,000 \\
(\$ 8,322)\end{array}$ \\
\hline \multicolumn{2}{|l|}{ Fuel Cell Electric Car } & $\begin{array}{l}¥ 200,000 \\
(\$ 30,821)\end{array}$ & $\begin{array}{l}¥ 190,000 \\
(\$ 29,280)\end{array}$ & $\begin{array}{l}¥ 180,000 \\
(\$ 27,739)\end{array}$ \\
\hline
\end{tabular}

The actual PEV sales prices for buyers were greatly reduced with the government subsidies. Fig. 25 shows the comparison of the prices with subsidies for the ten best-selling PEV models in China in 2015. The average percentage of subsidies for these BEV models in Fig. 25 is $51.1 \%$, which means the consumer paid about half the MSRP for a new BEV. However, the average percent of the subsidies for PHEV models in Fig. 25 is $24.6 \%$. The PHEV models have less subsidies compared with the subsidies for BEV models. The Chinese government prioritizes the development of BEVs instead of the PHEVs. For instance, many provincial governments offer various incentives to the BEVs. The Beijing's municipality subsidizes BEV models only and excludes PHEV models from its city subsidy catalogue, which is deemed to promote the BEVs. This policy is also criticized as being regional protectionism that suppresses the sales of PHEVs from automakers outside of Beijing since BAIC Motors (the largest auto firm in Beijing) only produces BEVs

\footnotetext{
* Source by http://www.most.gov.cn/tztg/201309/t20130917 109405.htm (in Chinese)

$\dagger$ Source by http://www.most.gov.cn/tztg/201402/t20140212_111801.htm (in Chinese)

$\$$ Sohu, 2016. "Former Director of the Planning Division in the Ministry of Industry and Information Technology blamed the New Energy Vehicle Planning in Beijing (原工信部㚘划同处长”炮轰”北京新能原车政策)”, http://auto.sohu.com/20160217/n437613315.shtml (in Chinese)
} 


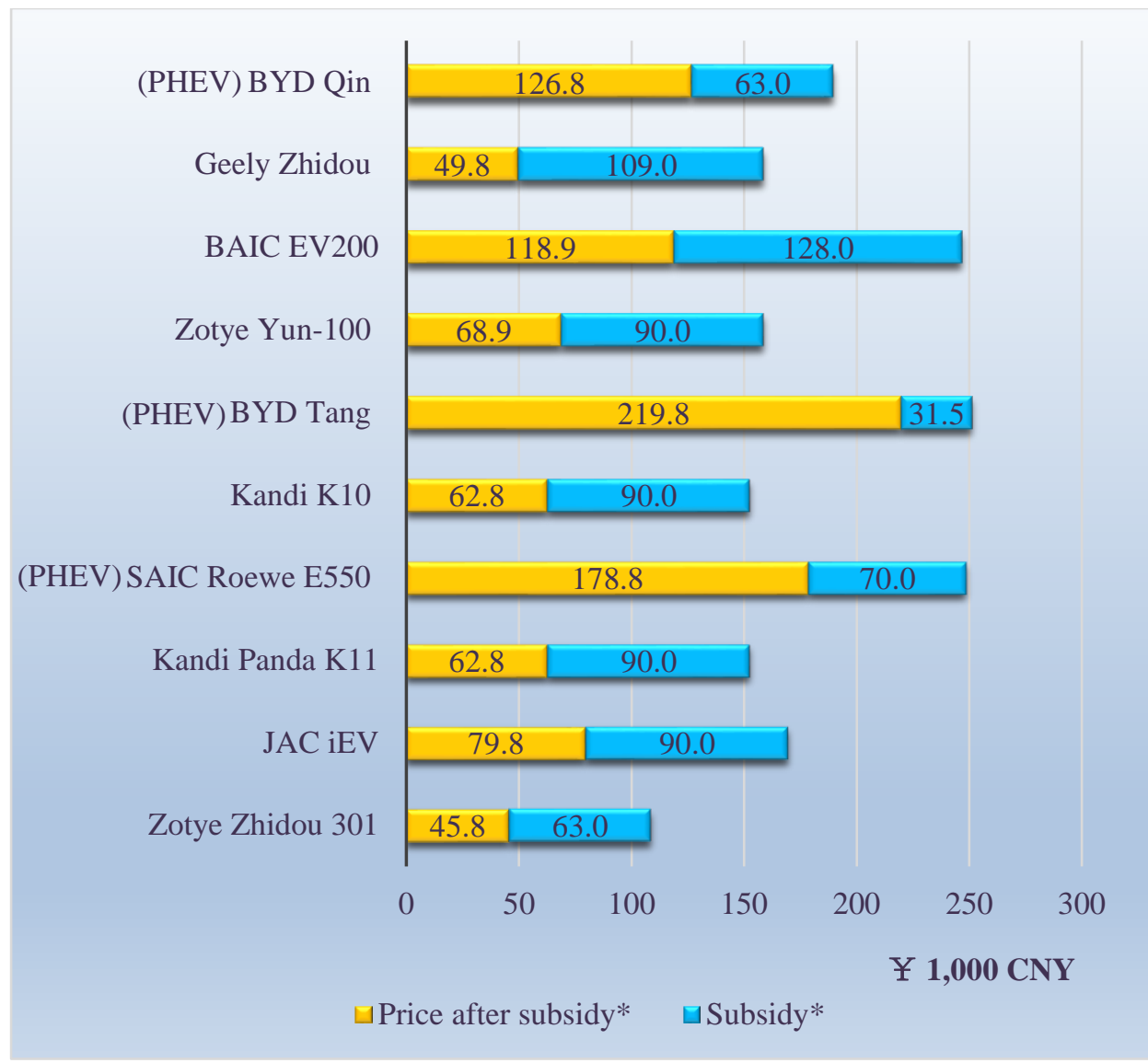

* The value is the sum of maximum subsidies from central government and local government. Different local subsidies vary.

Fig. 25. Prices for ten best-selling PEVs (basic model) in China, 2015 ${ }^{* \dagger}(2)$

Although the low-cost micro (A00) PEVs are generally recognized as low-cost, low-tech and low-quality cars, Fig. 25 shows that the proportion of subsidies for micro EVs might equal to or exceed the proportion of subsidies for PEVs in the larger-size classes. In fact, these micro EVs have taken over $66 \%$ the PEV market according to the statistics by the Ministry of Finance in China ${ }^{\ddagger}$. However, this conclusion is drawn based on the investigation to the ten most popular EVs, more studies are still needed to adequately assess the rationality of the government incentives.

\subsubsection{Government Subsidies in Heavy-Duty PEVs (plug-in electric buses)}

Considering the great demands of the public fleets in China and the abundant procurements by the government, the plug-in electric bus sales are considered as an essential segment in China's PEV market. Table 6 lists the central government subsidies for the new energy buses (BEV/PHEV/FCEV), which shows that the subsidies for electric buses did not decline from 2013 to 2015 like the subsidies for the passenger cars. The subsidies were abundant for the EV bus makers who might also have priority to

\footnotetext{
* Source by D1EV Website, "Electric Vehicles Information Database", http://www.d1ev.com/salecar (in Chinese)

$\dagger$ Shi Chen. A0EV, 2016. “The Best-selling Electric Vehicles in Year 2015”, http://www.aooev.com/html/201601/59439.html (in Chinese)

¥Yue Zhang. Ministry of Finance of PRC 2016. "Why the government should not keep subsidizing the New Energy Vehicles", http://www.mof.gov.cn/zhengwuxinxi/caizhengxinwen/201603/t20160302_1828176.html (in Chinese)
} 
obtain tax exemptions from the government and loans from the state-owned banks. For example, in some cities (e.g., Beijing, Tianjin, Guangzhou etc.), a PEV assembled locally qualifies for the local government's subsidy matched the amount of the subsidy from the central government (10). In these cities, the manufacturer of a 10-meter-long electric bus might have received up to ¥ 1 million CNY (\$154 thousand USD) subsidies per vehicle.

Table 6. Central government subsidies for electrified buses, 2013-2015 ${ }^{*}, \dagger$

\begin{tabular}{|c|c|c|c|c|}
\hline Type & Bus Length & \multicolumn{3}{|c|}{2013 - 2015} \\
\hline $\begin{array}{l}\text { Plug-in Hybrid Electric Bus } \\
\text { (Includes Extended Range EV) }\end{array}$ & $>10$ meters & \multicolumn{3}{|c|}{$¥ 250,000(\$ 38,527)$} \\
\hline & $6-8$ meters & \multicolumn{3}{|c|}{$¥ 300,000(\$ 46,232)$} \\
\hline Floctric Buy & $8-10$ meters & \multicolumn{3}{|c|}{$¥ 400,000(\$ 61,643)$} \\
\hline & $>10$ meters & \multicolumn{3}{|c|}{$¥ 500,000(\$ 77,053)$} \\
\hline \multirow{2}{*}{\multicolumn{2}{|c|}{ Fuel Cell Commercial Vehicle }} & 2013 & 2014 & 2015 \\
\hline & & $\begin{array}{l}500,000 \mathrm{CNY} \\
(\$ 77,053)\end{array}$ & $\begin{array}{c}450,000 \mathrm{CNY} \\
(\$ 69,348)\end{array}$ & $\begin{array}{c}400,000 \mathrm{CNY} \\
(\$ 61,643)\end{array}$ \\
\hline
\end{tabular}

Attracted by numerous subsidies from the government, some PEV makers intentionally raised the vehicle MSRP or falsified sales records to generate their revenue from the subsidies. Frauds were more serious in the electric bus segment ${ }^{+}$It was disclosed by the MIIT that the accumulated PEV sales reached 174,000 for the first ten months in 2015 while the PEV registration numbers were 108,000. That indicates that some produced PEVs that were not on road. Director Xu from the State Information Center in MIIT suspected that these additional PEVs that were not registered might be fictitious and the sales records were used to defraud the government for the subsidies ${ }^{\S}$. Oversimplified incentive policies and loose standards might led to the subsidy fraud which is detrimental to the sustainable development of the PEV market in the long term. The government started an investigation to verify the fraud in the PEV industry in February 2016 and released the initial results to the pubic in early September $2016^{* *}$. In order to avoid excessive subsides, it has been requested by the central government that the total subsidies from both central and local governments not exceed more than $60 \%$ of the MSRP of the vehicle (10). New incentives and subsidy standards have been released in 2016 to amend or replace the old ones.

\subsection{INCENTIVES BY LOCAL GOVERNMENTS}

In addition to the PEV incentives from the central government, local governments take actions to influence the local PEV industry and market. By the end of 2015, the PEV demonstration cities had

\footnotetext{
* Source by http://www.most.gov.cn/tztg/201309/t20130917_109405.htm (in Chinese)

$\dagger$ Source by http://www.most.gov.cn/tztg/201402/t20140212_111801.htm (in Chinese)

* Press office of Ministry of Finance, 2016. "Notification of the Inspection of the Subsidies for the New Energy Vehicle Population (新能源气车推广应用补助资金专项检查的通报)”。

http://www.mof.gov.cn/zhengwuxinxi/bulinggonggao/tongzhitonggao/201609/t20160908_2413434.htm (in Chinese)

$\S$ People's Daily, 2016. “The MIIT is Stopping the New Energy Vehicle Subsidy Fraud” (in Chinese), http://energy.people.com.cn/n1/2016/0315/c71661-28199585.html

${ }^{* * *}$ Press office of Ministry of Finance, 2016. "Notification of the Inspection of the Subsidies for the New Energy Vehicle Population (新能源气车推广应用补助资金专项检查的通报)”。

http://www.mof.gov.cn/zhengwuxinxi/bulinggonggao/tongzhitonggao/201609/t20160908_2413434.htm (in Chinese)
} 
issued more than 190 diverse policies for popularizing PEVs. The major incentives by the local governments are categorized into five groups listed below.

- Prioritizing PEV registration: For example, the PEVs are eligible for exemption from the registration fees, and the PEV buyers are exempted for bidding on the license plate-lottery in Beijing, Shanghai, Hangzhou or other metropolitan cities. These first-tier cities have rigid regulations for vehicle license plate applications to control the fast growth of vehicles but PEVs are the exception. These regulations are critical to drive buyers to choose PEVs when considering car purchases.

- Exemption of traffic restrictions for PEVs: For example, in cities such as Beijing or Wuhan, road space rationing or traffic restrictions are enforced on workdays for congestion mitigation. To reduce the driving cost for the PEV drivers, PEVs are unconstrained and unaffected by the restrictions in these cities.

- Toll free for PEV in cities: For instance, Wuhan toll bridges/highways are toll-free to PEVs. The municipality of Shenzhen city allows first hour free parking for PEVs in municipal parking lots.

- Fiscal subsidy and tax exemption for the PEV ancillary facilities: The local governments encourage the charging equipment purchases and installations. For example, in the city of Shenzhen, the government directly subsidizes the PEV buyers $¥ 10,000$ CNY to $¥ 20,000$ CNY (\$1,541 to \$3,082 USD) for vehicle insurance, installation and purchase for home charging outlets. (2).

- Support for PEV manufacturers and other related industry producers. The auto manufacturers have priorities for obtaining concessional loans from the state-owned banks if the manufacturers invest directly in the PEV industry or upgrade the PEV production lines (2).

Due to the explosive growth of the PEV sales in 2015, PEV stocks have reached around 490,000 units. The PEV numbers proved the goal for PEV stocks to reach 500,000 by 2015, which was set by the Planning for the Development of the Energy-Saving and New Energy Automobile Industry (2012-2020) “ 节能与新能源汽车产业规划(2012-2020 年)”. Furthermore, because of the favorable policies, the number of the PEV manufacturers with annual production capacity of more than 10,000 PEVs has increased from two companies in 2014 to ten companies in 2015. Among them, four PEV manufacturers (BYD, Zotye, BAIC and Geely) are in the world's ten largest PEV manufacturers by sales in 2015.

Unlike LSEVs or unofficial EVs that are welcomed in the rural or suburb areas, most official EVs are sold in the big cities or other better developed regions. Fig. 26 shows the annual sales and PEV goals by local governments in major cities and provinces in China. In general, the PEV markets in the coastal developed areas or metropolitan cities developed much better compared with the PEV markets in inland areas or small cities. For example, Beijing, Shanghai, and Shenzhen (first-tier cities in China), and Jiangsu, Hebei, Zhejiang (Coastal provinces) have the largest PEV sales and their sales target ratios reached the highest in China. Fig. 27 shows the types of BEVs and PHEVs sold to private consumers for select cities.

Obviously, most of the PEVs sold to private consumers are in the first-tier cities and other province capitals.

Furthermore, the local economy has positive correlations with the PEV sales expectations revealed in Fig. 28. The GDP per capita is assumed to represent the economic development level, and the PEV sales goal accomplishment percentage is assumed to represent the PEV sales expectation. The average accomplished percentage in the provinces and direct-controlled municipalities (Tianjin, Beijing, and Shanghai) with GDP above the national GDP per capital is obviously higher than the accomplished percentage in the provinces and direct-controlled municipality (Chongqing) with GDP below the national GDP per capital. 
Considering the Inner Mongolia's geography and income levels that deeply reply on mineral products, Inner Mongolia is still regarded as an inland developing region.

In China, a larger PEV market tends to be in a region with a better economic development level, perhaps because the local governments have better financial capability to drive the promotion of the PEV market. For example, Zhejiang province, which is a coastal province in the Yangtze River delta economic zone, had the greatest PEV production in 2015 with four PEV OEMs in the 20 largest PEV OEMs by sales (see Fig. 15). One could assume that the municipal governments of these economic developed cities face more traffic problems and have to enforce restrictions on the number of vehicles which encourages people to purchase the EVs.

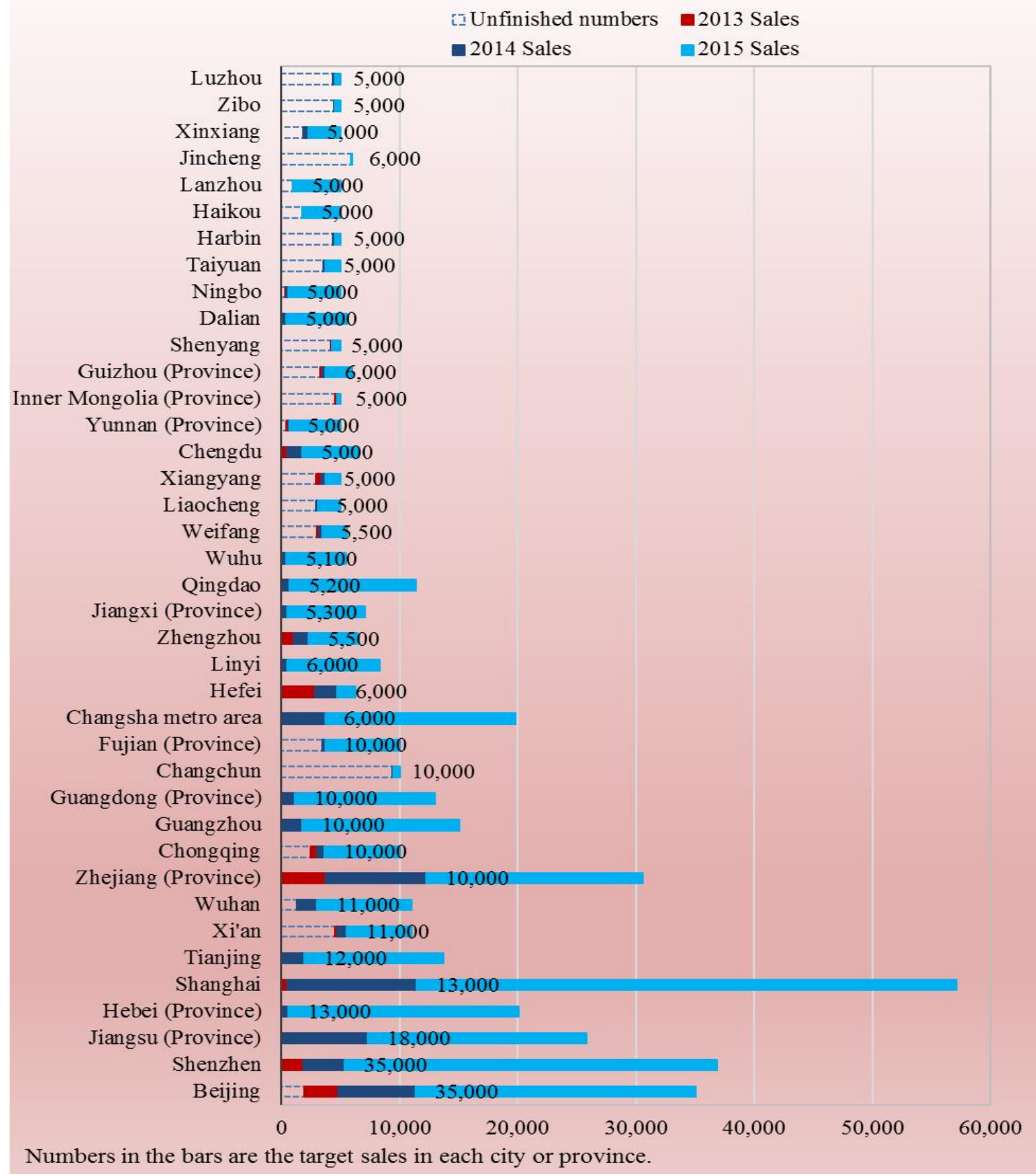

Fig. 26. PEV sales and government goals in major cities and provinces, 2013-2015 (2) 


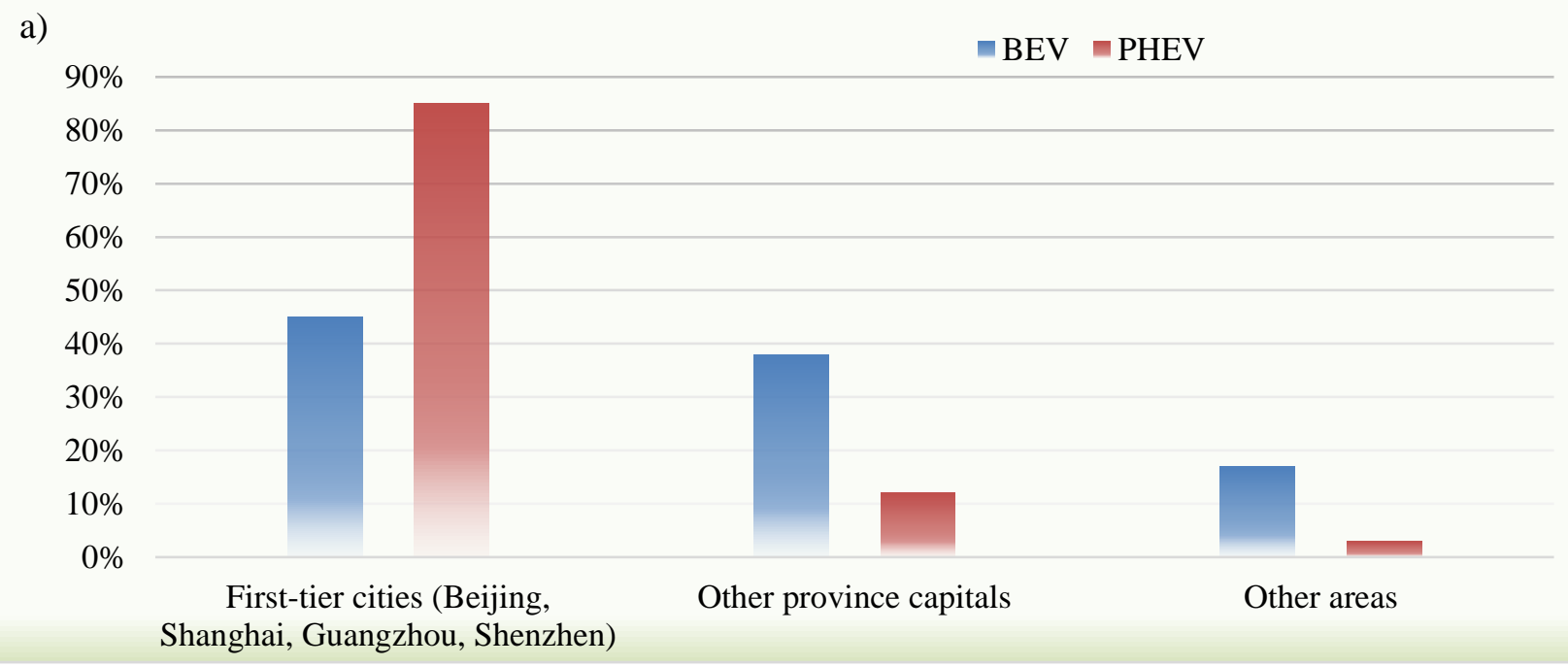

Fig. 27. City types distribution of sold out PEVs to private consumers in China (2);

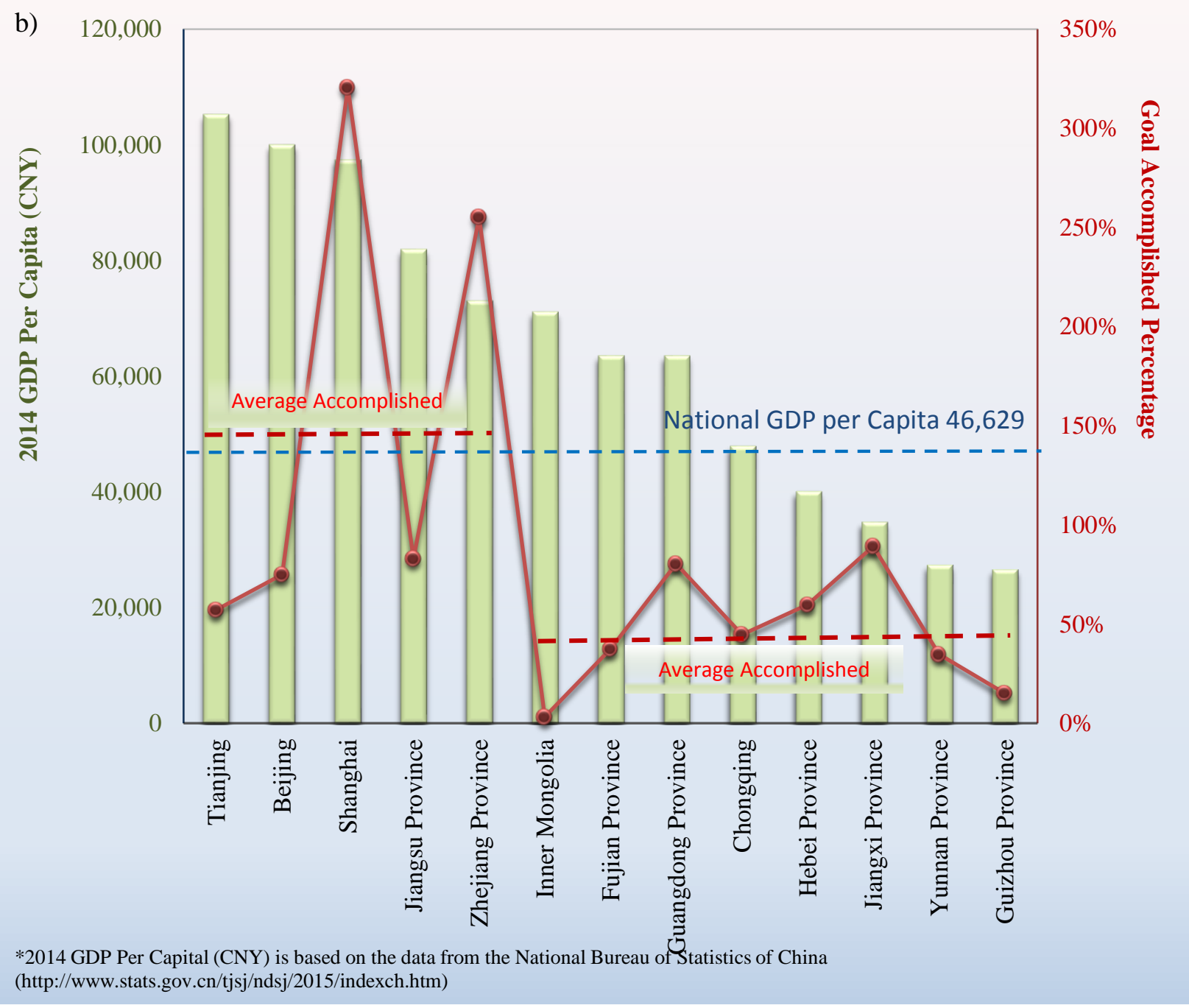

Fig. 28. Comparison with GDP per capita and the government PEV sales goal accomplished percentage 


\subsection{EVALUATION OF NEW POLICIES IN 2016}

Until the end of 2015, a series of incentives have been pushed forward for the sales growth of the PEV market and its infrastructure construction in China; however, excessive subsidies and subsidy fraud have been criticized by scholars ${ }^{*}$, and have drawn criticism by the government who has argued that the excessive monetary incentives without integrated regulations are harmful to the sustainable development of the PEV market in China ${ }^{\dagger}$. For 2016 and following years, the new incentives and policies in the PEV industry were instituted by the government to replace the old ones with some new industry standards to regulate the PEV technical specifications.

In March 2016, The MIIT issued a notification to enhance the management of the auto manufacturers and product qualifications ${ }^{\ddagger}$. This notification requires the automakers to guarantee the statistics of their PEV sales. Since then the government has started the investigation of the subsidy fraud and issued a NEV subsidy policy Notice on Financial Support Policies on the Promotion and Application of New Energy Vehicles (2016-2020) “关于 2016-2020 年新能源汽车推广应用财政支持政策的通知” in April 2015 . The central government policy calls for the subsidies for the domestic PEVs to gradually decline annually while the subsidies for the domestic FCEVs will increase from ¥ 180,000 CNY (\$27,739 USD) in 2015 to $¥ 200,000 \mathrm{CNY}$ (\$30,821 USD) in 2016 (Table 7). It is obvious that this new incentive improved the $\mathrm{PEV}$ technical requirements for subsidies. For instance, the minimum requirement of a BEV's driving range is increased from $80 \mathrm{~km}$ to $100 \mathrm{~km}$, and the maximum speed of a BEV is $100 \mathrm{~km} / \mathrm{h}(62 \mathrm{mph})$ instead of $80 \mathrm{~km} / \mathrm{h}(50 \mathrm{mph})$. In addition, more specific criteria are required for an electric bus to obtain subsidies in 2016 and the following years. The bus length $(\mathrm{m})$, vehicle electric range $(\mathrm{km})$ and specific energy consumption $(\mathrm{Wh} / \mathrm{km} \cdot \mathrm{kg})$ are comprehensively considered for subsidies ${ }^{* *}$.

Table 7. Central government subsidies for electrified passenger cars, 2016-2020 (Partial)

\begin{tabular}{|c|c|c|c|c|}
\hline Type & $\begin{array}{l}\text { Electric } \\
\text { Range }\end{array}$ & 2016 & 2017-2018 & $2019-2020$ \\
\hline $\begin{array}{l}\text { Plug-in Hybrid Electric Car } \\
\text { (Includes Extended Range EV) }\end{array}$ & $>50 \mathrm{Km}$ & $\begin{array}{l}Y 30,000 \\
(\$ 4,545)\end{array}$ & \multirow{4}{*}{$2016 \times 80 \%$} & \multirow{4}{*}{$2016 \times 40 \%$} \\
\hline \multirow{3}{*}{ Electric Car } & $100-150 \mathrm{Km}$ & $\begin{array}{l}Y 25,000 \\
(\$ 3,788)\end{array}$ & & \\
\hline & $150-250 \mathrm{Km}$ & $\begin{array}{l}Y 45,000 \\
(\$ 6,818)\end{array}$ & & \\
\hline & $>250 \mathrm{Km}$ & $\begin{array}{l}¥ 55,000 \\
(\$ 8,333)\end{array}$ & & \\
\hline \multicolumn{2}{|c|}{ Fuel Cell Electric Car } & $\begin{array}{l}¥ 200,000 \\
(\$ 30,303)\end{array}$ & & \\
\hline
\end{tabular}

\footnotetext{
*Yi Zhou. 12365 Auto. 2016. “More Than Half of EV Subsidies are by China (中国电动车补贴占全球一半)”. http://www.12365auto.com/news/20160125/215107.shtml (in Chinese) (visited in September 2016)

$\dagger$ Source by http://jijs.mof.gov.cn/zhengwuxinxi/lingdaojianghua/201601/t20160123_1656922.html (in Chinese)

$\$$ Source by http://www.miit.gov.cn/n1146285/n1146352/n3054355/n3057585/n3057592/c4662552/content.html (in Chinese)

$\S$ Source by http://www.miit.gov.cn/n1146290/n4388791/c4214459/content.html (in Chinese)

${ }^{* * *}$ Dongshu Cui. Auto Review 2016. "Changes of the Subsidy Policy for New Energy Vehicles and Opportunities for OEMs (新 能源汽车补贴变化与企业机遇)”. http://www.caam.org.cn/lundaotang/20150526/1405159588.html (in Chinese) (visited in September 2016)
} 
Along with the new specification requirements for PEV subsidies, the new Catalogue of Recommended Models for the New Energy Automobile Popularization and Application “新能源汽车推广应用工程推荐 车型目录” was released by the MIIT to replace the old one in February 2016, which requests all PEV manufacturers who want to obtain government subsidies to re-submit their applications for their product model. The New Subsidy Catalogue will be periodically updated to include the newly qualified PEV models. The stiffer standards help the MIIT to re-examine the PEV specifications and obsolete the unqualified products.

In the charging infrastructure market, a series of new industry standards for EV charging facilities were was released on January 1, 2016. The new standards will increase the safety and compatibility for diverse electric vehicles and charging outlets*. According to the Notification of Energy Guiding Suggestions in 2016 “2016 年能源工作指导意见的通知” ${ }^{\dagger}$ by the National Energy Administration (NEA) of China, more than 2,000 EV charging stations, 100,000 decentralized public charging outlets, and 860,000 private charging outlets are planned to be constructed in 2016.

Per the Planning for the Development of the Energy-Saving and New Energy Automobile Industry (20122020) “节能与新能源汽车产业规划(2012-2020 年)”, the Chinese government has reached their goal for accumulated sales and production of PEVs which were around 500,000 units by 2015. The Planning also expects the annual production of the PEVs to be two million units, and the accumulated sales to be more than five million units by 2020. The CAFC target for the new passenger vehicles is expected to be $5.0 \mathrm{~L} / 100 \mathrm{~km}, \mathrm{CAFC}$ for the new energy-saving passenger vehicles is expected to be $4.5 \mathrm{~L} / 100 \mathrm{~km}$ by 2020. Right now, The Fourth Stage of the Fuel Consumption Limits for Passenger Cars (GB 195782014) and the Fuel Consumption Evaluation Methods and Targets for Passenger Cars (GB 27999-2014) was released on January 1st, 2016, and requires the CAFC to be $6.7 \mathrm{~L} / 100 \mathrm{~km}$ for new passenger vehicles (2).

Fig. 29 shows the passenger vehicle CAFC targets in 2010-2025. Because of the differences in the test procedures and driving cycles for Chinese CAFC and U.S. CAFE. A transfer coefficient (0.86) is applied when comparing the Chinese CAFC and U.S. CAFE and is shown in Eq. [1] (12).

$$
\frac{3.785(\mathrm{~L} / \text { Gallon }) \times 62.137(\text { Mile } / 100 \mathrm{~km})}{C A F E_{M P G} \times 0.86}=C A F C_{\mathrm{L} /(100 \mathrm{~km})}
$$

In September 2016, the government published the draft regulation for CAFC credits and NEV credits. Similar to the CAFE and ZEV regulations in the U.S., this regulation (CAFC credits and NEV credits (2016-2020)) will change the government subsidies supervision to the auto firms, which shifts the pressures of PEV market development from the government to the automakers in China. The rules are impartial to both domestically produced and imported vehicles. Although the regulation bylaws such as energy transfer (the gasoline equivalent consumption), and the credit exchange prices are not clear yet, the new regulations will relieve the burdens on the government and keep the sustainable development of the PEV market.

\footnotetext{
* Source by http://www.nea.gov.cn/2016-01/05/c 134978578.htm (in Chinese)

$\dagger$ Source by http://zfxxgk.nea.gov.cn/auto82/201604/t20160401_2219.htm (in Chinese)
} 


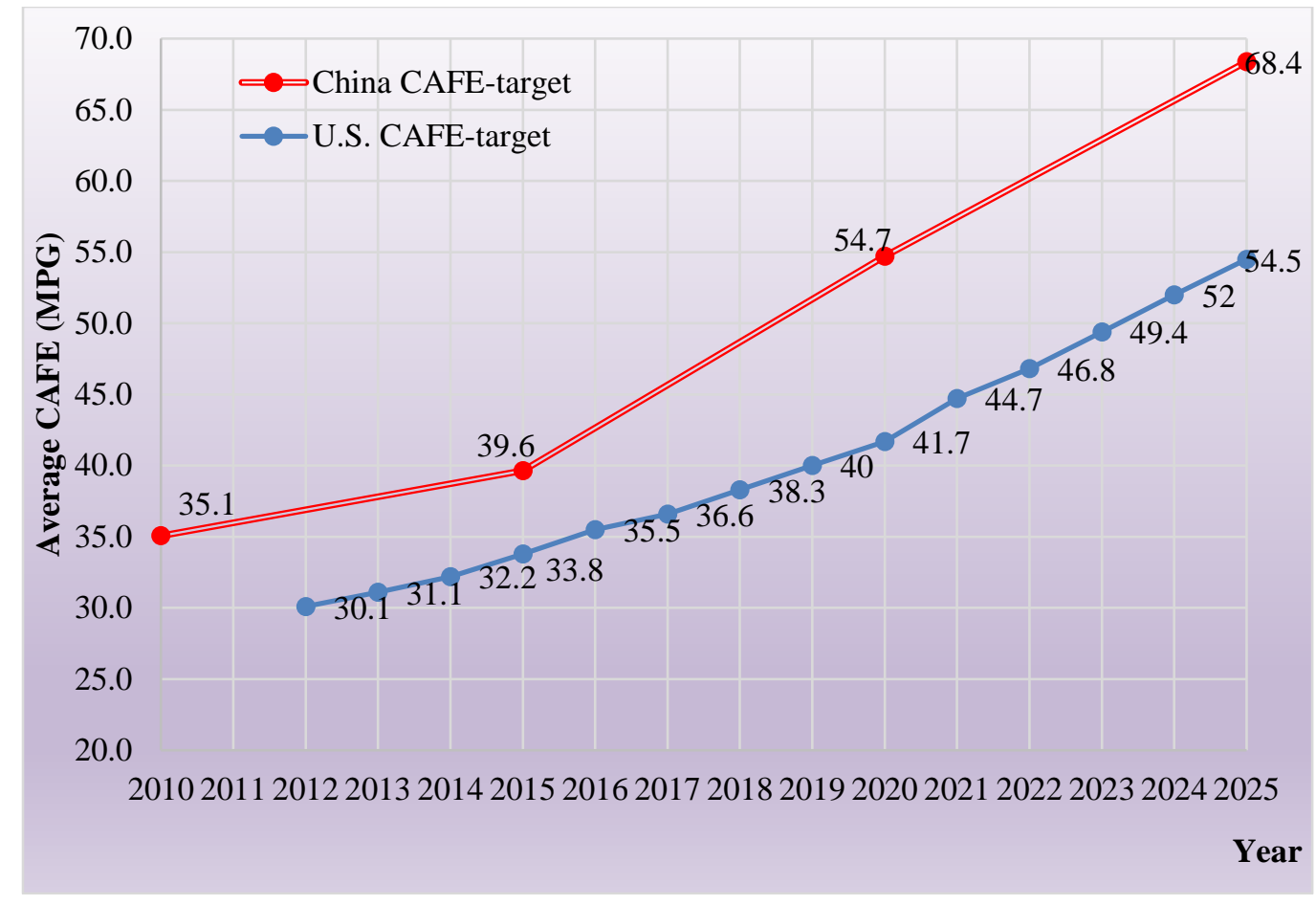

Fig. 29. CAFE targets (MPG) for passenger vehicles, 2010-2025 $(2,13)$

As more capitals and new players enter the PEV industry, and some problems (e.g., excessive low-end PEV products, PEV subsidy frauds) have been exposed in the nascent growth phase, the government is more guarded about the PEV industry expansion. In October 2016, China's Energy-saving and New Energy Vehicle Technology Roadmap “节能和新能源汽车技术路线图” was published, which explicitly presents the targets of the PEV technologies in details by the government. In 2016, the MIIT published the Rules on the Production Admission Administration of New Energy Automobiles “新能源汽车生产企 业及产品准入管理规定(修订征求意见稿)” (hereinafter referred to as the 2016 Rules), which requires the new entrants to meet more stricter criteria (e.g., fixed investment in the R\&D, assemble lines, and aftermarket maintenance). It is said the numbers of the new players, especially the entrants who have no experience in vehicle manufacturing, will probably be limited by the government which proactively adjusts the investment structure to avoid excess capacity and resource waste in low-end PEV products. Because of the limitations, some new PEV firms choose to cooperate with automakers who already have PEV manufacturing qualification to design and produce the PEVs together. For example, NextEV signed agreement with JAC who has PEV manufacturing qualification and will assemble and sell the PEVs for NextEV. It is expected that the automakers with low-end PEVs will be in a hard time if they fail to upgrade the quality and technology of their products, which requires vast investments or supports by the government incentives. 


\section{CHINA PLUG-IN ELECTRIC VEHICLE TECHNOLOGIES}

\subsection{EV BATTERIES}

An EV battery is used to power the propulsion of PEVs. The manufacturing cost of the battery in an EV can be at least $25 \%$ of the total cost, which has been the major bottleneck in commercializing the PEVs widely (14). Per the National Key R\&D on the New Energy Vehicles Specific Implementation Plan “国家 重点研发计划新能源汽车重点专项实施方案” issued by the Ministry of Science and Technology in February 2015, the average specific energy density of an EV battery should be $200 \mathrm{Wh} / \mathrm{kg}$ by the end of 2015 and this target should increase to $300 \mathrm{Wh} / \mathrm{kg}$ by 2020 . Table 8 shows the expectations of the average specific energy density and price of an EV battery in some major countries. According to CATARC report, China has built an integrated battery product line with the largest production capacity and market demands globally (2), which economies of scales would be an essential factor of cutting the battery cost down to meet the target.

Table 8. Specific energy density goals of EV batteries in major countries (2)

\begin{tabular}{|c|c|c|c|}
\hline & 2015 & 2020 & 2030 \\
\hline China & $200 \mathrm{Wh} / \mathrm{kg}$ & $300 \mathrm{Wh} / \mathrm{kg}$ & $\mathrm{n} / \mathrm{a}$ \\
\hline Japan & $\mathrm{n} / \mathrm{a}$ & $250 \mathrm{Wh} / \mathrm{kg}$ & $500 \mathrm{Wh} / \mathrm{kg}$ \\
\hline S. Korea & $\mathrm{n} / \mathrm{a}$ & $250 \mathrm{Wh} / \mathrm{kg}$ & $\mathrm{n} / \mathrm{a}$ \\
\hline U.S. & $\mathrm{n} / \mathrm{a}$ & $250 \mathrm{Wh} / \mathrm{kg}$ & $\mathrm{n} / \mathrm{a}$ \\
\hline Germany & $130 \mathrm{Wh} / \mathrm{kg}$ & $\mathrm{n} / \mathrm{a}$ & $\mathrm{n} / \mathrm{a}$ \\
\hline
\end{tabular}

Worldwide, China's battery suppliers grow fast through facing great challenges from the battery manufacturers in South Korea and Japan who are taking the lead positions in the battery industry. It is said that Panasonic, LG and Samsung SDI will make up about $80 \%$ of the EV battery market in the next five years". However, relying on the large economies of scales and vast market demands in the Chinese market, five Chinese EV battery suppliers leaped into the ranking of the ten largest battery suppliers by global sales in 2015 (See Fig. 30). Extravagant investment drives the progress of the Chinese EV battery industry. Reported by Deloitte, ¥35 billion CNY ( $\$ 5.39$ billion USD) was invested into the PEV industry between January 2014 to June 2015, and $¥ 15.5$ billion CNY (\$2.39 billion USD) entered to the EV battery industry which makes up around $45 \%$ of the total capital investment in the PEV industry ${ }^{\dagger}$, shown in Fig. 31. The production of EV batteries grew along with the PEVs sales in China as 2015 battery production grew to $470 \%$ over 2014 production (2).

\footnotetext{
* Mike Ramsey. The Wall Street Journal, 2015. "Auto Industry's Ranks of Electric-Car Battery Suppliers Narrow" http://www.wsj.com/articles/auto-industrys-ranks-of-electric-car-battery-suppliers-narrow-1440021009.

† Source by Deloitte, 2015 “2015 Clean Energy Industry Report: Towards to A New Mainstream” (in Chinese). Beijing China.
} 


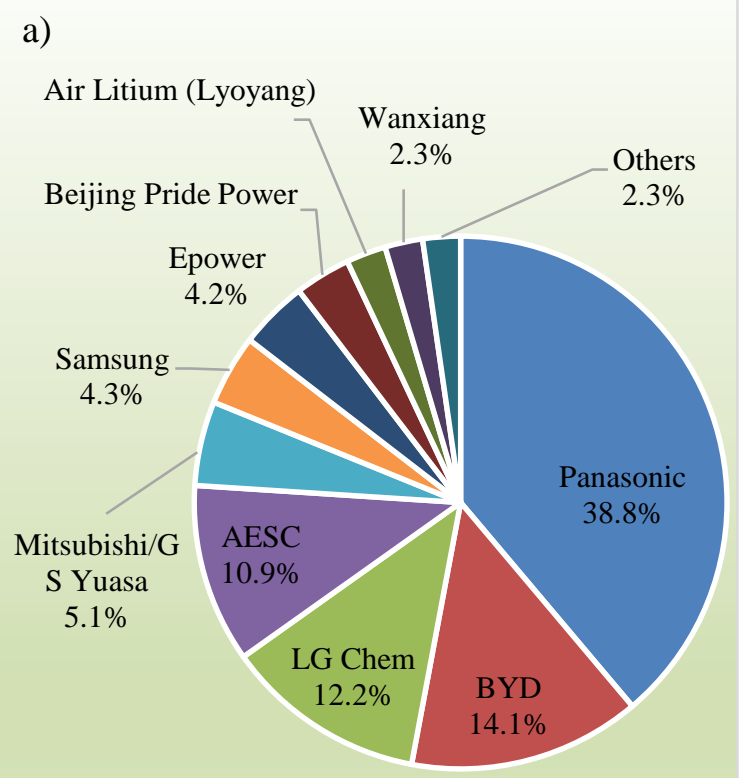

2015 Market Share

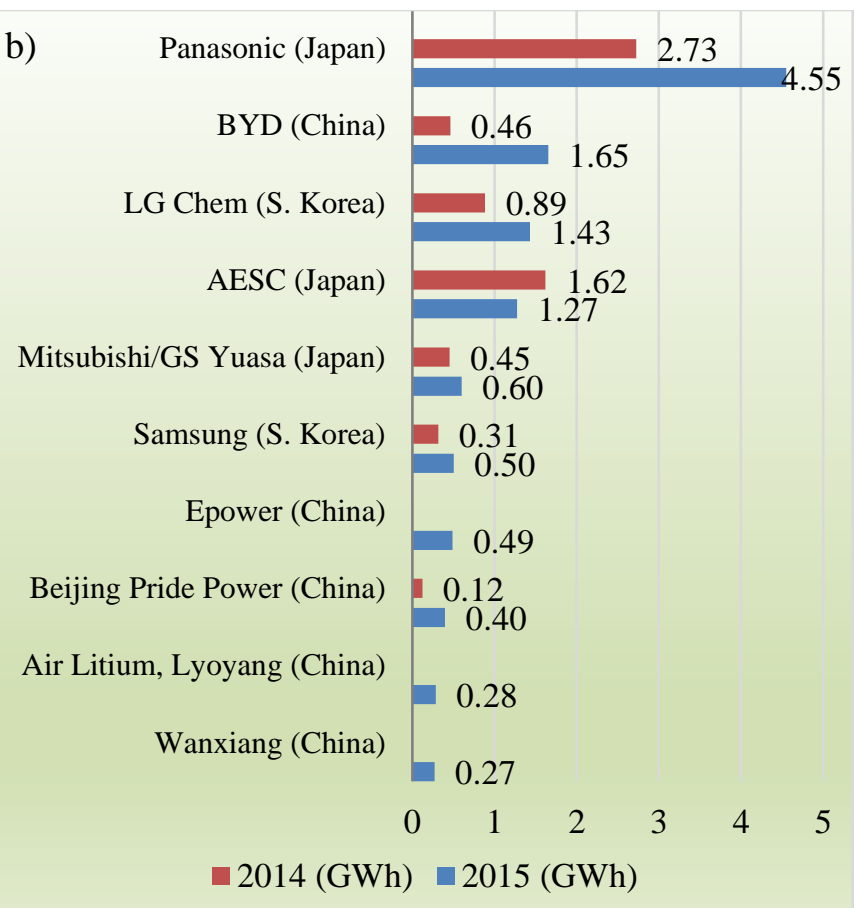

Fig. 30. Largest global EV battery manufacturers by sales and market share, 2014-2015*
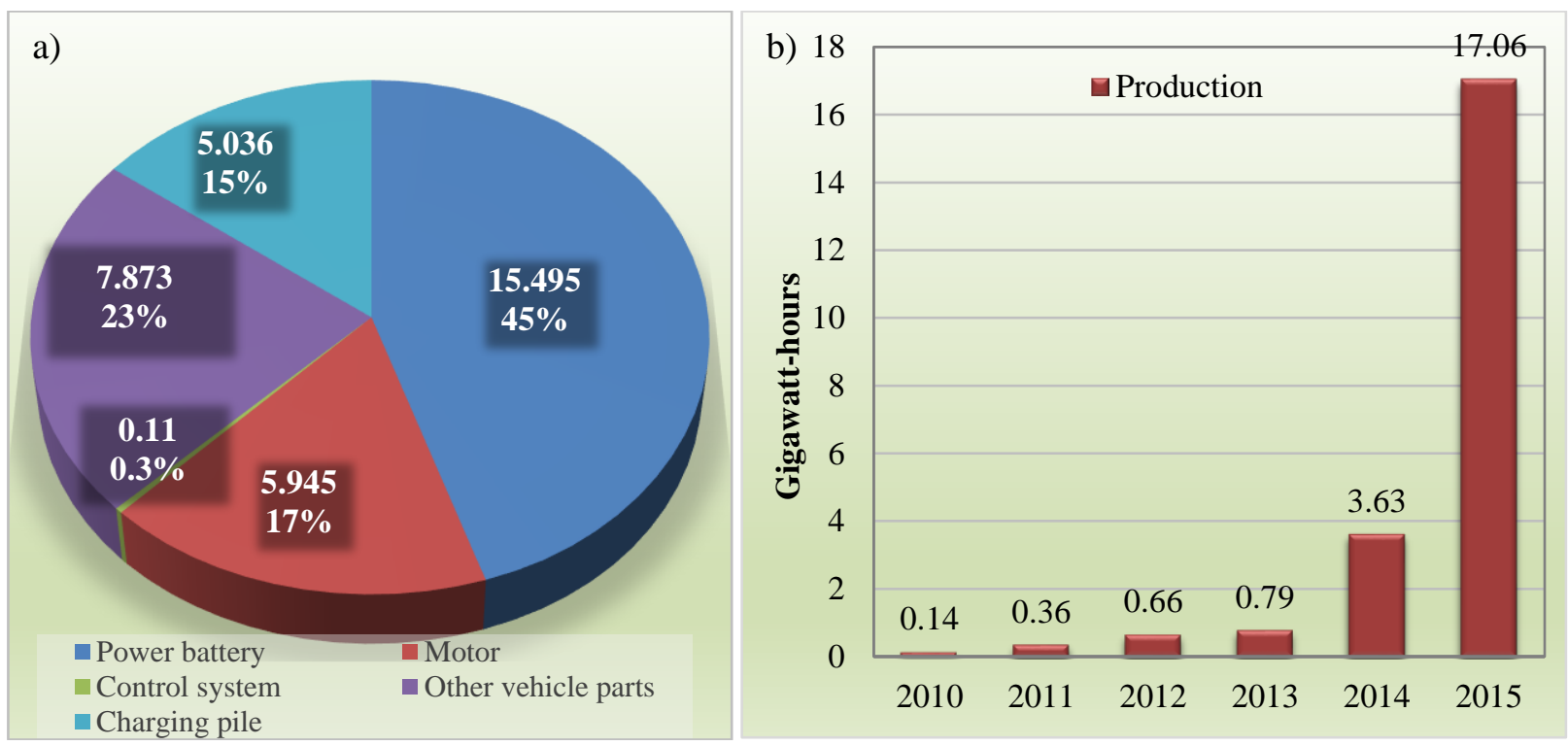

Fig. 31. a) China's PEV industry investment (billion CNY), Jan 2014-Jun 2015'; b) China's EV battery (GWh) production, 2010-2015 (2)

\footnotetext{
* James Ayre. EV Obsession, 2016. "Top EV Battery Producers (2015 vs 2014 Top 10 List)". http://cleantechnica.com/2016/03/26/top-ev-battery-producers-2015-vs-2014-top-10-list/.

† Source by Deloitte, 2015 “2015 Clean Energy Industry Report: Towards to A New Mainstream” (in Chinese). Beijing China.
} 
Recognizing the lucrative EV battery market, multinational battery suppliers are entering the Chinese EV battery market. Foreign battery makers are directly investing and expanding their capacity in China. For example, LG Chem opened a mega EV battery plant in October 2015 specifically for PEVs for the SAIC Motor Group. * In October 2015, Samsung SDI started operating its EV battery plant in Xi'an, China and it has the capacity to produce EV batteries for over 40,000 PEVs annually aiming to achieve over $\$ 1$ billion USD in sales. ${ }^{\dagger}$ Panasonic has decided to invest \$412 million USD to build a new lithium-ion battery plant in China ${ }^{\ddagger}$. At the same time, some foreign brands, such as the A123 Systems and Boston Power, have been purchased by the Chinese capitals to supply batteries for the Chinese OEMs. In spite of the phenomenal expansions in battery production capacity and market demands, Fig. 32 shows that the total number of the EV battery suppliers in China had increased to 200 units by 2015 (2), which diminishes the market concentration that had existed since 2012.

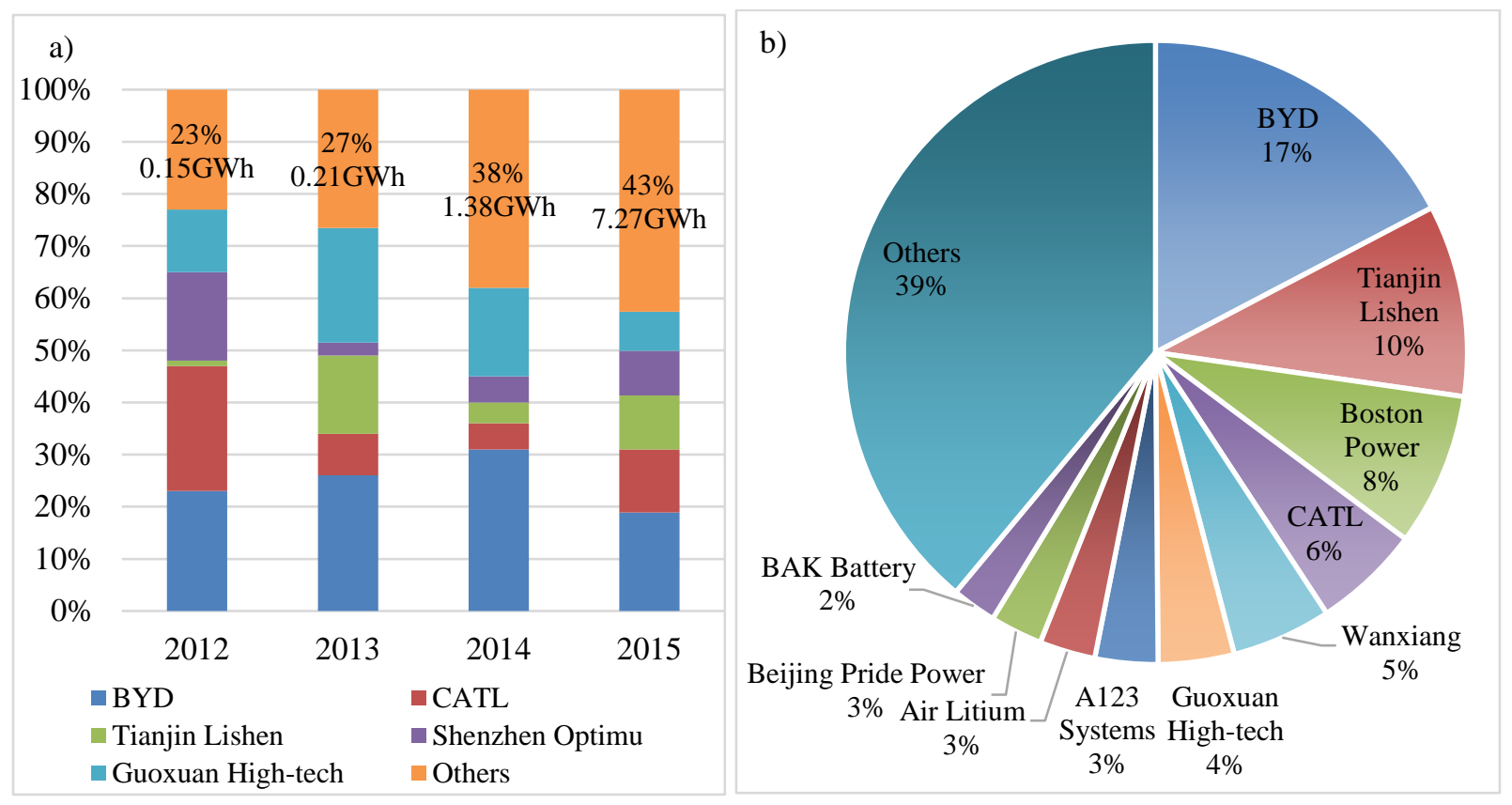

Fig. 32. a) Chinese EV battery suppliers by ranked by production (GWh) in China, 2012-2015 (2); b) EV battery suppliers market shares by number of PEVs installed in China, 2015

The lithium-ion battery, which was first commercialized by the Japanese in the 1990s, has been the major type of battery powering the electric mobility. With the advantages of high charge/discharge performance, larger energy capability, and acceptable lifetime, the lithium-ion battery has been adopted into cars, motorcycles, heavy vehicles and off-road equipment. Globally, most lithium-ion batteries are probably made in China and its neighbors countries of Japan and South Korea. Currently in China, in spite of the fact that the lead acid battery is toxic to the environment and human beings, the lead acid battery is still being used by some LSEV makers as the power resource because of its much lower cost. To help make

\footnotetext{
*Yoo-chul Kim. The Korea Times, 2015. "LG Chem Opens Mega Battery Plant in China”, http://www.koreatimes.co.kr/www/news/tech/2015/10/133 189601.html

${ }_{\dagger}$ Samsumg SDI, 2015. "New Silk Road for Electric Cars Erected in Xi'an" http://www.samsungsdi.com/sdinews/674.html?pageIndex $=1 \&$ id $x=674 \&$ searchCondition $=0 \&$ searchKeyword $=$

$\$$ Panasonic News Bureau, 2016. "Joint Venture Company Established to Manufacture Automotive Batteries in Dalian, China”, http://news.panasonic.com/global/press/data/2016/02/en160205-2/en160205-2.html

§ Xiaojie Yang. Gasgoo 2016. “2016 Largest EV Batteries by Vehicles Installed (2015年动力电池十强企业榜单)”.

http://auto.gasgoo.com/News/2016/01/2001270627660353489979.shtml (in Chinese)
} 
the lead acid batteries obsolete, PEVs with lead acid batteries are not eligible for the government subsidies in China.

To gain more market share, various types of lithium batteries (such as lithium-ion manganese oxide batteries, lithium ferro phosphate batteries, lithium nickel cobalt manganese batteries, or lithium nickel cobalt aluminum oxide batteries) are being used in NEV sales. The primary type of the lithium-ion battery produced by the domestic battery suppliers is the lithium ferro phosphate (LFP) battery and has been produced in large-scale in China with its low manufacturing cost and good safety records. The lithium nickel cobalt manganese (NCM) battery is another lithium battery type which is in high favor with the South Korean and Japanese battery makers. In general, the NCM batteries have larger energy density while the materials for NCM batteries have less high-temperature stability compared with the LFP batteries. The NCM materials decompose with violent reactions at around 200 Celsius degrees, although battery safety is also related to battery management system, manufacturing, and assembly.

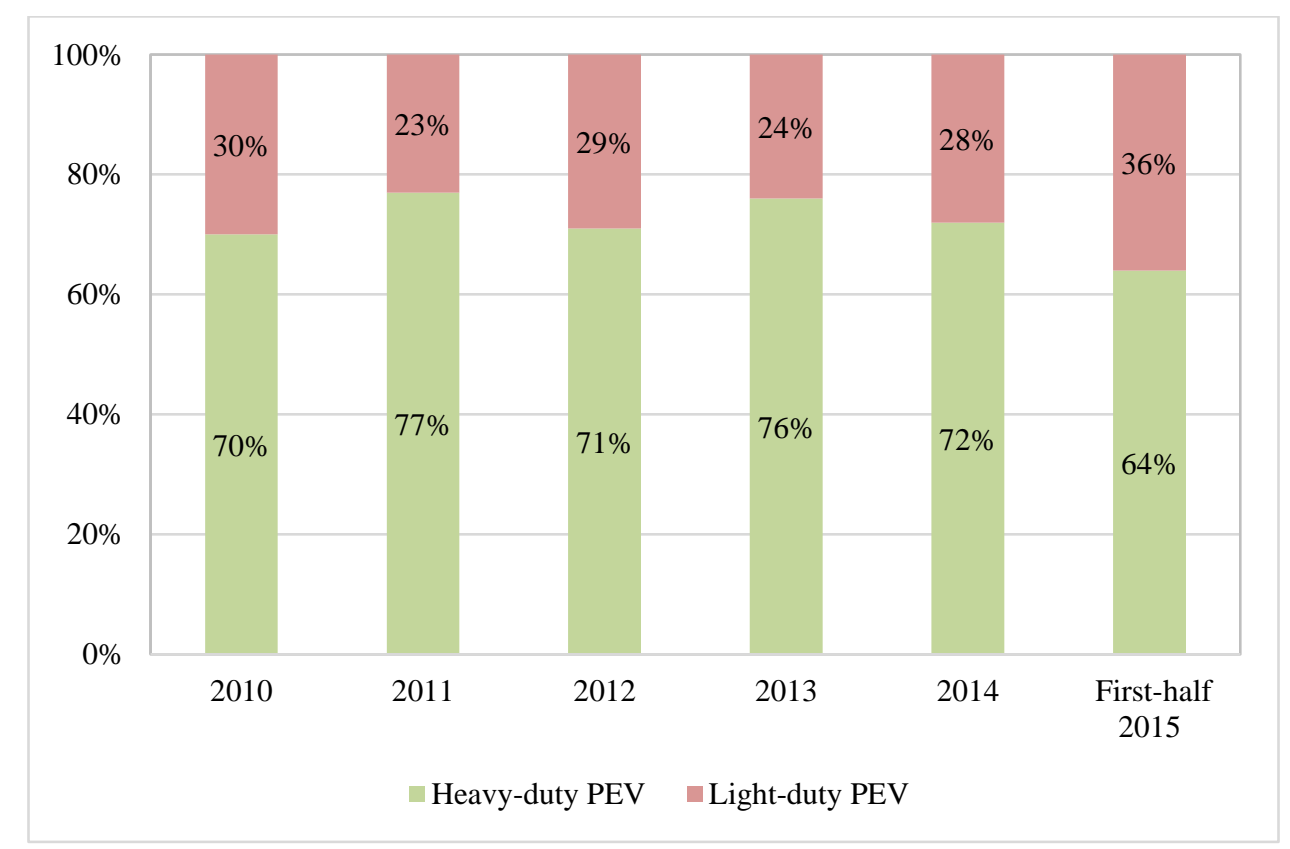

Fig. 33. Installation of EV batteries by type (GWh) in China's PEV market, 2010-2015*

Because of the large demands of the heavy-duty PEVs for batteries, the suppliers are fiercely wrestling for the market share of batteries for heavy-duty PEVs. In the Chinese EV battery market, the NCM batteries are predominately supplied to the light electric cars, while most of the LFP batteries are utilized for the commercial buses, which demands over $64 \%$ of the battery capacity sold (GWh) in the battery market and is shown in Fig. 33. Though electric bus sales are less than electric cars, the battery capacities per bus are much larger, which creates a larger demand for batteries. In January 2016, the MIIT announced that the government would suspend the subsidies for electric buses installed with NCM batteries until the safety assessment report for this battery type was released. The caution of the government was for safety concerns on a few electric buses with NCM batteries that had spontaneous fire issues in 2015. The government suspected that the NCM batteries might have higher risks to cause serious problems.

\footnotetext{
* Source by CICC China Lithium Battery Investment report, 2016. http://www.niuniuwang.cn/wpcontent/uploads/2016/01/\%E9\%94\%82\%E7\%94\%B5\%E6\%B1\%A0.pdf (in Chinese)
} 
Meanwhile, the NCM battery policy changes might have broad influences in the battery industry, which would depress the production anticipation by the battery suppliers who might have excess production capacity than the market demands. At the same time, this new announcement for NCM batteries was protested by the South Korean government who claimed that the new policy in NCM batteries would seriously affect the South Korean battery makers in China*. The South Korean government argued that the modified rules provide incentives to LFP batteries which the majority are sold by Chinese manufacturers, and are an apparent move to boost its local manufacturers and isolate their South Korean rivals who produce mostly NCM batteries.

\subsection{BATTERY CHARGING INFRASTRUCTURE}

\subsubsection{Comparison of Public EV Charging Outlets}

The development of the EV infrastructure facilities for PEVs in China has had good progress, although it is still in the preliminary phase. By December 2015, the ratio of non-home charging outlets ${ }^{\dagger}$ to PEVs reached 0.27 (2) which implies that 0.27 charging outlet is utilized per PEV out of home. The numbers of non-home charging outlets in China, U.S., and Japan are compared in Fig. 34. Fig. 34 and Fig. 35 only consider the public charging outlets. China and the U.S. had roughly the same numbers of PEVs on the road by 2015, while China did much better in the number of public charging facilities. China's also ratio of public fast-charging/total-charging outlets is the highest of the three countries. This might be due to China having the largest numbers of public PEV fleets and thus installed most public charging facilities for charging, while most PEVs in U.S. are owned by individuals who have private charging outlets at home.

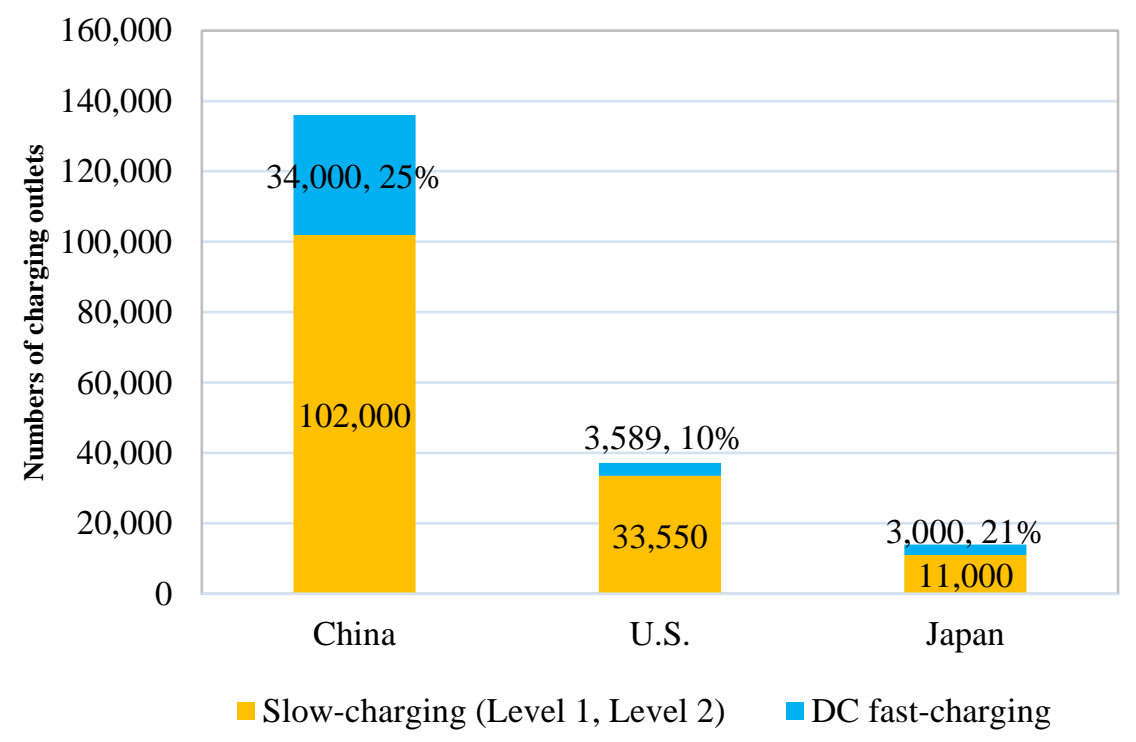

Fig. 34. Numbers of non-home charging outlets in China, U.S., and Japan $\$(2,7)$

\footnotetext{
* Sejong. Yonhap News, 2016. "S. Korea to protest China's electric battery subsidies", http://english.yonhapnews.co.kr/news/2016/02/23/0200000000AEN20160223007200320.html

$\uparrow$ Since the numbers of home charging outlets are hard to access, the statistics for charging facilities in this study exclude the charging outlets used for home only.

\$ The statistics of China is by CATARC by December 2015, the statistics of Japan is by CATARC by December 2014. The U.S. data access by April 13, 2016. The U.S. charging stations include Level 1, Level 2, DC fast, and Legacy chargers. The cumulative PEV number is 428,735 by March 31, 2016. (http://www.anl.gov/energy-systems/project/light-duty-electric-drivevehicles-monthly-sales-updates).
} 


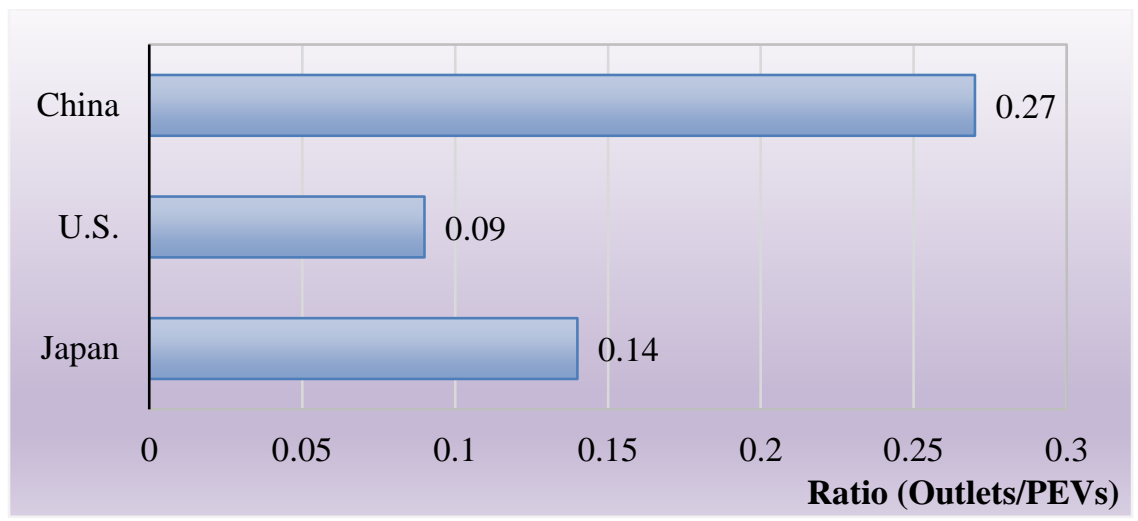

Fig. 35. Non-home charging ratio in China, the U.S., and Japan

\subsubsection{Distribution of EV Charging Outlets}

The distribution characteristics of the EV charging outlets are analyzed in this section. Chronologically comparing the installation speed of new charging outlets has lagged the growth of the EV numbers on road. The ratio of the charging outlet numbers to EV numbers constantly declined in the last 5 years as seen in Fig. 36. Fig. 37 summarizes the groups of the EV charging outlets in China by technical type, purpose, and location. Though the DC fast charging outlets cost more, they can greatly reduce the waiting time for fully charging, which might ultimately increase the consumers' willingness to purchase PEVs. The DC fast charging outlets comprise $25 \%$ of all outlets in China. Meanwhile, shown in Fig. 37 b), $31 \%$ of the charging outlets are for specific users which are public service departments such as the sanitation vehicles, public buses or taxis" and reflects that a certain amount of PEVs are procured by the government or public service departments ${ }^{\dagger}$. In addition, China has installed $900 \mathrm{EV}$ charging outlets in rest areas along the national highways, and most are DC fast charging outlets (2) that make it conducive for longdistance $\mathrm{EV}$ drivers to extend their electric driving ranges.

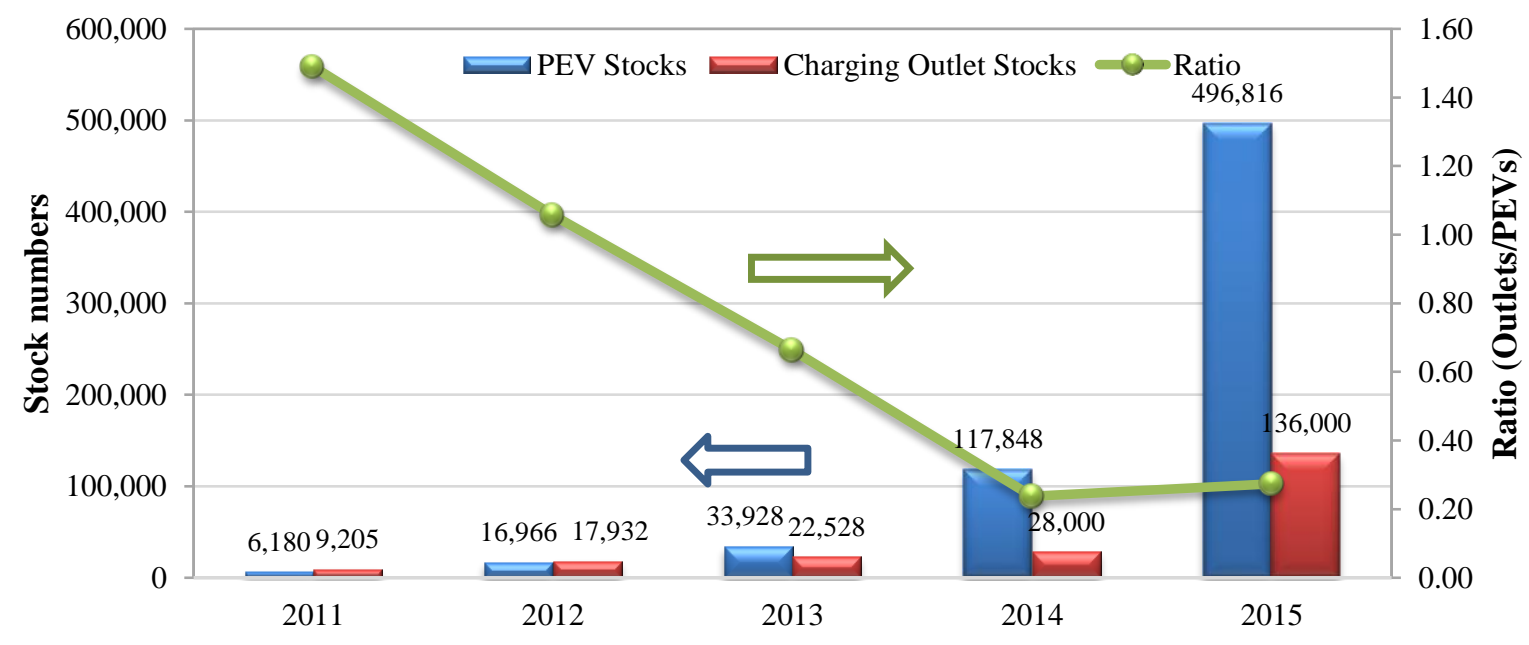

Fig. 36. Number of PEVs and charging outlets in China, 2011-2015 (2)

\footnotetext{
* Charging outlets for public users are for any PEV consumers; Outlets for private are the users through a business-to-business arrangement, such as for community neighbors, company employees, mall customers etc. Outlets for specific users target the PEV consumers for freight transport, engineering emergency rescue, sanitation, postal services, etc.

$\dagger$ Jie Ma. Bloomberg, 2016. "China Electric Car Boom Driven by State Buying, Bernstein Says", http://www.bloomberg.com/news/articles/2016-03-01/china-electric-car-boom-driven-by-state-buying-bernstein-says
} 


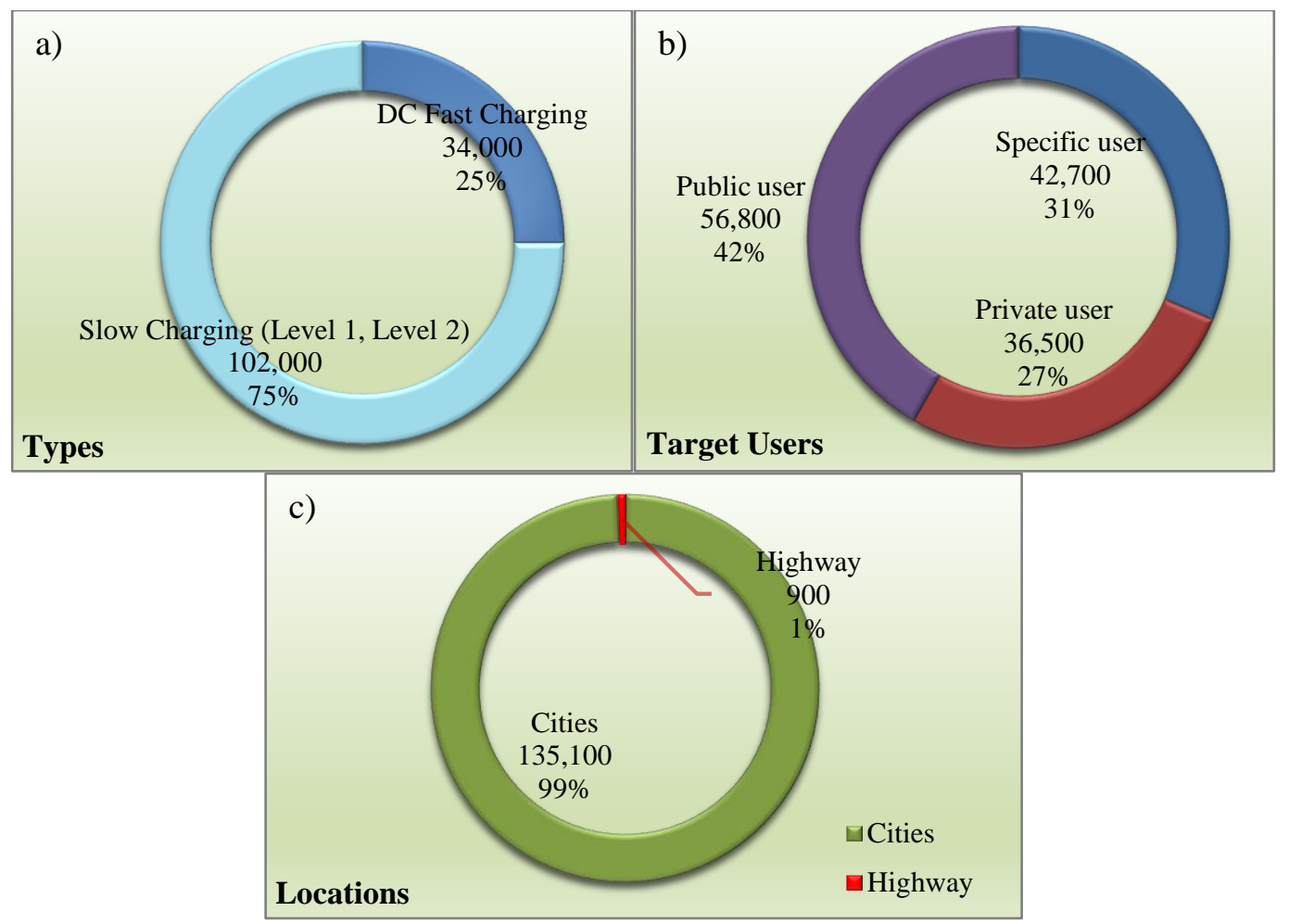

Fig. 37. Distribution characteristics of charging outlets in China, 2015

Most of the charging outlets are located in the megacities in China as seen in by Fig. 38. The municipalities of these cities have fiscal capacity to propel the EV infrastructure construction. Meanwhile, the restriction of conventional vehicles in these cities encourage people to purchase PEVs, which also lead to the demands of the charging outlet installations.

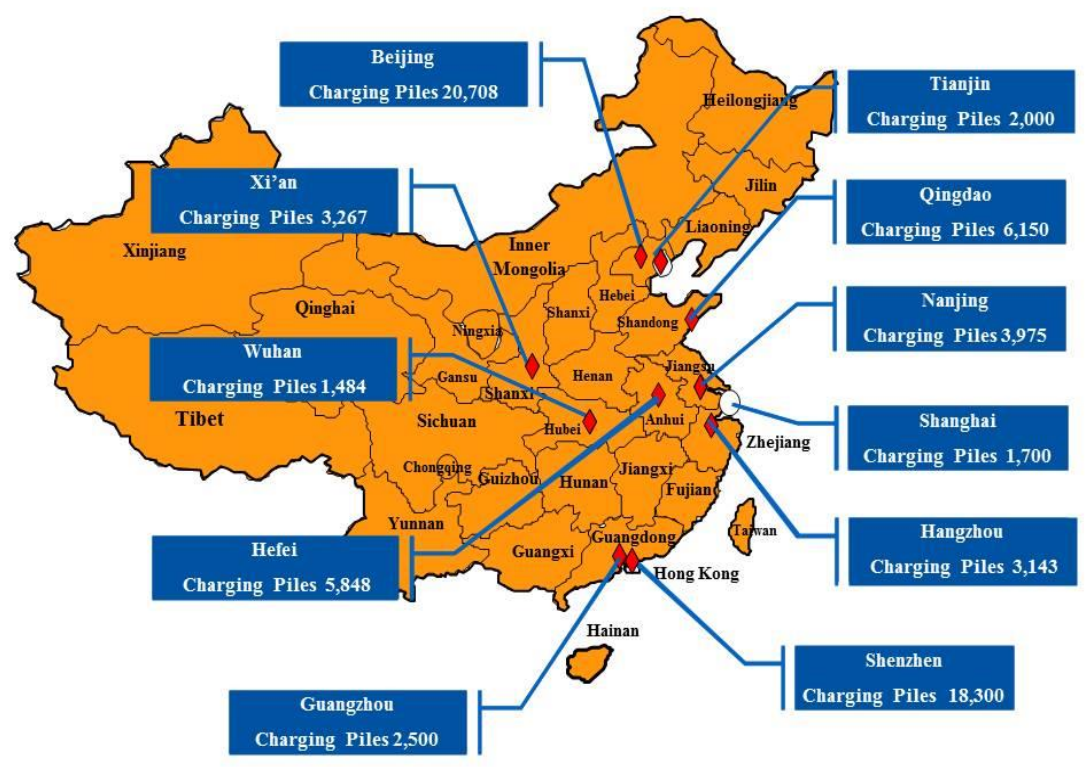

Fig. 38. Number of EV charging outlets in major cities in China, 2015 
As the most important participant in the development of charging infrastructure in China, the State Grid Corporation of China (SGCC) greatly influences the expansion speed of the charging stations/outlets in China. Per the SGCC annual report, the SGCC had built 1,537 battery charging/swap stations and 29,600 charging outlets by December 2015. Some charging stations built by the SGCC are located on the highways between major cities providing charging service for about 11,000 km highway network and greatly extends the traveling distance of PEVs. ${ }^{*}$ To improve the installation speed of new EV charging stations, the Chinese government has been reforming the state electric power sector by breaking electricity distribution monopolies over sales and gradually opening the electric power market to the public. These incentives encourage the capitals to build their own electric power charging grids, and to sell the power directly to consumers through the charging outlets for cars, housing or heating $(15,16)$.

Due to the growth of the charging infrastructure market and the encouragement of the incentives, numbers of the competitors in the charging outlets market in China have increased to more than 10 units, such as SGCC, Potevio New Energy, Tesla, Teld, Star Charge, Huashang Sanyou, Wanma, Tellus Power. Tesla is the only vehicle manufacturer that provides both electric cars and charging outlets. To promote its car sales, Tesla has installed 1,920 charging outlets for its consumers in China as of December, 2015. The Star Charge is an internet platform for small charging outlets providers. By providing the usage information of charging outlets through the smart phone application, EV charging availability is shared between PEV drivers and charging outlets providers, which assists the PEV driver in finding a charging outlet nearby.

In December 2015, the government issued five new vehicle charging national standards which was effective on January 1, 2016. These new standards were established by many charging outlet providers and PEV manufacturers including BAW, SAIC, Tesla, and others. ${ }^{\dagger}$ The standards have regulated the charging device manufacturing process, specifications, battery management system/motor communication protocols which will improve the quality and unify the specifications of charging outlets and EV charging devices. More importantly, the charging standards will bolster consumer confidence and assist PEV drivers with better charging accessibility.

\subsubsection{Planning}

More charging facilities will be built per the Chinese government plans. In October 2015, the government issued the Guidelines for the Development of Electric Vehicle Charging Infrastructure (2015-2020) “电 动汽车充电基础设施发展指南(2015-2020 年)” (hereinafter referred to as the Guidelines), which ambitiously proposes that more than 120,000 charging stations, and more than 4.8 million charging outlets be built in China by 2020 .

Fig. 39 shows the categories of these new charging stations and charging outlets per their target users. It is noticeable that the government Guidelines aims for the construction of new battery charging/swap stations to mainly occur at the public transit/service system or the highway rest area service system, while it targets the construction of new scattered charging outlets for the individual users who are more sensitive to the charging cost and accessibility. Shown in Fig. 39 a), the plan for charging stations installed for intercity highway service with 800 units will comprise only $6.7 \%$ of the total battery charging/ swap stations by 2020. More than $90 \%$ of the charging stations will be built in the cities. The government will invest more into charging stations for the electrified cars/buses in city's public service

\footnotetext{
*SGCC, 2016. "SGCC 2015 Social Responsibility Report" (in Chinese), http://www.sgcc.com.cn/csr/images/reports/2016/02/22/C0F6696460C59686CFA54B9C11EFCB06.pdf

† Yangong Hu. People’s Daily, 2016. "Review China Charging Market’s Development from Tesla trying to adopt China's Charging Standards" (in Chinese), http://auto.people.com.cn/n1/2016/0121/c1005-28071764.html

\$ Rose Yu. The Wall Street Journal, 2015. "Tesla Pledges to Meet China Charging Standards", http://www.wsj.com/articles/teslato-modify-cars-to-meet-china-charging-standards-1431412891
} 
especially. Thus, the development of the PEVs in cities will reply on the improvement of the public transport or service.

The government encourages scattered charging outlets at home/workplace construction, which will comprise $89.6 \%$ of the total charging outlets by 2020, shown in Fig. 39 b). Per the Guidelines, the individual-owned PEVs are regarded as the commuting tool between home and workplace rather than the transportation for long-distance travel, and the fiscal subsidies for charging outlets installation are encouraged to be used for charging outlets at home or workplace. Meanwhile, the Chinese government considers the well-developed public transit as the primary transportation for other trip purposes, and thus constantly invests in the charging facilities for the PEVs used for public services. The government believes that the popularizing of the PEVs, particularly the promotions of the PEV public transit, will reduce GHG and save energy costs, and mitigate the traffic congestion in the metropolitan cities.

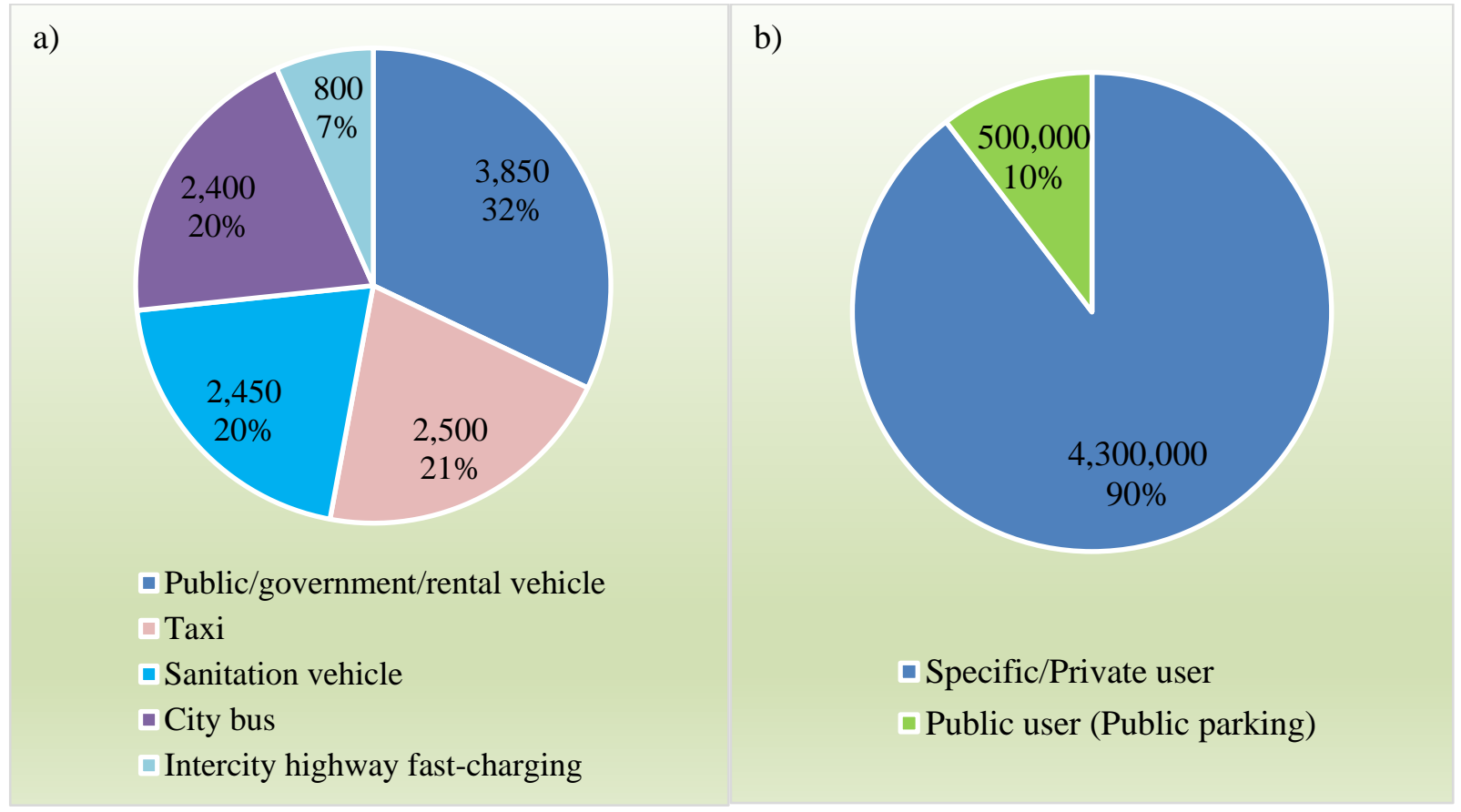

Fig. 39. Plans for constructing a) charging stations and b) charging outlets in China by 2020 (2)

The charging outlet market will be continually prosperous in the near future. Per the Planning for the Development of the Energy-Saving and New Energy Automobile Industry (2012-2020) “节能与新能源汽 车产业规划(2012-2020 年)” * issued by the State Council, it is expected that the ratio of PEVs/charging outlets will be increase to 0.96 by 2020 , when the numbers of PEVs on road will reach 5 million units.

\subsection{OTHER ELECTRIFIED VEHICLE TECHNOLOGIES}

\subsubsection{Fuel Cell Electric Vehicle}

With low heat values (LHV) of $120.9 \mathrm{~kJ} / \mathrm{g}$, hydrogen, which is the most common substance in the universe, has the highest specific energy of any known fuels (17). FCEV is considered a zero-emission vehicle (ZEV) that is attractive to researchers and manufacturers. Japan, U.S., Europe, and South Korea have made plans to develop the FCEV for the future AFV market. By May 2016, 1,149 FCEVs have been

\footnotetext{
* Source by http://www.ycdpc.gov.cn/ywgl/gyfz/201204/W020120508580846293516.pdf (in Chinese)
} 
sold in the U.S. ${ }^{*}$ Specifically, Toyota Mirai which was released in 2015 is the best-selling FCEV in the world so far. The driving range of this FCEV was reported to be 312 miles (2016 Mirai EPA estimated range). ${ }^{\dagger}$ The price of the Mirai is not extraordinarily high now. The MSRP for a Mirai is $\$ 57,500$ USD or $\$ 499$ USD to lease in the U.S., which reflects a lower price than it was years ago. With combined state and federal incentives of $\$ 13,000$ USD available to many customers, the actual purchase price could potentially fall to below $\$ 45,000$ USD.

China's central government has decided to improve the FCEV technologies. A national plan - Made in China 2025 (中国制造 2025) ${ }^{\S}$ which was released by the State Council in 2015 emphasized the development of the Chinese FCEV technologies. Moreover, the FCEV technologies will be invested in more than before, based on the China Thirteen Five Years Plan (Year 2016 - 2020). However, unlike the ambitions in the development for PEVs, the Chinese government only expects Chinese FCEVs will be small-scale demonstration running in some cities by 2025 (According to the China's Energy-saving and New Energy Vehicle Technology Roadmap “节能和新能源汽车技术路线图” released in October 2016, 50,000 units will be running on road in China by 2025). Comparing the prosperity of the PEV market, the Chinese government might face more difficulties to propel the development of the FCEV market.

Currently, most Chinese FCEV projects are still in the laboratories of a few universities or being bench tested at the automotive manufacturers (ten FCEVs produced by SAIC Motor were demonstrated in Shanghai in 2015). The overall research in the fuel cell powertrain lags behind the other major countries such as Japan, and the U.S. (10). Compared to Mirai which has a fuel cell stack with average power density $3.1 \mathrm{Kw} / \mathrm{L}$, the average power density of the fuel cell stack in the Chinese demonstration vehicles is around $1 \mathrm{~kW} / \mathrm{L}(10,18)$. The normal hydrogen operating pressure in the storage of Mirai achieved 70 $\mathrm{MPa}$ with the use of carbon fiber-resin composite materials $(10,19)$, while the pressure of the on-board hydrogen storage in Chinese demonstration vehicles is $35 \mathrm{MPa}$. At the same time, because of few FCEVs on the road in China, only 2 hydrogen refueling stations were experimentally operating by 2015; however, 23 hydrogen refueling stations are operating in the U.S. and more hydrogen stations are in Japan $(7,10)$.

\subsubsection{Battery Swap BEVs/Stations}

The battery swap EV/station is another trial to promote the popularization of EVs in China. Instead of charging the BEVs at electrical chargers, batteries replacements in the battery swap stations is also an effective "refueling" mode for the BEVs. Tesla Motors once promoted the battery swap technology in Los Angeles in 2013 to demonstrate that the replacement of the Model S battery is faster and more convenient than it is to fill a gas tank in the conventional vehicle. ${ }^{* *}$ There are some advantages for the battery swapping. Advantages include (a) battery swapping takes only 2-3 minutes in the station, which is faster than "refueling" through the electrical charging outlets or even faster than refueling the gas tank; (b) charging batteries in the swap stations makes good use of electricity between on-peak and off-peak, which contributes to energy saving; (c) the replaceable batteries can receive professional maintenance in the swap stations, which increases the battery lifetime and reliability; and (d) the battery rental for BEVs is a flexible business model for battery swap stations. In China, this "refueling" mode has been put into

\footnotetext{
*Yan Zhou. Argonne National Laboratory 2016. http://www.anl.gov/energy-systems/project/light-duty-electric-drive-vehiclesmonthly-sales-updates

† Source by the Toyota Motor Corp., "2016 Mirai Product Information", https://pressroom.toyota.com/releases/2016+toyota+mirai+fuel+cell+product.download (visited in September 2016)

$\$$ Green Car Congress, 2014. "Toyota FCV Mirai launches in LA; initial TFCS specs; $\$ 57,500$ or \$499 lease; leaning on Prius analogy", http://www.greencarcongress.com/2014/11/20141118-mirai.html (visited in September 2016)

$\S$ Source by http://www.cae.cn/cae/html/files/2015-10/29/20151029105822561730637.pdf (in Chinese)

** Tesla Motors Team, 2014. "Battery Swap Pilot Program”, https://www.teslamotors.com/blog/battery-swap-pilot-program
} 
practice by the Lifan Group in Chongqing, and by the BAIC and Sinopec in Beijing, and others." + Currently, Lifan Group has plans to invest ¥3 billion CNY (\$462 million USD) in the battery swap stations and these types of BEVs. ${ }^{\ddagger}$ Most of these battery swap BEVs are demonstrated by the public transit/taxi/government vehicles in Chongqing. Although the popularization of this promotional model to the individual consumers still needs more time, it is worthy to demonstrate for BEV's commercialization. However, because of the lack of unified standards for EV batteries and charging, the battery swap mode will face great difficulties when the government loses the interest.

\subsubsection{Vehicular telematics}

Based on the 2012-2020 China Intelligent Transportation Development Strategy (2012-2020 年中国智能 交通发展战) issued by the Ministry of Transport of China in 2012, China will build an intelligent transportation system to satisfy the requirements of future transportation industry by 2020 . Combining with the automotive control/monitoring system and the information communication/big data analysis, the vehicular telematics is becoming an investment hot spot in the Chinese vehicle market. Fig. 40 shows the expectations for the vehicular telematics systems by the Chinese drivers. The vehicular telematics are known by most ordinary drivers to be used for the automotive components maintenance and navigation, meanwhile vehicular telematics have already extended to every detail in the car, including the intelligent safety system, driving assistance, entertainment and communication, energy consumption reduction, and component maintenance.

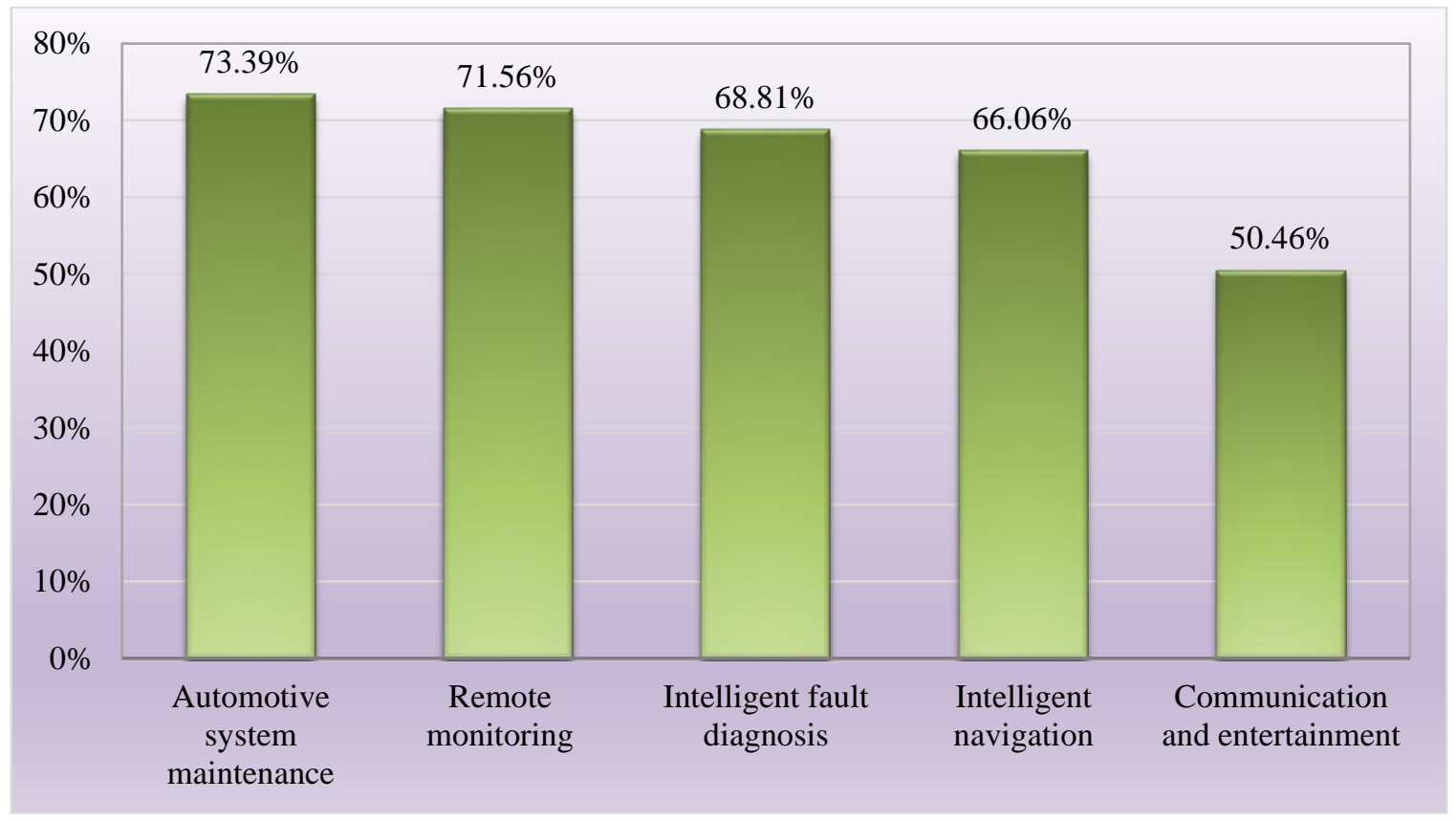

Fig. 40. Chinese consumer demands in vehicular telematics system. ${ }^{\S}$

\footnotetext{
*IHS Technology, 2015. "Lifan to invest USD 490 million in EVs, battery-swap stations", https://technology.ihs.com/531842/news-lifan-to-invest-usd490-million-in-evs-battery-swap-stations

$\dagger$ SINOPEC, 2015. "Sinopec Beijing Oil Products Company Builds EV Battery Charging/Replacement Stations with BAIC" http://www.sinopecgroup.com/group/en/Sinopecnews/20150715/news_20150715_627677447585.shtml

¥IHS Technology, 2015. "Lifan to invest USD 490 million in EVs, battery-swap stations",

https://technology.ihs.com/531842/news-lifan-to-invest-usd490-million-in-evs-battery-swap-stations

§ Sootoo, 2014. “2014 Chinese Telematics Market Analysis Report”, http://www.sootoo.com/content/514927.shtml (In Chinese)
} 
Due to the intense competition in the PEV market, a pleasant driving experience with the vehicular telematics in PEVs has become an essential vehicle feature to attract the consumers. With the capabilities of the telematics and intelligent technologies for vehicles, the information technology (IT) companies have been investing in the PEV industry. In U.S. market, Google and Apple, respectively, have their plans in producing BEVs or autonomous vehicles. ${ }^{*}+$ In China, the Chinese IT companies have entered this field to share in the wealth as well. In 2014, the LeTV which is China's Netflix, invested in the Atieva which is a famous U.S. electric vehicle design company in Silicon Valley. This purchase shows that the LeTV has started expanding its business into BEVs. ${ }^{\ddagger}$ In addition, in February 2016, the LeTV announced that it is cooperating with the Aston Martin to develop an intelligent EV named RapidE and expects to bring it to market by $2018 .^{\S}$ The Chinese IT company Baidu and Huawei have agreed with Audi to cooperate in CarLife (similar to Apply CarPlay, which is an intelligent control system in car) which will be equipped in Audi's cars for integrating a driver's smartphone to the car* ${ }^{*}$. Alibaba, one of the largest IT enterprises in China, has signed a strategic cooperative agreement with the SAIC Motor to produce PEVs equipped with its vehicular telematics technology. ${ }^{\dagger \dagger}$ Tencent (one of the largest IT company in China) parterned with the Foxconn (the largest electronic products supplier in the world) to invest $¥ 13.3$ billion CNY (\$2.04 billion USD) into their joint venture on EV batteries, EV manufacturing October $2016^{\$ 4}$. With the IT companies' participation, it is expected that PEVs will integrate more vehicular telematics technologies, which will be a significant derivative market in this industry.

\footnotetext{
* Philip Elmer-DeWitt. Fortune, 2015. "Apple and Google Expected to Lead Electric Car Race", http://fortune.com/2015/11/23/google-apple-virtual-reality-autonomous/ (visited in September 2016)

${ }^{\dagger}$ Daisuke Wakabayashi. The Wall Street Journal, 2015. “Apple Targets Electric-Car Shipping Date for 2019”, http://www.wsj.com/articles/apple-speeds-up-electric-car-work-1442857105 (visited in September 2016)

¥Fred Lambert. Electrek, 2015. "China’s Netflix, LeTV, Is Seriously Investing in Electric Vehicles", http://electrek.co/2015/08/31/chinas-netflix-letv-is-seriously-investing-in-electric-vehicles/ (visited in September 2016) $\S$ Aston Martin, 2016. “Aston Martin And LeEco Partner To Co-develop Electric Vehicle”, https://www.astonmartin.com/en/media-centre/press-releases/2016/02/17/aston-martin-and-leeco-partner-to-co-develop-electricvehicle (visited in September 2016)

${ }^{* *}$ Audi Media Center 2015. "AUDI AG Concluding Extensive Cooperation Agreements with Baidu and Huawei” https://www.audi-mediacenter.com/en/press-releases/audi-ag-concluding-extensive-cooperation-agreements-with-baidu-andhuawei-3680 (visited in September 2016)

$\dagger^{\dagger}$ SAIC Motor, 2015. "SAIC and Alibaba initiate \$161m fund for 'Internet cars", http://www.saicgroup.com/english/latest_news/saic_motor/37969.shtml (visited in September 2016)

\$ Phoenix Kwong. South China Morning Post, 2016. "Tencent's electric car unit to partner in 13.3bn yuan venture to build green vehicles in Jiangxi province" http://www.scmp.com/business/companies/article/2042024/tencents-electric-car-unit-partner133 bn-yuan-venture-build-green (visited in November 2016)
} 


\section{PLUG-IN ELECTRIC VEHICLE CONSUMER BEHAVIORS IN CHINA}

\subsection{PEV PURCHASE INTENTIONS}

The examination of PEV consumers or potential PEV buyer preferences is significant information to offer for catering the consumer demands in the PEV market in China. Moreover, the analysis of the characteristics of the Chinese consumers such as driving behaviors, demographic statistics, would be beneficial to the design of the appropriate PEVs for the appropriate groups. For example, the dense population in Chinese metropolises might result in a shorter average daily commute distance when comparing it with that in the U.S. shorter average daily commuting which contributes to PEV purchases with less electric driving range as they will be more acceptable for consumers in China. The PEV designer might choose the batteries with smaller capacity in the vehicle that will reduce the battery cost which is a significant proportion of the total vehicle cost. Of course, more factors need to be considered in vehicle design, but this example is fair enough to illustrate how important the PEV consumer's research is for PEV's commercialization.

Generally, PEV purchase intentions are classified into three categories:

- Economic benefits. Fuel consumption efficiency and government subsidies are attractive to the consumers who are sensitive to the vehicle prices (20-22). Moreover, other benefits from the nonmonetary incentives would also be essential to the PEV consumers. For example, travel time savings: PEVs are allowed single-occupant use of high occupancy vehicle (HOV) lanes which saves travel time in peak hours. Money saving: PEVs park free in municipal parking lots which saves money and time when looking for available parking space.

The economic benefits are magnified with the government stimulus in China. The PEVs have priority for applying for the vehicle registration and plate in the metropolitan cities such as Beijing or Shanghai, which is attractive to potential vehicle buyers in these cities.

- Symbolic meaning of the PEVs. The PEVs are generally regarded as environmentally friendly, and unique compared with the conventional vehicles (23). A PEV buyer can convey her/his support to environmental protection or her/his distinctive green life style. The "green" concepts of PEVs has been deeply embedded into consumers' thoughts, whether the well-to-wheel energy use and GHG in a PEV are less or not is still disputable (24).

- The positive attitude in acceptance of the new technology in automobiles (20). Commonly, a popular PEV packs plenty of technology breakthroughs such as the energy management system, intelligent control, driving assistance/self-driving, onboard internet/WIFI connectivity or entertainment media, etc. Especially when more and more IT companies participate in this industry, the new PEV products are frequently eye-catching to people. For example, Tesla has already become a maverick car brand in the automotive world. Tesla has its own marketing methods, design philosophy, and manufacturing technologies, which overturned the business model of the traditional automotive manufacturers.

\subsection{INVESTIGATING CHINA'S PEV MARKET}

Consumer research in the Chinese PEV market has been conducted by a few institutes. For instance, Helveston et al. investigated and compared consumer preference in both China and the U.S. using data from choice-based conjoint surveys in 2012-2013 (25). In this investigation, Helveston et al. conducted the survey in four Chinese cities (Beijing, Shanghai, Shenzhen, and Chengdu) and the survey focused on the high-income class from these cities. The study compared the attitudes of Chinese consumers and U.S. consumers, and concluded that the U.S. car owners viewed the PEVs as a high-status symbol while the 
Chinese respondents deemed the PEVs as nothing else but ordinary cars. The Chinese respondents were more sensitive to the operational cost even though they have higher incomes and good educational backgrounds (26). The CATARC also investigated the potential PEV consumer's demands yearly in most major cities in China. According to the investigation by CATARC, the biggest concerns by the target consumers of PEVs are the electric driving range, vehicle performance, price, charging time, and safety. About $71 \%$ of the target consumers believed that a $300 \mathrm{~km}$ (186 miles) electric driving range would satisfy them, and $90 \%$ of the target consumers preferred the maximum speed of a PEV over $140 \mathrm{~km} / \mathrm{h}(87$ $\mathrm{mph})$.

The consumer preference analysis supplies the policy makers reference on the PEV subsidy. Per the investigation by the Innovation Center for Energy and Transportation (iCET), the willingness to pay for a $\mathrm{HEV}$ is much higher compared with a PHEV or a BEV. This research showed that the HEV is a more favorable vehicle type for the Chinese respondents than PHEV/BEV, with the acceptance of the PHEV being much higher than the BEV (27). This study offered quantitative analysis for PEVs with the subsidies. The respondents are willing to pay $¥ 10,000 \mathrm{CNY}(\$ 1,541)$ more for a PHEV rated for $30 \mathrm{~km}$ electric driving range or $¥ 25,000 \mathrm{CNY}(\$ 3,853)$ more for a PHEV with a $60 \mathrm{~km}$ driving range when compared with the conventional cars. While a PHEV rated for $15 \mathrm{~km}$ electric driving range is expected to be sold out when $¥ 20,000 \mathrm{CNY}(\$ 3,082)$ are subsided by the government. However, most of the respondents in this investigation are from high income groups with better educational backgrounds, and they are inclined to accept the green, high-tech concepts in automobiles. Plus, all the investigation respondents for this investigation are from Chinese first-tier cities, where the PEV market and supporting facilities are well developed. Therefore, respondents from other regions are needed for a reliable conclusion nationally.

Some consumer investigation studies have been conducted on the PEV promotion technologies in some Chinese cities. For instance, the acceptance of EV battery swap services (BSS) is investigated (28) by Wang et al. in 2012. More than 1,000 questionnaires were circulated in four megacities (Beijing, Shanghai, Shenzhen and Chongqing) which revealed that the consumer acceptance for the BSS technology is more than $80 \%$ in the metropolises in China. Through sensitivity analysis, the investigation recognized that the features of BSS and battery swapping EVs, such as long battery life and recharge time savings and convenience, positively affect the acceptance percentage from individual consumers and are essential for BSS in the cities. However, most battery swapping BEVs are operating in public fleets (transits, taxis or sanitation vehicles), which is due to government procurement instead of the individual buyer market. Therefore, the high acceptance of the BSS is not necessarily to be regarded as a high purchase possibility by individuals.

Moreover, some surveys have been conducted in some specific cities for local resident's preference in the PEVs. By evaluating the responses from the PEV test drivers in Shanghai (26), the Fu et al., survey gave feature descriptions to the potential PEV buyers in Shanghai. These potential consumers already had cars and traveled more than $10 \mathrm{~km}$ (6.2 miles) to work. Their expected vehicle speed is 60 to $80 \mathrm{~km} / \mathrm{h}$ and they are from middle or high income groups. In addition, this research presented the investigation of the respondent evaluations for six Chinese PEV models. The ratings for the PEV's auto-interior and appearance design is poor compared to the conventional cars in the same class, but the respondents are more tolerant to the comfort of the PEV compared with their attitudes to the conventional cars of the same class.

A research report by the China Jiliang University presented the research for the PEV purchase plans of the residents in Hangzhou (29). Hangzhou is located in the Yangtze River delta economic zone and is the capital of Zhejiang province (there are four large PEV OEMs based on sales in Zhejiang shown in Fig. 15). This research included the respondents from a wide spectrum of the society in Hangzhou. It showed that the residents in Hangzhou have little knowledge of PEVs or related incentives; meanwhile they were 
sensitive to the vehicle price and inclined to purchase low-priced PEVs. This report argued that the purchase intentions were not influenced by the educational background, basic knowledge of PEVs or the number of cars in the household. This conclusion is different from the viewpoint by Helveston et al. 2015 or Fu et al. 2013 that found most potential PEV buyers have at least one car. This report fully investigated residents in Hangzhou from diverse social classes, and unfolded the societal perspectives to PEVs.

However, only $52.9 \%$ of the respondents had cars and $23.8 \%$ of the respondents had plans to buy a car, so not all the respondents in this report were potential PEV buyers. Nevertheless, a large-scale and systematic investigation has not been done in China yet, therefore it is hard to compare the pros and cons of the policies in the diverse regions and the influential factors on the Chinese potential PEV buyers are not clear yet. More research and new assessments are desperately needed for evaluating the new government incentives and regulations. 


\section{CONCLUSIONS}

China's PEV market has started booming after several rounds of incentives by the government. In 2015, China was the largest PEV market in the world, which increased $557 \%$ over 2014 and might have moved forward to the steep part of the S-curve in the market life cycle - a nascent growth phase. After low-cost placement or differentiation in the emergent phase of the PEV market in China, the massive PEV sales, sustainable increase of the competitors, the growth of PEV models targeted at individual consumers, and the acceptable PEV prices with subsidies probably hint that the Chinese PEV market has entered a nascent growth phase when the innovation, manufacturing process, delivery and aftermarket service matter most for competitors to differentiate from other firms.

The sustainable growth of PEV sales, the characteristics of the PEV market and structure, the attitudes from the policy makers and consumers, and the development of the PEV technologies in China are all valuable and inevitable concerns for various stakeholders from government, automakers, and academic analysts, and so forth. This report generally reviewed the Chinese PEV market including market structure, government policies, PEV technologies and infrastructure development, and several PEV consumer research studies. Major observations of the Chinese PEV market are summarized below:

- The PEV market in China is in a nascent growth phase and low concentrated, that new entrants are flooding into this industry, and most of their products are at low-end segment.

- PEVs are sold more in larger cities with better economic development where offer preferable financial support, higher EV infrastructure availability, more business models, more effective marketing, and stricter vehicle purchase limitations. However, the regional trade protectionism might be an obstacle for PEV market expansion for automakers in other areas in China.

- Currently, the domestic private-owned automakers are one step ahead in the PEV market compared to the large domestic state-owned automakers, although the domestic state-owned auto firms still possess the competitive edge in the long-term with advantages in $\mathrm{R} \& \mathrm{D}$, investments, and government policies.

- The PEV segment is a more policy-driven market which is heavily impacted by the government incentives or related regulations. The policy makers are changing the monetary incentives to CAFC/NEV credits regulation during 2016-2020, which will reduce the government's fiscal burden. The government expects that the PEV stocks in China will reach 5 million by 2020.

- Unlike the consumers in the U.S. who viewed PEVs as a status symbol, the consumers in China bought PEVs based on realistic considerations, such as lower prices with abundant subsidies, vehicle driving limitations in megacities, and potential energy cost saving to name a few.

This report has qualitatively described the current state of the Chinese PEV market penetration. Through collaboration with the CATARC, the ORNL analyzed numerous features of the PEV sales market, consumer behaviors, PEV technologies, PEV infrastructure, and government incentives in the Chinese vehicle data. In the next study, the MA3T (Modeling the Market Acceptance of Advanced Automotive Technologies) developed by the ORNL will be applied to the Chinese PEV market for quantitative analysis of the vehicle market penetration, energy strategies and incentives assessments in China. 


\section{REFERENCES}

1. Zheng, J., S. Mehndiratta, J. Y. Guo, and Z. Liu. Strategic policies and demonstration program of electric vehicle in China. Transport Policy, Vol. 19, No. 1, 2012, pp. 17-25.

2. CATARC. Automotive Data Center Database of China Automotive Technology and Research Center. Tianjin China, 2016.

3. Cao, B., C. Yu, and J. Liao. Classification Standard for Passenger Car Company. Journal of Sichuan Ordnance, Vol. 34, No. 12, 2013, p. 4.

4. Howell, S., H. Lee, and A. Heal. Leapfrogging or Stalling Out? Electric Vehicles in China. Publication RWP14-035. HKS Working Paper, 2014.

5. China Automotive Dealers Association. U Trend of Vehicle Sales, Chinese brands are attractive in Chinese Vehicle Market (in Chinese). http://www.cada.cn/xinche/info_118_4189.html.

Accessed Jul. 18, 2016.

6. Gallagher, K. S. Foreign Technology in China's Automobile Industry: Implications for Energy, Economic Development, and Environment. China Environment Series, Vol. 6, 2003, pp. 1-18.

7. U.S. Department of Energy. Alternative Fuels and Advanced Vehicles Data Center. http://www.afdc.energy.gov/. Accessed Jul. 18, 2016.

8. Lin, Z. Optimizing and Diversifying Electric Vehicle Driving Range for US Drivers. Transportation Science, Vol. 48, No. 4, 2014, pp. 635-650.

9. Davis, S., S. E. Williams, R. G. Boundy, and S. Moore. 2015 Vehicle Technologies Market Report. Knoxville TN, 2015.

10. China Automotive Technology and Research Center, Nissan Group of China, and Dongfeng Motor Company. Annual Report on New Energy Vehicle Industry in China (2015). book. Social Sciences Academic Press, Beijing, China, 2015.

11. Li, Z., and L. Sun. The Impact of The Government Policy on The Chinese Electric Vehicle Industry and Business Strategy Management: Case of FAW. JOUR. Linköpings Universitet, 2011.

12. Yao, Y., and M. Di. Comparison of Passenger Vehicle Fuel Consumption Standards in USA, EU and Japan. Journal of Chongqing Jiaotong University (Natural Science), Vol. 30, No. 4, 2011, pp. 868-872.

13. Schoettle, B., and M. Sivak. A comparison of CAFE standards and actual CAFE performance of new light-duty vehicles. University of Michigan, Ann Arbor, Transportation Research Institute, 2013.

14. Nykvist, B., and M. Nilsson. Rapidly falling costs of battery packs for electric vehicles. Nature Climate Change, Vol. 5, No. 4, 2015, pp. 329-332.

15. Ngan, H. W. Electricity regulation and electricity market reforms in China. Energy Policy, Vol. 38, No. 5, 2010, pp. 2142-2148.

16. An, B., W. Lin, A. Zhou, and W. Zhou. China's Market-Oriented Reforms in the Energy and Environmental Sectors. Beijing, China, 2015.

17. Klebanoff, L. Hydrogen storage technology: materials and applications. book. CRC Press, 2012.

18. Yoshida, T., and K. Kojima. Toyota MIRAI Fuel Cell Vehicle and Progress Toward a Future Hydrogen Society. The Electrochemical Society Interface, Vol. 24, No. 2, 2015, pp. 45-49.

19. Yamashita, A., M. Kondo, S. Goto, and N. Ogami. Development of High-Pressure Hydrogen Storage System for the Toyota " Mirai .” 2016.

20. Turrentine, S. T., R. R. Heffner, and S. K. Kurani. Symbolism and the adoption of fuel-cells vehicles. The World Electric Vehicle Association Journal, Vol. 1, 2007, pp. 24-31.

21. Heffner, R. R., K. S. Kurani, and T. S. Turrentine. Symbolism in California's early market for hybrid electric vehicles. Transportation Research Part D: Transport and Environment, Vol. 12, No. 6, 2007, pp. 396-413.

22. Gallagher, K. S., and E. Muehlegger. Giving green to get green? Incentives and consumer adoption of hybrid vehicle technology. Journal of Environmental Economics and Management, 
Vol. 61, No. 1, 2011, pp. 1-15.

23. Klein, J. Why people really buy hybrids. Topline Strategy Group.[online] Available, 2007.

24. Elgowainy, A., J. Han, L. Poch, M. Wang, A. Vyas, M. Mahalik, and A. Rousseau. Well-towheels analysis of energy use and greenhouse gas emissions of plug-in hybrid electric vehicles. Argonne National Laboratory (ANL), Lemont, IL, 2010.

25. Helveston, J. P., Y. Liu, E. M. Feit, E. Fuchs, E. Klampfl, and J. J. Michalek. Will Subsidies Drive Electric Vehicle Adoption? Measuring Consumer Preferences in The U.S. and China. Transportation Research Part A: Policy and Practice, Vol. 73, 2015, pp. 96-112.

26. Fu, G., X. Wu, M. Zhou, H. Shi, and J. Wang. Evaluations and purchase intentions by EV test drivers. Journal of Automotive Safety and Energy, Vol. 4, No. 3, 2013, p. 6.

27. Innovation Center For Energy And Transportation. China Consumer EV Choice Preference Study Brief. Beijing China, 2016.

28. Wang, H., H. Song, and M. Ouyang. Impact factor analysis of the consumer acceptance of electric vehicle battery swapping service (in Chinese). Journal of Automotive Safety and Energy, Vol. 3, No. 1, 2012, p. 7.

29. Meng, L., Z. Huang, X. Guo, B. Zhang, and W. Zhu. Project Report of Hangzhou Residents New Energy Vehicle Purchase Intention and Its Influence Factors (in Chinese). Hangzhou China, 2012. 
APPENDIX A. MAJOR NATIONAL POLICIES OR EVENTS IN PEV INDUSTRY, 2001-2015 



\section{APPENDIX A. APPENDIX A. MAJOR NATIONAL POLICIES OR EVENTS IN PEV INDUSTRY, 2001-2015}

\begin{tabular}{|c|c|c|}
\hline Date & Major policies or events & $\begin{array}{l}\text { Description in PEV } \\
\text { Industry }\end{array}$ \\
\hline $03 / 2001$ & Tenth Five-Year Plan (2001-2005)* & $\begin{array}{l}\text { Encourage new energy } \\
\text { vehicle R\&D. }\end{array}$ \\
\hline $05 / 2004$ & Auto Industry Development Policy ${ }^{\dagger}$ & $\begin{array}{l}\text { Prioritize hybrid tech, } \\
\text { encourage other PEV } \\
\text { development. }\end{array}$ \\
\hline $02 / 2005$ & $\begin{array}{l}\text { China Medium and Long-Term Science and Technology } \\
\text { Planning }(2006 \sim 2020)^{\ddagger}\end{array}$ & $\begin{array}{l}\text { Prioritize hybrid vehicles, } \\
\text { and other alternative fuels } \\
\text { vehicles development. }\end{array}$ \\
\hline 03/2006 & $\begin{array}{l}\text { Eleventh Five-Year Plan on Energy-Saving and New Energy } \\
\text { Vehicle Project }\end{array}$ & $\begin{array}{l}\text { Promote PEV } \\
\text { industrialization. }\end{array}$ \\
\hline $10 / 2007$ & $\begin{array}{l}\text { Rules on the Production Admission Administration of New } \\
\text { Energy Automobiles }(2007)^{\S}\end{array}$ & $\begin{array}{l}\text { Create rules for PEV } \\
\text { manufacturing and sales }\end{array}$ \\
\hline $01 / 2009$ & $\begin{array}{l}\text { Ten Cities and Thousands Energy-Saving \& New Energy } \\
\text { Vehicles Demonstration Application Project }\end{array}$ & $\begin{array}{l}\text { Promote the PEV } \\
\text { demonstration running by } \\
\text { subsidies. (Only } 38 \% \\
\text { goals were achieved after } \\
3 \text { years) }\end{array}$ \\
\hline $03 / 2009$ & Plan on Adjusting and Revitalizing the Auto Industry ${ }^{* *}$ & $\begin{array}{l}\text { Expect } 500,000 \text { unites } \\
\text { HEV/PEVs by } 2011\end{array}$ \\
\hline $10 / 2010$ & $\begin{array}{l}\text { Decision of the State Council on Accelerating the Fostering } \\
\text { and Development of Strategic Emerging Industries }{ }^{\dagger \dagger}\end{array}$ & $\begin{array}{l}\text { PEV is emphasized as one } \\
\text { of strategic emerging } \\
\text { industries }\end{array}$ \\
\hline $09 / 2011$ & $\begin{array}{l}\text { Specialized Planning on Electric Vehicle Technology } \\
\text { Development in "Twelfth Five-year Plan" } \$\end{array}$ & $\begin{array}{l}\text { Make specific goals on } \\
\text { PEV industry and PEV } \\
\text { component technology }\end{array}$ \\
\hline $01 / 2012$ & $\begin{array}{l}\text { Notice of the Ministry of Finance, State Administration of } \\
\text { Taxation, and Ministry of Industry and Information } \\
\text { Technology on Vehicle and Vessel Tax Policies for Energy- } \\
\text { Efficient or New Energy Vehicles and Vessels }\end{array}$ & $\begin{array}{l}\text { Tax credits and financial } \\
\text { subsidies for PEV owners }\end{array}$ \\
\hline $06 / 2012$ & $\begin{array}{l}\text { Planning for the Development of the Energy-Saving and } \\
\text { New Energy Automobile Industry }(2012-2020)^{* * *}\end{array}$ & $\begin{array}{l}\text { Government guideline } \\
\text { document in PEV }\end{array}$ \\
\hline $02 / 2012$ & Notice of Better Promoting New Energy Vehicles ${ }^{\dagger \dagger \dagger}$ & $\begin{array}{l}\text { The subsidies in } 2014 \text { on } \\
\text { PEV became less } \\
\text { compared with } 2013 \text {. }\end{array}$ \\
\hline
\end{tabular}

\footnotetext{
${ }^{*}$ Source by http://www.sdpc.gov.cn/fzgggz/fzgh/ghwb/gjjh/200709/P020070912638583847233.pdf (in Chinese)

$\dagger$ Source by http://www.cecc.gov/resources/legal-provisions/auto-industry-development-policy (in Chinese)

\$ Source by http://www.most.gov.cn/kjgh/kjghzcq/ (in Chinese)

$\S$ Source by http://bgt.ndrc.gov.cn/zcfb/200710/W020120821510838477603.pdf (in Chinese)

*** Source by http://www.gov.cn/zwgk/2009-03/20/content 1264324.htm (in Chinese)

i† Source by http://www.gov.cn/zwgk/2010-10/18/content_1724848.htm (in Chinese)

\# Source by http://www.chinaev.org/DisplayView/Vip/Policy/PolicyDetail.aspx?id=663 (in Chinese)

$\S \S$ Source by http://www.chinatax.gov.cn/n810341/n810765/n812151/n812426/c1083813/content.html (in Chinese)

${ }^{* * * *}$ Source by http://www.ycdpc.gov.cn/ywgl/gyfz/201204/W020120508580846293516.pdf (in Chinese)

ti Source by http://www.most.gov.cn/tztg/201402/t20140212_111801.htm (in Chinese)
} 


\begin{tabular}{|c|c|c|}
\hline Date & Major policies or events & $\begin{array}{l}\text { Description in PEV } \\
\text { Industry }\end{array}$ \\
\hline $05 / 2014$ & China EVI00 was established & $\begin{array}{l}\text { It is a first think tank on } \\
\text { Chinese auto industry. }\end{array}$ \\
\hline $07 / 2014$ & $\begin{array}{l}\text { Accelerating the Promotion and Application of New-energy } \\
\text { Automobiles" }\end{array}$ & $\begin{array}{l}\text { Government guideline } \\
\text { document in PEV; Expect } \\
\text { to build related } \\
\text { infrastructure for PEV. }\end{array}$ \\
\hline $07 / 2014$ & $\begin{array}{l}\text { Implementation Plan on New Energy Vehicle Purchase for } \\
\text { Government/Public Institutes }{ }^{\dagger}\end{array}$ & $\begin{array}{l}\text { PEV numbers should not } \\
\text { less than } 30 \% \text { of new } \\
\text { vehicles. }\end{array}$ \\
\hline $08 / 2014$ & $\begin{array}{l}\text { Announcement on the Exemption of Vehicle Purchase Tax on } \\
\text { New Energy Vehicles }\end{array}$ & $\begin{array}{l}\text { Tax incentives for PEV } \\
\text { purchasing }\end{array}$ \\
\hline $11 / 2014$ & $\begin{array}{l}\text { Notice of Subsidy for Charging Infrastructure } \\
\text { Constructions } \$\end{array}$ & $\begin{array}{l}\text { Subsides for the charging } \\
\text { infrastructure }\end{array}$ \\
\hline $04 / 2015$ & $\begin{array}{l}\text { Financial Support Policies on the Promotion and } \\
\text { Application of New Energy Vehicles (2016-2020) }\end{array}$ & $\begin{array}{l}\text { The subsidy incentives } \\
\text { will be withdrawn since } \\
2016 \text { to } 2020\end{array}$ \\
\hline $05 / 2015$ & Made in China $2025^{\dagger \dagger}$ & $\begin{array}{l}\text { Government guideline } \\
\text { document in PEV }\end{array}$ \\
\hline $07 / 2015$ & $\begin{array}{l}\text { Provisions on the Administration of Newly Established Pure } \\
\text { Electric Passenger Vehicle Enterprises }\end{array}$ & $\begin{array}{l}\text { Encourage small } \\
\text { manufacturers become } \\
\text { qualified PEV providers }\end{array}$ \\
\hline $09 / 2015$ & $\begin{array}{l}\text { Guiding Opinions on Accelerating the Construction of } \\
\text { Electric Vehicle Charging Infrastructure } \\
\S \S\end{array}$ & $\begin{array}{l}\text { Encourage and planning } \\
\text { the construction of } \\
\text { charging infrastructure }\end{array}$ \\
\hline $12 / 2015$ & New Vehicle Charging National Standards was carried out & $\begin{array}{l}\text { The new standards will } \\
\text { help the PEV promotions }\end{array}$ \\
\hline
\end{tabular}

\footnotetext{
* Source by http://www.gov.cn/zhengce/content/2014-07/21/content_8936.htm (in Chinese)

${ }^{\dagger}$ Source by http://www.ggj.gov.cn/zcfg/zcfgggjgjn/201407/t20140711_286066.htm (in Chinese)

* Source by http://szs.mof.gov.cn/zhengwuxinxi/zhengcefabu/201408/t20140806_1123100.html (in Chinese)

${ }^{\S}$ Source by http://jjs.mof.gov.cn/zhengwuxinxi/tongzhigonggao/201411/t20141125_1160262.html (in Chinese)

${ }^{* *}$ Source by http://www.miit.gov.cn/n11293472/n11293832/n11293907/n11368223/16567545.html (in Chinese)

${ }^{\dagger}$ Source by http://www.gov.cn/zhengce/content/2015-05/19/content_9784.htm (in Chinese)

* Source by http://www.vecc-mep.org.cn/download/diandongche.pdf (in Chinese)

$\S \S$ Source by http://www.sdpc.gov.cn/zcfb/zcfbtz/201511/W020151117576336784393.pdf (in Chinese)
} 